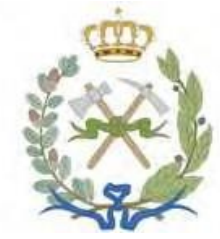

ESCUELA TÉCNICA SUPERIOR DE INGENIEROS DE MONTES, FORESTAL Y DEL MEDIO NATURAL

\title{
INPUT-OUTPUT ANALYSIS FOR THE QUANTIFICATION OF THE ENVIRONMENTAL FOOTPRINT. CASE STUDIES IN SPAIN
}

TESIS DOCTORAL

SARA MARTÍNEZ DELGADO

Ingeniero Agrónomo

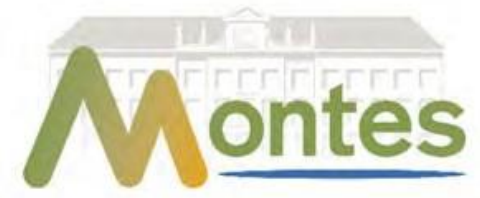

MADRID, 2019 
PROGRAMA DE DOCTORADO EN INVESTIGACIÓN FORESTAL AVANZADA

ESCUELA TÉCNICA SUPERIOR DE INGENIEROS DE MONTES, FORESTAL Y DEL MEDIO NATURAL

UNIVERSIDAD POLITÉCNICA DE MADRID

\title{
INPUT-OUTPUT ANALYSIS FOR THE QUANTIFICATION OF THE ENVIRONMENTAL FOOTPRINT. CASE STUDIES IN SPAIN
}

\author{
Autor \\ SARA MARTÍNEZ DELGADO \\ Ingeniero Agrónomo \\ Director \\ SERGIO ÁLVAREZ GALLEGO \\ Doctor Ingeniero de Montes
}

MADRID, 2019 
Tribunal nombrado por el Magfco. y Excmo. Sr. Rector de la Universidad Politécnica de Madrid, el día de

\begin{tabular}{|c|c|}
\hline Presidente/a & 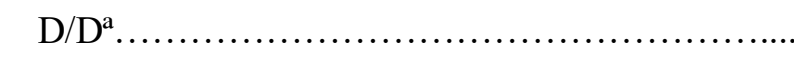 \\
\hline Vocal & $\mathrm{D} / \mathrm{D}^{\mathrm{a}}$. \\
\hline Vocal & $\mathrm{D} / \mathrm{D}^{\mathrm{a}}$. \\
\hline Vocal & $\mathrm{D} / \mathrm{D}^{\mathrm{a}}$. \\
\hline Secretario/a & $\mathrm{D} / \mathrm{D}^{\mathrm{a}}$. \\
\hline Suplente & $\mathrm{D} / \mathrm{D}^{\mathrm{a}} \ldots$ \\
\hline Suplente & $\mathrm{D} / \mathrm{D}^{\mathrm{a}}$. \\
\hline
\end{tabular}

Realizado el acto de defensa y lectura de la Tesis el día...... de de en la Escuela Técnica Superior de

Ingenieros de Montes, Forestal y del Medio Natural de la Universidad Politécnica de Madrid.

Calificación.

PRESIDENTE/A

VOCALES

SECRETARIO/A 

"Cuando llegue la inspiración, que me encuentre trabajando"

PABLO PICASSO

(1881-1973) 



\section{AGRADECIMIENTOS}

A menudo me gusta recordar la frase de Ortega y Gasset "Yo soy yo y mi circunstancia, y si no la salvo a ella no me salvo yo". Mis circunstancias me han traído hasta aquí, lo que empezó como algo complementario, espero que fructifique en algo mayor. De todas las experiencias que he vivido y de todas las personas que han compartido esta etapa de mi vida he aprendido algo constructivo. Ojalá tuviera todo el espacio del mundo para agradecerles y escribirles todo lo que han hecho por mí.

Desde el principio he tenido la suerte de trabajar con el extraordinario director de tesis y aún mejor persona, Sergio Álvarez. En primer lugar, gracias por haberme descubierto este tema de la Huella Ambiental que no sabía que me daría tantas alegrías. En segundo lugar, gracias por tu plena dedicación que ni la distancia ha sido capaz de impedir y por esas tardes hablando de la vida en general.

También me gustaría agradecer al Departamento de Ingeniería y Morfología del Terreno y, en especial a Miguel Marchamalo, el proporcionarme cobijo y hacerme sentir como en casa.

A Justo, Marisu, Aldara y Rober y a toda mi nueva familia en general, muchísimas gracias por acogerme tan bien y hacerme sentir como un miembro más de vosotros y bridarme vuestro apoyo.

Sin lugar a dudas, todo lo que soy se lo debo a mis padres, Rubén y María del Mar. Gracias de corazón, porque cada vez que hablamos me transmitís la fuerza para continuar. Sois mi referente a seguir y tenéis mi plena admiración. Mamá, gracias por tu cariño y amor. Papá, nunca vas a dejar de ser mi superhéroe. Vosotros me habéis enseñado a ser valiente y no tener miedo a los cambios. No hay palabras que puedan expresar lo que os quiero.

No me olvido de mis hermanos. Muchas gracias, Alberto y Mónica, por compartir 
vuestro tiempo conmigo y por aconsejarme. A ti también Carlos, que sean los actos los que demuestren mi aprecio hacia ti y que seamos capaces de apreciar lo que tenemos. Sería eterno si agradeciese a cada miembro de mi familia lo que ha hecho por mí, simplemente que sepáis que sois muy importantes en mi vida.

Este trabajo también os lo dedico a vosotros abuelos, que siempre me habéis apoyado. Abuelo, gracias por decir con orgullo que su nieta es ingeniero, que sepas que aún te admiro por tu capacidad de hacer cálculos más rápido que yo. Abuela, te echo de menos, y aunque no estés aquí, te quiero dedicar este trabajo. Gracias por encender una vela y pedir por mí. Estás conmigo en cada uno de mis logros.

Por último, me faltas tú, mi amigo, confidente, compañero de tesis, pero sobre todo mi acompañante de vida. Por escucharme, por consolarme en mis momentos bajos, por apoyarme y darme seguridad, por tu cariño y amor, porque sin ti nada sería igual, por todo y mucho más, muchísimas gracias Adri. Espero que sigamos evolucionando y reinventándonos juntos y compartiendo momentos felices.

En definitiva, gracias a todos, porque sé que donde quiera que vaya estaréis conmigo a cada paso que doy. 


\section{ABSTRACT}

Achieving sustainable development is the overarching goal of the current's policy framework. Among the three pillars for sustainability, managing the planet's natural resources is essential to promote environmental sustainability. In this sense, environmental accounting tools are needed to quantify and inform decision makers of potential environmental impacts and their implications. The Environmental Footprint (EF) has been proposed by the European Commission as a multi-criteria indicator to establish a common methodological approach to enable Member States and the private sector to assess, display and benchmark the environmental performance of products, services and companies based on a comprehensive assessment of environmental impacts over the life-cycle.

Traditionally, Life-Cycle Assessments (LCA) have been carried out applying the process-based method. However, in this highly globalized world, the need to quantify all the impacts generated along the entire supply chain has increased the application of the Environmentally-Extended Multi-Regional Input-Output (EEMRIO) method. This method enables the tackling of the environmental impacts generated along the supply chain, as well as, their linkages between economic sectors and regions.

The main objective of this research is to obtain the EF as a multi-criteria indicator quantified applying the EEMRIO method. To this end, the EF has been obtained for five case studies. The first three investigations refer to the three economic sectors. The primary sector is assessed by the calculation of the EF of an organic peri-urban orchard network, the secondary sector is evaluated by studying the EF of a company of wood parquet and the tertiary sector is assessed by obtaining the EF of a construction company carrying out a service of maintenance and conservation of a river. The fourth case study is based on the EF of the Spanish households' consumption and its effects on the imported goods. 
Finally, the fifth investigation is aimed at presenting a methodological advance by applying a hybrid-MRIO method to obtain the EF.

These case studies serve as the starting point to evidence the strengths of implementing such a valuable indicator to evaluate the environmental impacts and propose measures to reduce them. According to this research, the EEMRIO method serves as a useful tool, which allows the identification and quantification of the environmental impacts. The main conclusion is that the EF is a novel indicator capable of capturing the entire picture concerning the environmental impacts and that its quantification applying the EEMRIO method provides an in-depth assessment of the sectorial and regional linkages. Sustainable development requires the effort of all the sectors and population and the implementation of the EF could aid to achieve this goal. 


\section{RESUMEN}

Alcanzar un desarrollo sostenible es el objetivo principal del marco político actual. Entre los tres pilares de sostenibilidad, la gestión de los recursos naturales es esencial para promover la sostenibilidad ambiental. En este sentido, es necesario disponer de herramientas de contabilidad ambiental para cuantificar e informar a los responsables de adoptar decisiones de los potenciales impactos medioambientales y de sus implicaciones. La Comisión Europea ha propuesto la Huella Ambiental (HA) como un indicador multicriterio para establecer una metodología común que permita a los Estados miembros $\mathrm{y}$ al sector privado valorar, presentar y comparar el comportamiento medioambiental de productos, servicios y empresas basados en la evaluación de los impactos medioambientales a lo largo de todo el ciclo de vida.

El Análisis Ciclo de Vida ha sido tradicionalmente llevado a cabo aplicando el método conocido como análisis de procesos. Sin embargo, en este mundo altamente globalizado, la necesidad de cuantificar los impactos generados a lo largo de la cadena de producción ha aumentado el uso del método Input-Output multirregional con la extensión medioambiental. Este método permite abordar los impactos medioambientales generados a lo largo de toda la cadena de producción, así como, las conexiones entre sectores económicos y regiones.

El objetivo principal de esta tesis doctoral es el cálculo de la HA como indicador multicriterio aplicando el método Input-Output multirregional con la extensión medioambiental. Para ello, se ha analizado la HA en cinco casos de estudio. Las primeras tres investigaciones hacen referencia a los tres sectores económicos. La aplicación en el sector primario se ha realizado por medio del cálculo de la HA en una red de huertas orgánicas periurbanas, en el sector secundario se ha estudiado la HA de una empresa de manufactura de parquet de madera, y en el sector terciario se ha obtenido la HA de los 
servicios realizados por una empresa en el mantenimiento y conservación de un río. El cuarto caso de estudio está basado en la HA generada por el consumo de los hogares españoles y sus efectos medioambientales de las importaciones. Finalmente, la quinta investigación tiene como objetivo llevar a cabo un avance metodológico aplicando el método híbrido para obtener la HA.

Estos casos de estudio sirven como punto de partida para evidenciar las fortalezas de implementar este valioso indicador para evaluar los impactos medioambientales y proponer medidas para su reducción. De acuerdo a este estudio, el método Input-Output multirregional con la extensión medioambiental es una herramienta práctica y útil permitiendo identificar y cuantificar los impactos medioambientales. La conclusión principal es que la HA es un indicador innovador capaz de capturar los impactos medioambientales desde una perspectiva global y que su cuantificación aplicando el método propuesto proporciona un análisis detallado de las conexiones entre sectores y regiones. Alcanzar un desarrollo sostenible precisa del esfuerzo de todos los sectores económicos y de la población y la implementación de la HA puede ayudar alcanzar dicho objetivo. 


\section{ABBREVIATIONS}

EU: European Union

MDG: Millennium Development Goals

SDG: Sustainable Development Goals

LCA: Life Cycle Assessment

EF: Environmental Footprint

PEF: Product Environmental Footprint

OEF: Organization Environmental Footprint

PEFCR: Product Environmental Footprint Category Rule

OEFSR: Organization Environmental Footprint Category Rule

LCI: Life Cycle Inventory

ISO: International Organization for Standardization

IO: Input-Output

IOT: Input-Output Table

EEMRIO: Environmentally-Extended Multi-Regional Input-Output

MRIO: Multi-Regional Input-Output

EEIO: Environmentally-Extended Input-Output

IO-LCA: Input-Output Life Cycle Assessment

ILCD: International Reference Life Cycle Data System

SWOT: Strengths, Weaknesses, Opportunities and Threats

S-LCA: Social Life Cycle Assessment 



\section{INDEX}

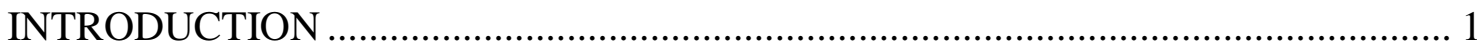

Global Environmental change and sustainable development .................................31.

1.1. Global Environmental change ............................................................... 3

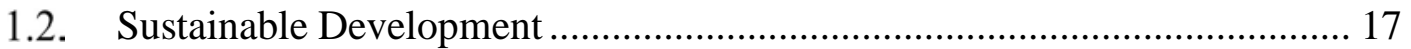

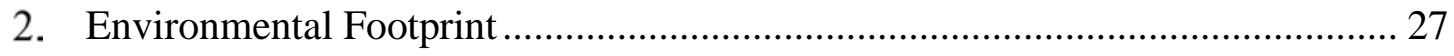

Context and types of Environmental Footprint .........................................272.1.

Environmental Footprint and Life Cycle Assessment ..................................302.2.

Science mapping on the Environmental Footprint ................................................403.

Bibliometric search and a scientometric analysis .......................................403.1.

Overview of the Environmental Footprint.................................................433.2.

Environmental Footprint and Life-Cycle Assessment analysis ....................503.3.

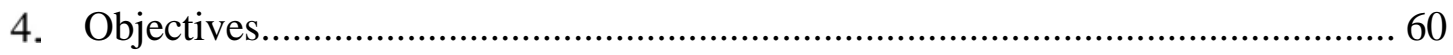

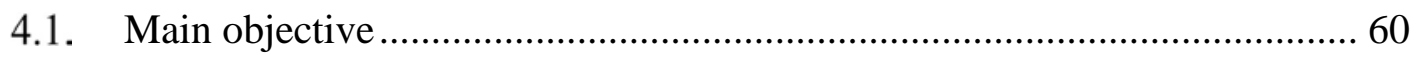

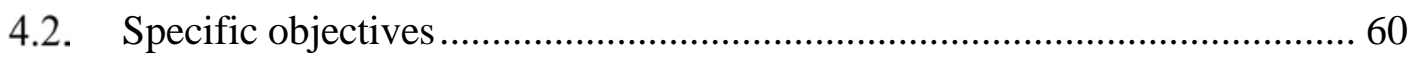

Chapters' description and justification .........................................................614.3.

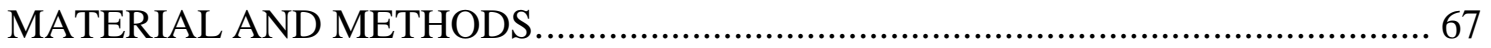

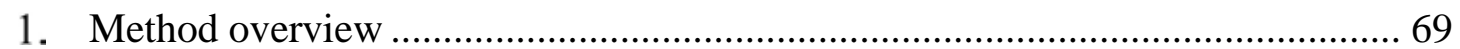

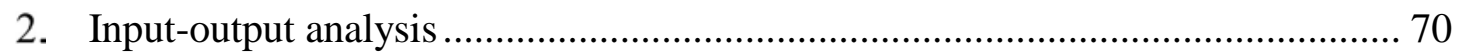

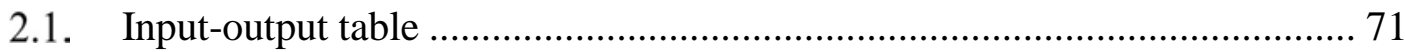

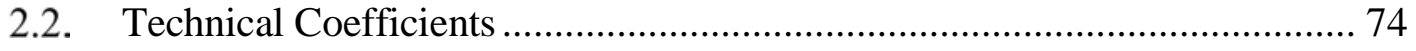

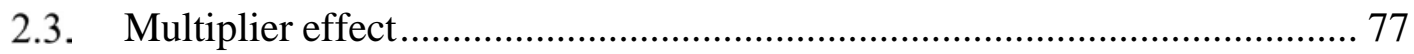

Environmentally-extended input-output analysis and Multi-regional environmentally-extended input-output analysis .....................................................793.

Environmentally-extended input-output analysis .......................................793.1.

Multi-regional environmentally-extended input-output analysis ...................813.2.

3.3. Multi-regional environmentally-extended input-output analysis .................. 83

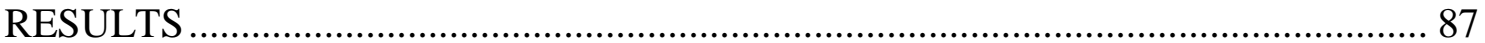

Primary sector: The Environmental Footprint of an organic peri-urban orchard network 891.

2. Secondary sector: Organization Environmental Footprint applying a multiregional input-output analysis: A case study of a wood parquet company in Spain .. 91

Tertiary sector: Organisation Environmental Footprint through input-output analysis. Case study in the construction sector

4. Household consumption: Environmental Footprint by source of supply chains 
Input-Output Analysis for the quantification of the Environmental Footprint. Case studies in Spain

from Spanish household consumption

5. Methodological advance: The Environmental Footprint of the end-of-life phase of a dam through a hybrid-MRIO analysis

DISCUSSION

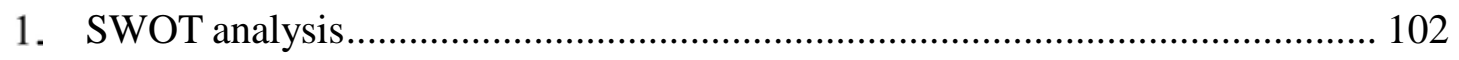

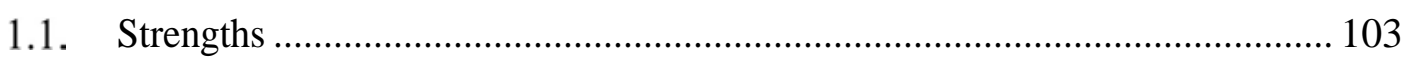

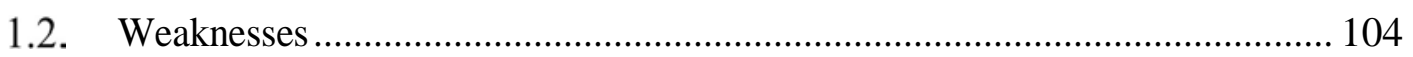

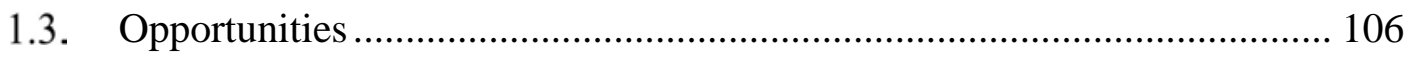

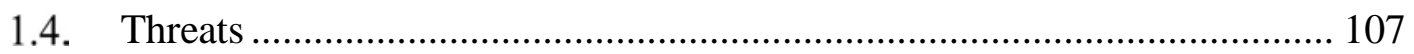

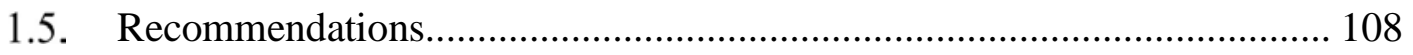

Limitations and benefits of the environmentally-extended multi-regional inputoutput analysis

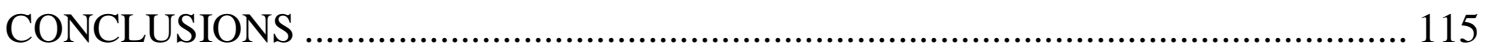

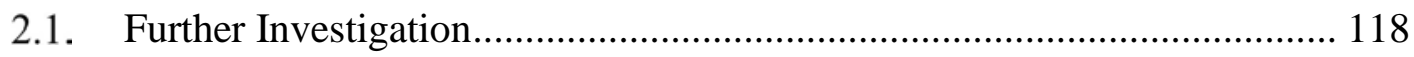

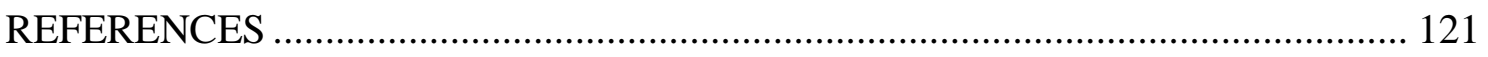

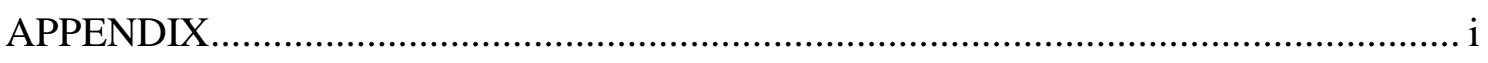

Appendix 1: The Environmental Footprint of an organic peri-urban orchard network .. iii Appendix 2: Organization Environmental Footprint applying a multi-regional inputoutput analysis: A case study of a wood parquet company in Spain ............................. XV

Appendix 3: Organisation Environmental Footprint through input-output analysis. Case

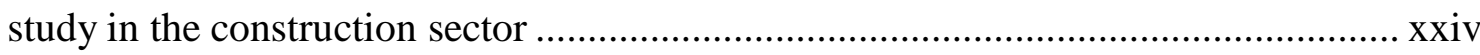

Appendix 4: Environmental Footprint by source of supply chains from Spanish household consumption xlvi

Appendix 5: The Environmental Footprint of the end-of-life phase of a dam through a hybrid-MRIO analysis lxxiv 


\section{FIGURE INDEX}

Figure 1. Human impacts estimated by means of three aspects, population, affluence and technology 6

Figure 2. Estimate of quantitative evolution of control variables for seven planetary boundaries from preindustrial levels to 2009

Figure 3. Temperature and stability comparison between the Holocene and the Anthropocene.

Figure 4. Visual Representations of Sustainable Development: (a) separated, (b) pillars, (c) concentric circles, (d) overlapping circles. 19

Figure 5. Sustainable Development Goals adopted by the United Nations. 22

Figure 6. Scorecard of the selected target per goal ................................................ 23

Figure 7. Environmental Footprint boundaries and impacts................................ 31

Figure 8. Process overview for Environmental Footprint Studies.......................... 34

Figure 9. Environmental Footprint approaches regarding system boundaries........ 34

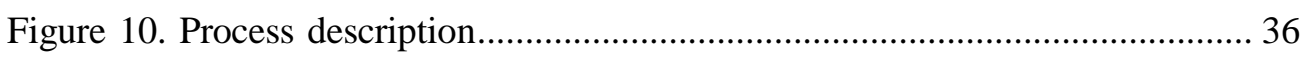

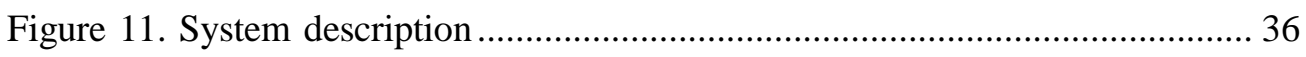

Figure 12. Number of publications per year in the Environmental Footprint field from 1999 to 2018 . 44

Figure 13. Number of citations per year in the Environmental Footprint field from 1999 to 2018. 44

Figure 14. Environmental Footprint document co-citation network ..................... 46

Figure 15. Mapping of keywords in the Environmental Footprint domain............ 49

Figure 16. Distribution of the types of documents the Environmental Footprint and Life Cycle Assessment field from 2000 to 2018 .................................................... 52

Figure 17. Environmental Footprint and Life Cycle Assessment document cocitation network

Figure 18. Mapping of keywords in the Environmental Footprint and Life Cycle Assessment domain.

Figure 19. Mapping of journal sources in the Environmental Footprint and Life Cycle Assessment domain.

Figure 20. Mapping of countries in the Environmental Footprint and Life Cycle Assessment domain. 
Input-Output Analysis for the quantification of the Environmental Footprint. Case studies in Spain

Figure 21. The Environmental Footprint's Strengths-Weaknesses-Opportunities-

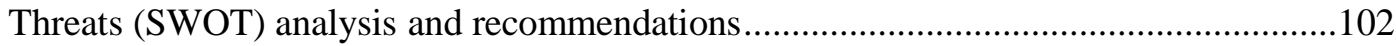

Figure 22. Hotspot analysis in the Environmental Footprint initiative ...................104

Figure 23.The environmental-extended multi-regional input-output (EEMRIO)

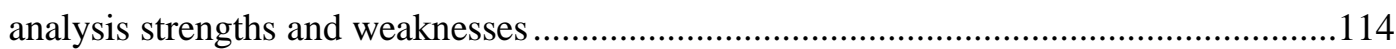




\section{TABLE INDEX}

Table 1. Impact categories according to areas of protection.................................. 8

Table 2. Main differences between weak and strong sustainability ...................... 20

Table 3. Standards and guides in which the Product Environmental Footprint is based 30

Table 4. Standards and guides in which the Organization Environmental Footprint is based

Table 5. Bibliometric and Scientometric analysis of the Environmental Footprint dataset and Environmental Footprint and Life Cycle Assessment dataset.

Table 6. Characteristics by year of publications of the Environmental Footprint field from 1992 to 2018 45

Table 7. Co-occurrence of keywords in the Environmental Footprint literature. .50

Table 8. Characteristics by year of publications of the Environmental Footprint and Life Cycle Assessment field from 1992 to 2018

Table 9. Co-occurrence of keywords in the Environmental Footprint and Life

Cycle Assessment literature

Table 10. Co-occurrence of journal sources in the Environmental Footprint and

Life Cycle Assessment literature

Table 11. Co-occurrence of countries in the Environmental Footprint and Life Cycle Assessment literature 59

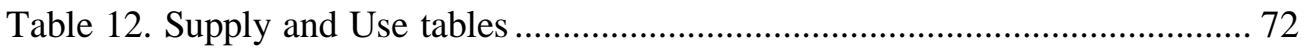

Table 13. Simplified input-output table ……….................................................. 73

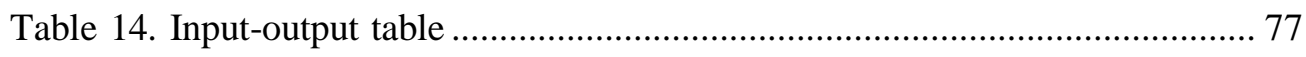

Table 15. Overview of the main MRIO databases................................................ 82

Table 16. Environmentally-extended multi-regional input-output (EEMRIO) framework 83

Table 17. Obtained environmental vectors $R_{i}$ using the characterization factors from ILCD and the corresponding environmental accounts from EXIOBASE2 ............. 85 



\section{INTRODUCTION}





\section{Global Environmental change and sustainable development}

The fact that humans impact the natural world is evident. It is believed that global environmental change is a complex process in which humans are the source and drivers of change (IPCC, 2007a). In order to ensure the planet's survival, an urgent re-connection between humans and nature is needed (Ives et al., 2017). In this way, the concept of sustainable development has gained worldwide attention in recent years (Du Pisani, 2006). However, achieving this target means facing numerous challenges. To overcome them, different initiatives have appeared, such as the Sustainable Development Goals. These ambitious targets involve ecological, social and economic interactions establishing these aspects as the main pillars for sustainability (Goniadis, 2015).

\subsection{Global Environmental change}

Planet Earth has experienced constant transformations over time, from the development of the atmosphere giving rise to life to the disappearing of other species due to drastic climate changes (Ahmed, 2018). As part of living organisms, humans need to interact with nature, which provides goods and natural resources. However, exponential population growth and economic development have caused environmental issues never

experienced before (Meadows et al., 2018). Nowadays, humans are the source of unprecedented environmental changes that need to be faced.

\subsubsection{The Anthropocene Epoch}

Humans have been in existence for only a very small fraction of the Earth's history, in which different geological eras have taken place. Around 11700 years ago, on the 
onset of the Holocene Epoch, the agriculture took root (Fairbridge, 2018). Following this event, limiting factors in the environment, such as food and water availability, shelter, the presence of pathogens, among others, gradually diminished. The development of agriculture propelled population growth, as more people could be supported by the environment, leading to the proliferation of large settlements and the emergence of civilizations (National Geographic, 2018). For those reasons, the Holocene is known as a stable era with a very accommodating global environment for the development of humanity (Live Science, 2013).

However, the Industrial Revolution of the $19^{\text {th }}$ century was the starting point of the environmental deterioration. The industrial era began with a greatly enhanced use of fossil fuels and with it came the great acceleration of the economic activity. Industrialization, improved sanitation and medical care causing death rates to decline, while birth rates continued to climb in most parts of the world (Du Pisani, 2006). Not only population and global economy increased, but also material consumption grew many times faster. Economic growth and technological advances provided numerous benefits in improving humans' well-being. However, world economies continued to expand at the expense of great environmental burdens. Such is the imprint of human activities on global environment that a new epoch known as Anthropocene has been established (Zalasiewicz et al., 2017).

This epoch was popularized by the atmospheric chemist Paul Crutzen and the ecologist Eugene Stoermer (De Gruyter, 2015). What outstands from this era is the environmental shift from the relative stable atmospheric and environmental conditions of the Holocene to the exaggerated resource consumption, habitat transformation and fragmentation, energy production and consumption, and climate change of the Anthropocene (Dalby, 2016). The environmental impacts caused by humanity can be 
estimated by means of three aspects, population, affluence as an indicator for consumption, and technology (Figure 1) (Kolbert, 2011).

In light of these events, the International Geosphere-Biosphere Programme was designed to study contemporary environmental change on a global scale combining the expertise of multiple academic subjects, from climatology to oceanography to biography (European Environmental Agency, 2018). Earth system scientists are suggesting current development is beyond "planetary boundaries". The Planetary Boundaries approach (Rockström et al., 2009) attempts to define conditions for the interaction between humanity Earth's natural system identifying levels relating to critical global-scale processes beyond which humanity should not go. It is believed that the environmental conditions of the Holocene are more favorable than the global changes experienced during the Anthropocene.

The Earth's capacity was represented by nine global environment components constituting the planetary boundaries (Rockström et al., 2009). These components are climate change, ocean acidification, stratospheric ozone depletion, interference with the global phosphorus and nitrogen cycles, rate of biodiversity loss, global freshwater use, land-system change, aerosol loading and chemical pollution (Figure 2). Seven of these nine environmental aspects specify a quantitative boundary, while two of them have not yet been quantified (aerosol loading and chemical pollution). For climate change and ocean acidification the global-scale thresholds are well-established, while for stratospheric ozone depletion the threshold is not clear. These three components are systemic processes at the planetary scale. Other boundaries, such as phosphorus and nitrogen cycles, atmospheric aerosol loading, freshwater use and land use change present associated thresholds. Finally, biodiversity loss and chemical pollution are slower processes than the rest and lack of obvious global-scale thresholds. From this 
categorization it was concluded that climate change and ocean acidification, mainly due to the use of fossil fuels and deforestation, required immediate intervention as they are both planetary processes and are exceeding by far the levels of the Holocene. The rest of the categories included are also recognized as important because of their essential role on supporting life, even though no thresholds have been defined yet. All of the different categories are part of the environment and so, they are connected to each other, meaning that affecting a process could cause severe damage to other processes.

The emerging conditions are characterized by warmer temperatures (Figure 3), with higher sea levels, changed precipitation patterns, impoverished biodiversity and humanmodified landscapes (Bellard et al., 2012; Mimura, 2013). Having the knowledge of how human activities are transforming the environment, care has to be taken to avoid exceeding crucial thresholds which will threaten life in our planet (Steffen et al., 2018).

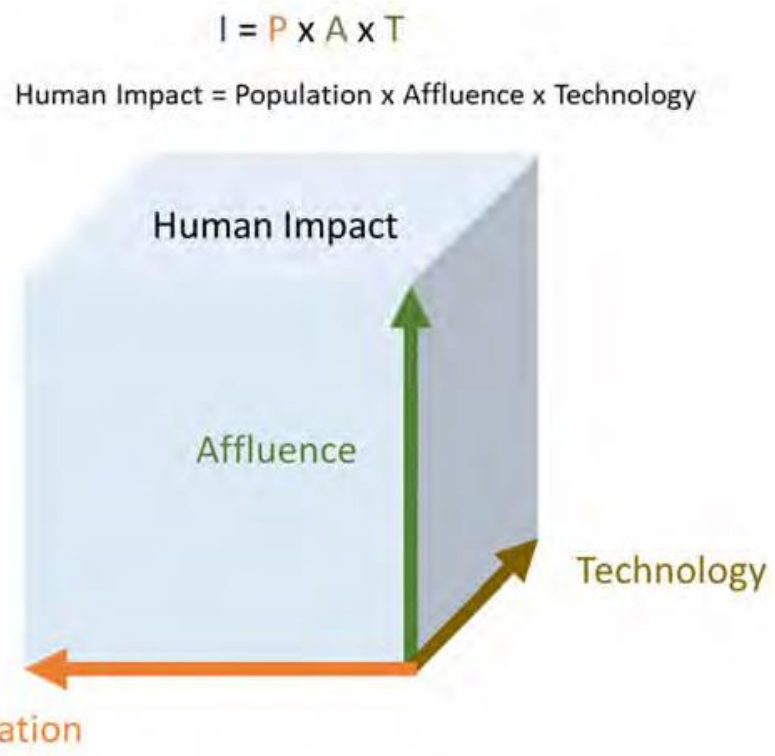

Figure 1. Human impacts estimated by means of three aspects, population, affluence and technology. Adapted from Kolbert (2011). 


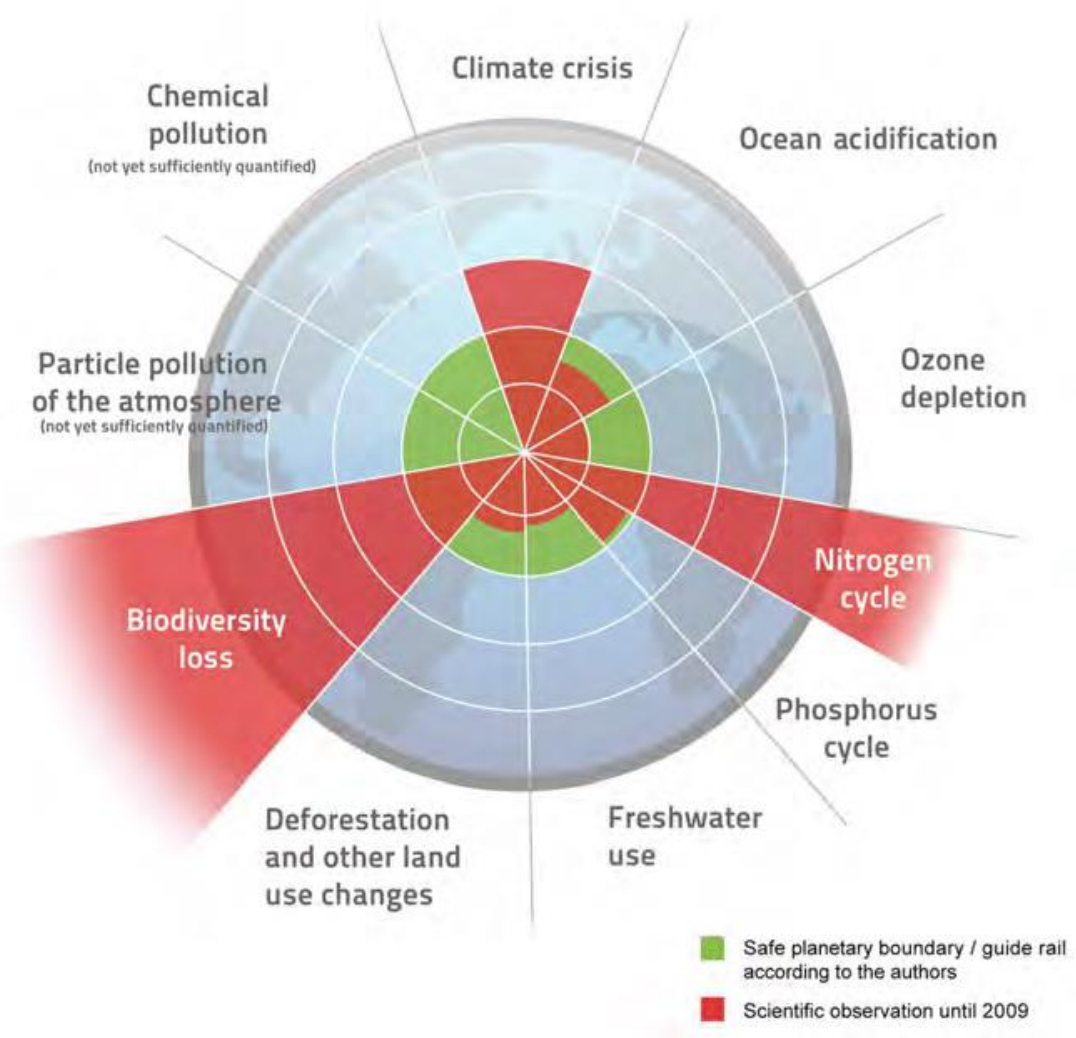

Figure 2. Estimate of quantitative evolution of control variables for seven planetary boundaries from preindustrial levels to 2009 (Rockström et al., 2009).

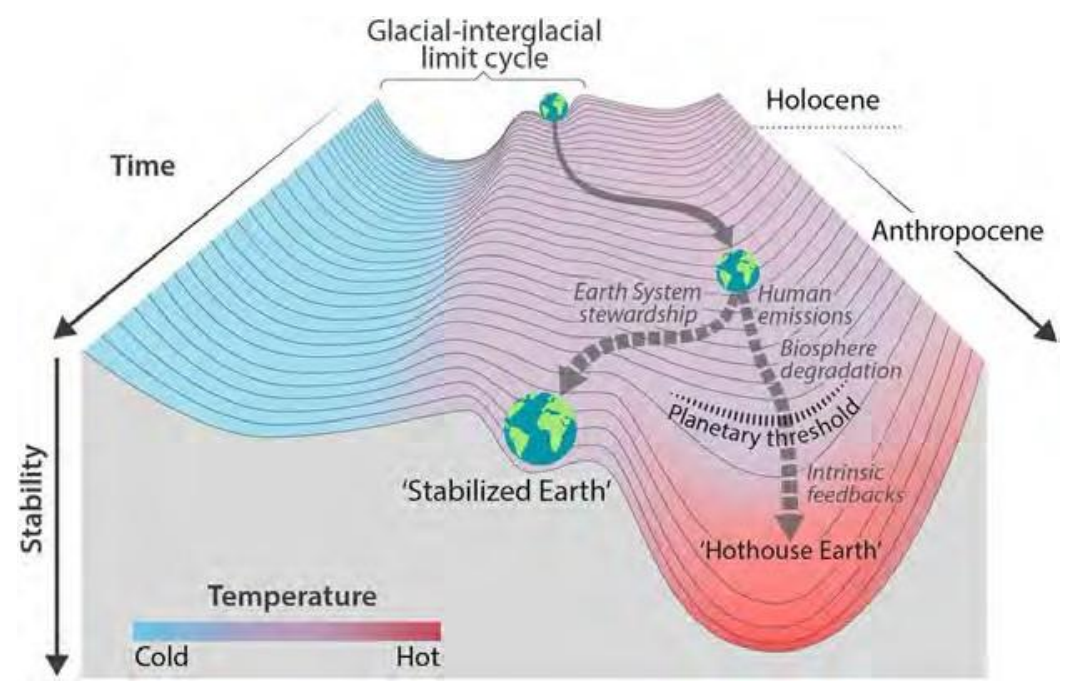

Figure 3. Temperature and stability comparison between the Holocene and the Anthropocene (Steffen et al., 2018). 


\subsubsection{Environmental impacts}

To provide a global perspective of the environmental changes exhibited by human activities three main areas of protection were identified: human health, ecosystem quality, and resources. Fifteen different environmental impact categories were established according to these areas of protection (Table 1) (European commission, 2011).

Table 1. Impact categories according to areas of protection. Adapted from JRC European commission (2011).

\begin{tabular}{|c|c|c|c|}
\hline $\begin{array}{l}\text { Impact Category } \\
\text { scope }\end{array}$ & Area of protection & Spatial & Units \\
\hline Climate change & Human and ecosystem health & Global & $\mathrm{kg} \mathrm{CO} 2 \mathrm{eq}$ \\
\hline Ozone depletion & Human and ecosystem health & Global & $\mathrm{kg} \mathrm{CFC}-11 \mathrm{eq}$ \\
\hline Photochemical oxidation & Human and ecosystem health & Local & $\mathrm{kg}$ NMVOC eq \\
\hline Acidification & Ecosystem health & Local & $\mathrm{kg} \mathrm{SO} 2 \mathrm{eq}$ \\
\hline Eutrophication-terrestrial & Ecosystem health & Local & mol N eq \\
\hline Eutrophication-freshwater & Ecosystem health & Local & $\mathrm{kg} P$ eq \\
\hline Eutrophication-marine & Ecosystem health & Local & $\mathrm{kg} \mathrm{N} \mathrm{eq}$ \\
\hline $\begin{array}{c}\text { Human toxicity (cancer } \\
\text { effects) }\end{array}$ & Health problems & Local & CTUh \\
\hline $\begin{array}{c}\text { Human toxicity (non-cancer } \\
\text { effects) }\end{array}$ & Health problems & Local & CTUh \\
\hline Ecotoxicity freshwater & Ecosystem health & Local & CTUe \\
\hline Land use & $\begin{array}{l}\text { Natural resources and ecosystem } \\
\text { hoolth }\end{array}$ & Global & $\mathrm{kg} \mathrm{C}$-deficit \\
\hline Water depletion & Natural resources & Global & $\mathrm{m}^{3}$-eq \\
\hline Mineral and fossil depletion & Natural resources & Global & $\mathrm{kg} \mathrm{Sb}$-eq \\
\hline Particulate matter & Human health & Local & $\mathrm{kg}$ PM2.5 eq \\
\hline Ionizing radiation & Human health & Local & $\mathrm{kg} \mathrm{U}-235 \mathrm{eq}$ \\
\hline
\end{tabular}

\section{- Climate change}

Also known as global warming or greenhouse effect. This impact category 
addresses the effect of increasing temperature in the lower atmosphere. The radiation from the sun is normally reflected by the surface of the Earth greenhouse gasses, which are present in the atmosphere and reflect or absorb the IR-radiation resulting in an increase of temperature in the lower atmosphere to a level above normal.

The substances contributing to this category are mainly Carbon dioxide $\left(\mathrm{CO}_{2}\right)$, Methane $\left(\mathrm{CH}_{4}\right)$, Nitrous oxides $\left(\mathrm{N}_{2} \mathrm{O}\right)$, CFC's (CFC-11, -12, -113, -114, -115), HCFC's (HCFC-22, -123, -124, -141b, -142b), HFC's (HFC-125, -134a, -152a), Halons, Tetrachloromethane $\left(\mathrm{CCl}_{4}\right)$, 1,1,1-Trichloroethane $\left(\mathrm{CCl}_{3} \mathrm{CH}_{3}\right)$ and Carbon monoxide (CO). The climate change effects are expressed relatively to the effect of $\mathrm{CO} 2$, in $\mathrm{kg} \mathrm{CO}_{2-}$ equivalent.

The possible consequences of the global warming can cause the rise of sea levels due to the melting of the polar ice caps and glaciers. In addition, regional climate changes could also be observed as a consequence of the greenhouse effect (Baxter et al., 2008).

\section{- Ozone depletion}

Ozone molecules $\left(\mathrm{O}_{3}\right)$ in the stratosphere absorb large quantities of the UV radiation from the sun preventing the UV-C radiation and reducing the UV-B radiation from reaching the Earth's surface. Some substances are responsible for the breakdown of ozone, such as chlorine and bromine compounds, methane $\left(\mathrm{CH}_{4}\right)$, nitrous oxide $\left(\mathrm{N}_{2} \mathrm{O}\right)$, and water vapor $\mathrm{H}_{2} \mathrm{O}$. Although they occur naturally in the stratosphere, human activity has enhanced their presence leading to a dangerous reduction in the ozone layer.

The substances included in this category are mainly CFC's (CFC-11, -12, -113, 114, -115), HCFC's (HCFC-22, -123, -124, -141b, -142b), tetrachloromethane (CCl4) and 1,1,1-trichloroethane $\left(\mathrm{CCl}_{3} \mathrm{CH}_{3}\right)$. The ozone depletion category describes the ozone depletion potential from a substance relative to CFC-11, in $\mathrm{kg}$ CFC-11-equivalent. 
Life on the surface of the Earth could be seriously threaten by stratospheric ozone loss. It can cause damage to plants, animals, and humans. In the South Pole, adverse effects have already been seen in the reduction of Phytoplankton, a key agent of the aquatic food chain. In relation to humans, effects in the form of skin cancer and reduced immune defenses could also be consequences of the depletion of the ozone layer (Lizasoain et al., 2015).

\section{- Photochemical oxidation}

Also known as photochemical smog. This impact category relates to the formation of reactive substances, mainly ozone which is formed in the troposphere under the influence of sunlight when nitrogen oxides are present. However, peroxy radicals are highly reactive and toxic compounds, and their presence can result in an increase of the concentration of ozone (Ministry for the Environment New Zealand, 2018).

The principal precursors of tropospheric ozone are NOx, VOC's including $\mathrm{CH}_{4}$ and Carbon monoxide (CO). Photochemical oxidation is expressed in kg NMVOCequivalent.

Tropospheric ozone, or ground level ozone can cause damage to living organisms. At high concentrations it affects human health, but it can also threaten vegetation at low concentrations. Peaks of ozone concentration are known as ozone episodes and it has been reported that anthropogenic emissions have contributed to a rise in the global background of from around $10 \mathrm{ppb}$ in the year 1900 to around $20 \mathrm{ppb}$ in 1975 (Danish Environmental Protection Agency, 2005).

\section{- Acidification}

The release of protons in the terrestrial or aquatic ecosystems are responsible for 
the acidification of the environment. Substances are considered acidifying if the anion is leached out from the system. In certain cases, the alteration of the $\mathrm{pH}$ conditions leads to increased mobility of heavy metals and aluminum.

The substances normally considered as contributors to acidification are sulfur dioxide $\left(\mathrm{SO}_{2}\right)$, sulfur trioxide $\left(\mathrm{SO}_{3}\right)$, nitrogen oxides $\left(\mathrm{NO}_{\mathrm{x}}\right)$, hydrogen chloride $(\mathrm{HCl})$, nitric acid $\left(\mathrm{HNO}_{3}\right)$, sulfuric acid $\left(\mathrm{H}_{2} \mathrm{SO}_{4}\right)$, phosphoric acid $\left(\mathrm{H}_{3} \mathrm{PO}_{4}\right)$ although the anion does not leach and the contribution to acidification is in practice equal to zero, hydrogen fluoride (HF), hydrogen sulfide $\left(\mathrm{H}_{2} \mathrm{~S}\right)$ and ammonia $\left(\mathrm{NH}_{3}\right)$. Acidification potentials are expressed as $\mathrm{SO}_{2}$-eq and $\mathrm{kg} \mathrm{SO}_{2}$-eq.

The impact of acidification can be harmful for terrestrial ecosystems in relation to inefficient growth resulting in vegetation dying. In the aquatic ecosystem the effects are seen in the fact that no wildlife is present. In addition, acid rain damages buildings, constructions, sculptures and other objects (LCANZ, 2018).

\section{- Eutrophication}

Also known as nutrient enrichment. Eutrophication occurs when the enrichment of the environment with nutrients leads to an increased growth of living organisms that causes the depletion of oxygen. Three types of eutrophication have been identified, terrestrial, freshwater and marine.

Eutrophication is caused by phosphorus and nitrogen substances, being this last the decisive factor in marine and terrestrial ecosystems. Different units of measurement are used depending on the type of eutrophication, for terrestrial mol $\mathrm{N}$ eq is used, for freshwater eutrophication $\mathrm{kg} \mathrm{P}$ eq and for marine $\mathrm{kg} \mathrm{N}$ eq is used.

Excessive nutrient enrichment can lead to serious damage in the biological populations inhabiting ecosystems. In addition to this, direct toxic effects on higher 
organisms, including humans must be taken into account when certain species of algae appear in mass (Fox, 2010).

\section{- Human toxicity}

Human toxicity is covered by two impact categories, human toxicity cancer effects and human toxicity non-cancer effects, and includes the toxic effects exhibited by certain substances to human beings.

The substances contributing to human toxicity are numerous. Some of these substances are Heavy metals (cadmium, lead, mercury etc.), Nitrous oxides (NOx), Sulfur dioxide $\left(\mathrm{SO}_{2}\right)$, Volatile organic compounds (VOC), Chlorinated organic compounds, persistent organic pollutants (POP) and particulate matter (PM10). This impact categories are expressed as Comparative Toxic Unit for human (CTUh), expressing the estimated increase in morbidity in the total human population per unit mass of a chemical emitted.

Some of the effects caused by this impact categories are acute toxicity, irritation/corrosive effects, allergenic effects, irreversible damage/organ damage, genotoxicity, carcinogenic effects, toxicity to reproductive system/teratogenic effects, and neurotoxicity (Arora and Schlick, 2004).

\section{- Ecotoxicity freshwater}

Ecotoxicity freshwater is related to the impact on fresh water ecosystems, as a result of emissions of toxic substances to air, water and soil, describing fate, exposure and effects of toxic substances.

This impact category includes substances such as organotin compounds, metals, organic substances/persistent organic pollutants (POP) and pesticides. The units used in this impact category is the Comparative Toxic Unit for ecosystems (CTUe). 
The chemical substances responsible for the ecotoxicity freshwater cause the biodegradability, potential bioaccumulation and lastly, the increase of mortality of living organisms (ECETOC, 2016).

\section{- Land use}

Land occupation and land transformation cause environmental impacts by occupying and transforming the land. In addition, agricultural, forestry, industrial and other processes cause direct emissions to air, water, and soil and cause changes in soil quality and in the use of natural resources. This impact category is expressed as carbon deficit, in kg C-deficit.

The main environmental impacts include changes in biodiversity, resource availability and soil quality. The soil quality impacts include changes in net productivity and in natural carbon, nutrient and water balances of the land area. In addition, the impact on natural carbon stocks has a direct link to the impact category of climate change (Dalgleish et al., 2007).

\section{- Resource depletion}

Two impact categories are included under this reference, water depletion and mineral and fossil depletion. These impact categories are related to the extraction of minerals and fossil fuels due to inputs into the system, as well as the excessive use of water resources leading to their possible depletion. Resource depletion is expressed as abiotic depletion potential, in $\mathrm{kg}$ Sb-equivalent for mineral and fossil depletion, and for water depletion $\mathrm{m}^{3}$-equivalent is used. Extracting water and mineral and fossil resources can cause very significant damages to ecosystems and human health. Overexploitation should be avoided to prevent these resources from disappearing (Sala et al., 2016). 
Input-Output Analysis for the quantification of the Environmental Footprint. Case studies in Spain

- Particulate matter

Particles in the air can exist across a range of different sizes and chemical compositions. From a health perspective, the size of the particles is important as it affects their ability to penetrate into the lungs and cause adverse health effects. Fine particles, less than 10 microns, can penetrate into the lung and alveoli and therefore may be associated with severe health impacts. In light of these threats, this impact category consider these small particles, rather than the larger ones.

Particulate Matter is a complex mixture of extremely small particles. Particle pollution can be made up of a number of components, including acids (such as nitrates and sulfates), organic chemicals, metals, and soil or dust particles. This impact category is measured in particles with a size of $2.5 \mu \mathrm{m}$, in $\mathrm{kg}$ PM2.5-equivalent (European commission, 2013).

High concentrations of PM2.5 can result in a multitude of health problems, especially of the respiratory tract. In addition, the continuous exposure to small particles could reduce life-expectancy and increase the number of deaths (Xing et al., 2016).

\section{- Ionizing radiation}

This impact category refers to the emissions of radionuclides to air and water from energy production. These can be related to the nuclear fuel cycle (mining, processing, use or treatment of the nuclear fuel) or during more conventional energy generation such as the burning of coal. The units of measurement are $\mathrm{kg} \mathrm{U}-235 \mathrm{eq}$.

Human exposure to ionizing radiation causes alterations in the DNA, which in turn can lead to different types of cancer and birth defects. Similar effects must be expected in other living organisms, but damage to ecosystems is not quantified at the moment. Thus, the only area of protection covered is human health (LCA, 2018). 


\subsubsection{Multilateral Environmental Agreements}

Most environmental impacts are characterized by a transboundary and global nature, requiring international co-operation to overcome the environmental challenges. In this context, several international agreements have been proposed to try to mitigate the negative effects of human activity on nature (National Research Council, 1992).

The Montreal Protocol was an international agreement designed to reduce the production and consumption of ozone depleting substances in order to reduce their abundance in the atmosphere, and thereby protect the earth's fragile ozone Layer. It was agreed on 16 September 1987 and entered into force on 1 January 1989. Several amendments to the protocol have taken place since then to update the control of new chemicals and the creation of new financial mechanisms. It has been considered a successful measure as, since its adoption in 1987, it has successfully eliminated over 98 percent of controlled ozone depleting substances, helping reverse the damage to the ozone layer (European Commission, 2009).

Further on, the Kyoto Protocol was developed, linked to the United Nations Framework Convention on Climate Change, to reduce the greenhouse emissions mostly occurring in developed countries (UNFCCC, 2008). The Kyoto Protocol was adopted in Kyoto, Japan, on 11 December 1997 and entered into force on 16 February 2005. Although important world economies, such as United States and China, did not signed the treatment, the Kyoto Protocol is seen as an important first step towards a truly global emission reduction regime and can provided the architecture for the future international agreement of the Paris Agreement.

The Paris Agreement was an initiative to bridge the current policies and climateneutrality before the end of the century (United Nations, 2015). Its overarching goal was to strengthen the global response to the threat of climate change by keeping a global 
temperature rise this century well below 2 degrees Celsius above pre-industrial levels and to pursue efforts to limit the temperature increase even further to 1.5 degrees Celsius. Additionally, the agreement aims to strengthen the ability of countries to deal with the impacts of climate change. It entered into force on 4 November 2016, and it was a great success with 175 countries signing the agreement, including, this time, the two big economies of China and United States. The implementation of nationally determined contributions would put forward their best efforts to achieve the ambitious goals of mitigating climate change impacts through appropriate financial flows, a new technology framework and an enhanced capacity building framework.

In particular, the European Union (EU) has already ratified many international environmental agreements, whether at global level (multilateral agreements negotiated under the auspices of the United Nations), at regional level (in the context of the United Nations Economic Commission for Europe or the Council of Europe), and sub-regional level (for instance for the management of seas or transboundary rivers). These agreements deal with a wide variety of topics, covering most of the impact categories identified (European Commission, 2017a).

Concerning the EU environmental framework, the Environment Action Programmes have been useful guidelines since 1970. The $7^{\text {th }}$ Environmental Action Programme of the EU (2014-2020) "Living well, within the limits of our planet", establishes three key objectives to achieve by 2020 (European Comission, 2013). It identifies the areas where more action is needed to protect and conserve EU's natural capital, to boost a resource-efficient, low-carbon, green economy and reduce threats to human health and wellbeing linked to pollution, chemical substances and the impacts of climate change. Going a step forward, the 2030 Agenda also proposes measures to eradicate poverty and assure the integration of the social, economic and environmental 
dimensions to achieve a sustainable development by 2030 (European Commission, 2015).

\subsection{Sustainable Development}

The balance between economic growth, care for the environment and social wellbeing is the corner stone of a sustainable development (Howarth, 2012). At the social level, sustainability is focused on eradicating poverty, promoting employment, enhancing quality education, basic healthcare and other measures which led to the development of communities and cultures across the globe (United Nations, 2017). At the environmental level, sustainability aims at conserving natural resources ensuring their protection and rational use (United Nations Environment Programme, 2014). The development of alternative sources of power, saving water, promoting innovation and the production and consumption of environmentally-friendly goods are key goals to reduce pollution and establish environmental sustainability. Finally, economic sustainability aims at ensuring the well-being of the economy and improving humans' standards of living, by raising incomes and providing jobs (Bascom, 2016). It requires an equilibrium between economic growth, meeting basic needs, and a development without harming the environment. In order to achieve sustainability, the goals attending these three pillars (social, environmental and economic) need to be viable, equitable and bearable (Circular Ecology, 2018).

\subsubsection{The concept of Sustainable Development}

The concept of sustainability is not new. It was coined years ago and has evolved over time. In 1972, a group of eminent economists and scientists, known as the Club of Rome, draw the attention towards the limited capacity of natural resources to support the 
continuous economic growth. The report titled "The limits to growth", presented in the United Nations Conference on the Human Environment in Stockholm, is considered the starting point of the awareness that it is possible to achieve economic growth and industrialization without environmental damage (United Nations, 2012).

It was with the publication of the Brundtland Report in 1987 that the new paradigm of sustainable development was popularized and became more widely used. Although several definitions regarding the concept of sustainable development have been elaborated over the years, the most often used definition is the one presented in this report. The Brundtland Report defined sustainable as "development that meets the needs of the present without compromising the ability of future generations to meet their own needs" (Brundtland, 1987). To some extent, this definition seemed vague. However, it captured the issues of the economic growth leading to the environmental degradation and the need for such growth to alleviate poverty.

The idea of conserving the resources for future generations is one of the major features that distinguish sustainable development policy from traditional environmental policy. This new concept of sustainability should be characterized by a long-term stability of the economy and environment. In order to do so, the integration and acknowledgement of economic, environmental, and social concerns should be carried out. While the traditional approach considered these three dimensions separately (Figure 4a), the new concept integrates them. The interconnectedness between the three aspects has been considered in a variety of ways, as pillars (Figure 4b), as concentric circles (Figure 4c), or as overlapping circles (Figure 4d), the latter being the approach adopted by the International Union for Conservation of Nature (Lozano, 2008). 
a)

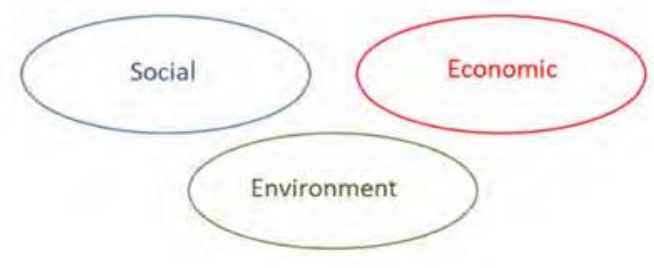

c)

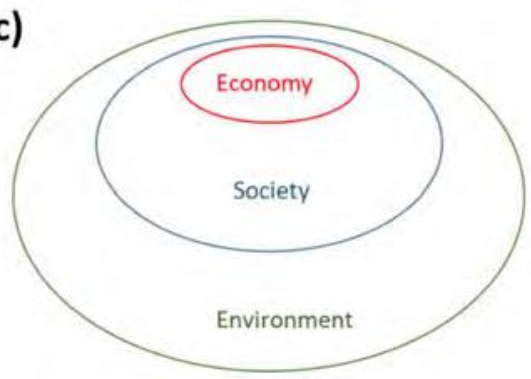

b)

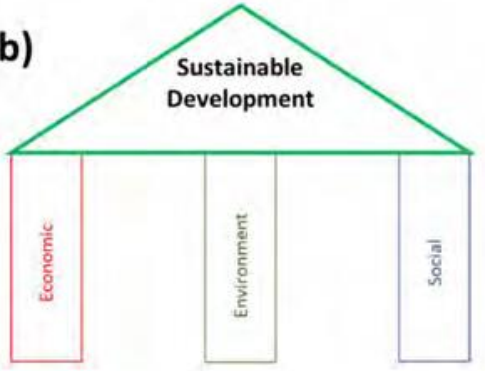

d)

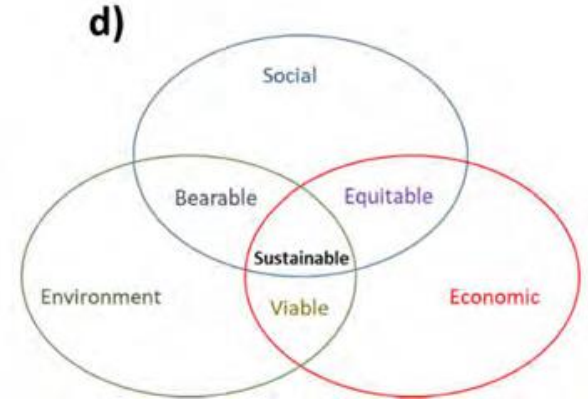

Figure 4. Visual Representations of Sustainable Development: (a) separated, (b) pillars, (c) concentric circles, (d) overlapping circles. Adapted from Lozano, 2008.

Furthermore, the substitutability of the social, natural, and man-made capital determines the type of sustainable development. The definition of weak sustainable development explains that only the aggregate level of capital matters: man-made, or manufactured, capital is an adequate alternative to natural capital. Strong sustainability, on the other hand, recognizes the unique features of natural resources that cannot be replaced by manufactured capital. Most ecologists and environmentalists are proponents of the strong sustainability definition (Table 2) (Pelenc and Ballet, 2015).

The need to eliminate fragmentation is clear. Environmental, social, and economic concerns should be integrated throughout decision making processes. Since the Rio Earth Summit in 1992, the volume and quality of environmental legislation (international, national and local) has expanded hugely, and international agreements, such as the Kyoto protocol, have not only raised the profile of environmental change but also begun to drive global policy change (Adams, 2006). 
Input-Output Analysis for the quantification of the Environmental Footprint. Case studies in Spain

Table 2. Main differences between weak and strong sustainability (Pelenc and Ballet, 2015).

\begin{tabular}{|c|c|c|}
\hline \multicolumn{3}{|c|}{ Main differences between weak and strong sustainability } \\
\hline & Strongsustainability & Weak sustainability \\
\hline Key idea & $\begin{array}{l}\text { The substitutability of natural } \\
\text { capital by other types of } \\
\text { capital is severely limited }\end{array}$ & $\begin{array}{l}\text { Natural capital and other types of } \\
\text { capitals (manufactured etc.) are } \\
\text { perfectly substitutable }\end{array}$ \\
\hline Consequences & $\begin{array}{c}\text { Certain human actions can } \\
\text { entail irreversible } \\
\text { consequences }\end{array}$ & $\begin{array}{l}\text { Technological innovation and } \\
\text { monetary compensation for } \\
\text { environmental degradation }\end{array}$ \\
\hline Sustainability issue & $\begin{array}{c}\text { Conserving the irreplaceable } \ll \\
\text { stocks » of critical natural } \\
\text { capital for the sake of future } \\
\text { generation }\end{array}$ & $\begin{array}{l}\text { The total value of the aggregate stock } \\
\text { of capital should be at least } \\
\text { maintained or ideally increased for } \\
\text { future generation }\end{array}$ \\
\hline Key concept & Critical natural capital & $\begin{array}{c}\text { Optimal allocation of scarce } \\
\text { resources }\end{array}$ \\
\hline $\begin{array}{c}\text { Definition of } \\
\text { thresholds and } \\
\text { environmental norms }\end{array}$ & $\begin{array}{l}\text { Scientific knowledge as input } \\
\text { for public deliberation } \\
\text { (procedural rationality) }\end{array}$ & $\begin{array}{l}\text { Technic/scientific approach for } \\
\text { determining thresholds and norms } \\
\text { (instrumental rationality) }\end{array}$ \\
\hline
\end{tabular}

\subsubsection{Sustainable Development Goals}

At the Millennium Summit in September 2000, building upon a decade of major United Nations conferences and summits, world leaders gathered in New York and adopted the United Nations Millennium Declaration. World countries committing to this declaration aimed at fighting poverty in its many dimensions, from halving extreme poverty to halting the spread of HIV/AIDS and providing universal primary education, with the target date of 2015. These unprecedented efforts were translated into eight targets known as the Millennium Development Goals (MDGs) (United Nations, 2018).

The first MDG addressed poverty directly, while the next six focus on the underlying causes of poverty, such as lack of access to education, health care, and employment, gender 
inequality, poor housing conditions, and environmental degradation. The eighth MDG focused on establishing a global partnership for development in order to enhance the stand of living of the poorer countries. For each MDG a series of indicators were also established to monitor the progress achieved ( UNDP, 2018).

Having reached the target date of 2015 , in September of that year, the international community adopted the Sustainable Development Goals (SDGs). These 17 goals build on the MDGs set in 2000 and are part of a wider 2030 Agenda (United Nations, 2010). They reaffirmed the international commitment to end poverty, protect the planet and ensure life quality and prosperity (Axon and James, 2018).

The SDGs considers the three dimensions of sustainable development, the economic, social and environmental. An important feature is that these targets are indivisible, in a sense that they must be implemented as a whole, in an integrated rather than a fragmented manner, recognizing that the different goals and targets are closely interlinked (Figure 5) (Blanc, 2015). A country's performance on the SDGs is represented by the SDG Index. However, some researchers have declared the limited picture of this indicator (Diaz-Sarachaga et al., 2018). In this sense, as economic growth and society's well-being ultimately depend on ecological assets and the planet's resource capacity, the Ecological Footprint was proposed to measure a specific ecological budget (Global Footprint Network, 2003). Adding the combination of the Ecological Footprint with the UN Human Development Index (HDI) would provide a better understanding of human development (measured by HDI) within a resource demand that fits on this planet (measured by an Ecological Footprint per person) and has to be smaller than the world average biocapacity. It has to be noted that since the appearance of the Ecological Footprint, several footprints also emerged as a way of evaluating the environmental performance of human activities (Fang, 2015). 
Input-Output Analysis for the quantification of the Environmental Footprint. Case studies in Spain

Although SDGs are seen as a necessary initiative towards a sustainable future, constructive criticisms have been stated proposing that the SDGs need to increase their focus on resource security and environmental resilience in order to deliver lasting results (Global Footprint Network, 2017). In line with these criticisms, the report "Projecting Progress Reaching the SDGs by 2030" establishes specific targets for each of the 17 SDGs. It is seen that for some of the goals (marked in red), changes in the current policies are needed, as current ones are not succeeding (Nicolai et al., 2015). Unfortunately, the three goals which appear to be failing in the measures adopted are related to the environment. Therefore, there is a need to face these environmental issues from an integrated perspective, and not just considering climate change.

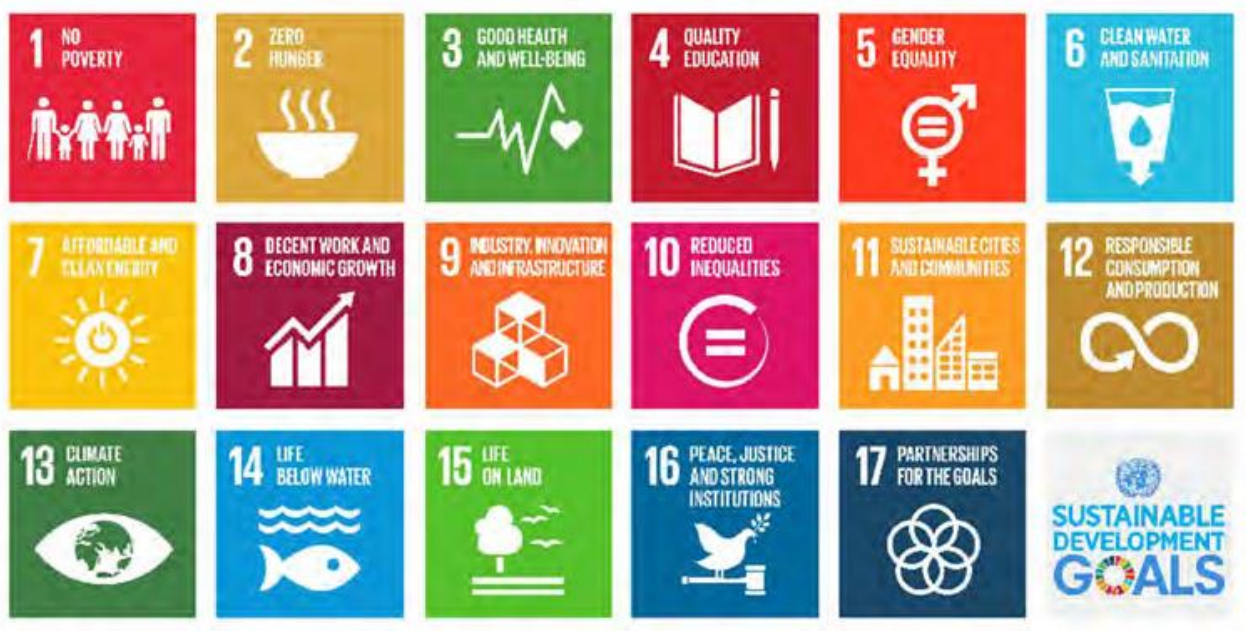

Figure 5. Sustainable Development Goals adopted by the United Nations. 


\section{SDG SCORECARD 2030

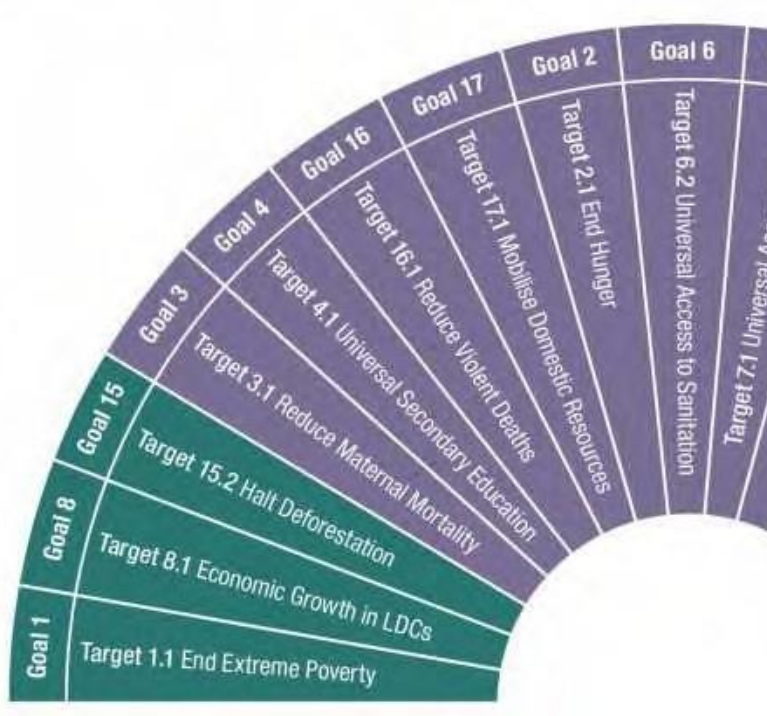

REVERSAL

Figure 6. Scorecard of the selected target per goal (Nicolai et al., 2015).

\subsubsection{Footprint family}

Footprint indicators were developed with the target of providing valuable information to assess human impacts imposed to the environment. Throughout these years, several footprints have been introduced enabling the tracking of natural resources consumption and the impact this use generates, as well as, quantifying the outcomes of specific policies undertaken to reduce the negative environmental impacts of natural resource use (Chen et al., 2017; Ottelin et al., 2018).

The concept of footprint has gained tremendous popularity in the suitability field. It was introduced for the first time in 1990 with the Ecological Footprint. This indicator addressed the topic of planetary boundaries and the management of the planet's ecological assets (Wackernagel et al., 1999). Since then, a suite of indicators analogous to the Ecological Footprint has been developed, which could serve as the basis for approaching 
Input-Output Analysis for the quantification of the Environmental Footprint. Case studies in Spain

an integrated family of footprint indicators (Fang, 2015). Some footprint indicators are the Ecological Footprint (Wackernagel and Rees, 1996), the Carbon Footprint (Wiedmann and Minx, 2007), the Water Footprint (Hoekstra and Hung, 2002), the Energy Footprint (Lan et al., 2016), the Exergy Footprint (Eisenmenger et al., 2016), the Emergy Footprint (Wright and Østergård, 2016), the Chemical Footprint (Sörme et al., 2016), the Nitrogen Footprint (Oita et al., 2016), the Biodiversity Footprint (Moran et al., 2016) and the Phosphorus Footprint (Gronman et al., 2016). These indicators enable the measurement of the impacts of human activities in terms of resource consumption and waste emissions on the environment.

Nowadays, footprint indicators have provided analysts and decision makers with a robust and ready-to-use suite of indicators enabling them to take the first step towards sustainability assessment (Castellani and Sala, 2012; Water footprint Network, 2018). Continuous research in this direction is still being carried out from different perspectives, mainly by chemists, engineers, economists and biologists.

A brief description is provided hereafter for the main footprint indicators: Ecological Footprint, Carbon Footprint, Water Footprint, Energy Footprint, and the Environmental Footprint.

The Ecological Footprint was conceived by Mathis Wackernagel and William Rees (Global Footprint Network, 2003). This indicator measures the ecological assets that a given population requires to produce the natural resources it consumes, including plantbased food and fiber products, livestock and fish products, timber and other forest products, space for urban infrastructure, and to absorb its waste, especially carbon emissions. In other words, it answers the question of how much of the biological capacity of the planet is required by a given human activity or population. It tracks the use of six categories of productive surface areas, such as cropland, grazing land, fishing grounds, 
built-up land, forest area, and carbon demand on land, and excludes deserts, glaciers and the open ocean. In order to enable comparison the measurement unit used is global hectares. Calculation methods include equivalence and yield factors to convert worldaverage hectares into global hectares. The equivalence factors convert one hectare of world-average land of a specific land type into an equivalent number of global hectares. The yield factors convert one hectare of a specific land type within a given nation into an equivalent number of world-average hectares of that same land type. The standardization and complete methodology is managed through the organization Global Footprint Network, with Mathis Wackernagel at its forefront. Several advantages, such as transmitting an unambiguous message and the low level of difficulty in its calculation, have been recognized for the implementation of this indicator. However, limitations have also been highlighted, such as ignoring technological change, underground resources and flows, as well as, not considering the aspect of equity in its measures (Moffatt, 2000).

Among the several definitions of Carbon Footprint, the most common is the established by Wiedmann and Minx in 2008 (Wiedmann and Minx, 2008). They proposed the following definition: "The carbon footprint is a measure of the exclusive total amount of carbon dioxide emissions that is directly and indirectly caused by an activity or is accumulated over the life stages of a product". The standardization of this footprint was initiated by the British Standards Institution, known as PAS 2050 and focused on the product Carbon Footprint (British Standard Institute, 2011). The Global Footprint Network includes the Carbon Footprint as part of the Ecological Footprint, interpreted as the demand on " $\mathrm{CO}_{2}$ area" or " $\mathrm{CO}_{2}$ land". However, the expression of Carbon Footprint in land area carries uncertainties and errors. Therefore, mass units of carbon dioxideequivalent ( $\mathrm{kg} \mathrm{CO}_{2}$-eq), which are similar as the global warming potential indicator used in life cycle assessment (LCA), are used (Wiedmann and Minx, 2008). In order to calculate 
Input-Output Analysis for the quantification of the Environmental Footprint. Case studies in Spain

this indicator several calculators have been developed and are available making use of the different emission factors (Carbon Footprint, 2018). Organizations around the world, such as carbon Trust, are promoting the calculation of the Carbon Footprint and contributing to reduce carbon emissions (Carbon Trust, 2018).

The concept of Water Footprint was presented by Arjen Hoekstra in 2002 and it was meant to be a measure of humanity's appropriation of fresh water in volumes of water consumed and/or polluted (Hoekstra, 2002). There are three types of Water Footprint, the Green, the Blue and the Grey Water Footprint. The Green Water Footprint refers to the water from precipitation that is stored in the root zone of the soil and evaporated, transpired or incorporated by plants. The Blue Water Footprint is water that has been sourced from surface or groundwater resources and is either evaporated, incorporated into a product or taken from one body of water and returned to another, or returned at a different time. Finally, the Grey Water Footprint is the amount of fresh water required to assimilate pollutants to meet specific water quality standards. The Water Footprint has been applied in several fields, such as national studies (Ercin et al., 2013), catchment studies (Zeng et al., 2012), global assessments (Hoekstra and Mekonnen, 2012), sector studies (Mekonnen, 2015), product assessments (Chapagain et al., 2005) and diet assessments (Vanham et al., 2013). In order to promote sustainable water use, professor Hoekstra together with multilateral organisations, civil society, academia and business founded the Water Footprint Network. This international organization was created with the aim of providing a scientific approach and strategic insights for companies, governments and individuals that would shift the fresh water use to quantities within earth's limits (Water footprint Network, 2018).

The Energy Footprint is a component of the Ecological Footprint and it was defined as the areas required for sequestering the amount of $\mathrm{CO}_{2}$ emissions from burning fossil 
fuels, for buffering the radiation from nuclear power, and for building dams to generate hydrological electricity (Mathis Wackernagel et al., 1999b, 1999a). However, criticism has arisen concerning this indicator due to the high variability of the results obtained from the Energy Footprint when alternative energy policies are carried out (Bergh and Verbruggen, 1999). Additionally, in most cases, this indicator has a very significant contribution to the overall Ecological Footprint. For that reason, Jiun-Jiun Ferng in 2002 carried out a specific analysis of the Energy Footprint (Ferng, 2002). The aim of the study was to calculate this indicator independently from the Ecological Footprint considering the direct and indirect final demands causing an Energy Footprint. It was also emphasized the importance of this measurement as a tool for implementing energy policies. Several sub-footprints can be identified within the wider Energy Footprint, such as nuclear energy footprint, renewable energy footprint, solar energy footprint and fossil energy footprint (Cucek and Kravanja, 2012).

\section{Environmental Footprint}

Over the past years, there has been a significant proliferation of indicators, including footprints, for measuring the environmental performance of human activities. However, the calculation methods adopted for each indicator can vary, leaving the results as misleading and incomparable. In order to solve these discrepancies, the European Commission decided to establish the Environmental Footprint (EF) as a multi-criteria measure calculated following a specific methodology (Sonnemann et al., 2015).

\subsection{Context and types of Environmental Footprint}

The European Commission's Roadmap to a Resource Efficient Europe by 2020 was 
Input-Output Analysis for the quantification of the Environmental Footprint. Case studies in Spain

an initiative aiming at increasing resource productivity and economic growth without depleting the planet's resources and reducing the environmental impacts, from a life cycle perspective (European Commision, 2014). In addition, Europe wanted to achieve an alignment between the Member States and establish a Single Market for Green Products (European Commission, 2017b). Following this path, the main objective of creating a new indicator was to establish a common methodological approach to enable Member States and the private sector to assess, display and benchmark the environmental performance of products, services and companies based on a comprehensive assessment of environmental impacts over the life cycle (European Commission, 2017c).

By adopting a life cycle perspective the impacts along the entire supply chain of a product and an organization could be considered and it also enabled the identification of the hotpots which contribute the most to the environmental impacts (Sonnemann et al., 2015). Contrary to other indicators which focus only on a single environmental impact, such as the Carbon Footprint, the EF is a multi-criteria approach. Fifteen impact categories can be assessed by means of this indicator, being climate change; ozone depletion; human toxicity-cancer effects; human toxicity-non-cancer effects; particulate matter; ionising radiation; photochemical ozone formation; acidification; eutrophication terrestrial; eutrophication marine; eutrophication freshwater; ecotoxicity freshwater; land use; resource depletion-water; resource depletion-mineral and fossil fuel (European Commission, 2013, 2012).

There are two types of EFs, the Product Environmental Footprint (PEF) and the Organization Environmental Footprint (OEF). The PEF is a multi-criteria measure of the environmental performance of a good or service throughout its life cycle. The purpose of this indicator is to reduce the environmental impacts of goods and services (European Commission, 2012). On the other hand, the OEF is a multi-criteria measure of the 
environmental performance of a goods/services provided by companies, public administrative entities, territories, and other bodies from a life cycle perspective. The target of this indicator is to reduce the environmental impacts associated with organisational activities, taking into account supply chain activities (European Commission, 2013). Both PEF and OEF are complementary indicators, each undertaken depending on the objective of the assessment. Additionally, depending on the intended application, when setting the boundaries of the study, it can be gate-to-gate, cradle-to-gate, or cradle-to-grave assessments.

These two approaches are based on well-recognized standards and guides (Table 3 and Table 4) (EC Institute for Environmental and Sustainability, 2010). Also, a key target for this indicator was achieving results that could be compared and that the studies carried out using this footprint would show consistency. In that way, the Product Environmental Footprint Category Rules (PEFCRs) and the Organisation Environmental Footprint Sector Rules (OEFSRs) were created to provide technical guidance on how to conduct a product and organization environmental footprint study. During a period of three years, 2013 to 2016, a pilot phase took place to develop the PEFCRs and OEFSRs based on the results of 26 pilots (Kerkhof et al., 2017). The pilot phase has provided some valuable insights on the development of the Environmental Footprint as an indicator to communicate in a clear and transparent way, the environmental performance of products and organizations (Bach et al., 2018). 
Input-Output Analysis for the quantification of the Environmental Footprint. Case studies in Spain

Table 3. Standards and guides in which the Product Environmental Footprint is based.

\begin{tabular}{ll} 
Standard / Entity & Methodology guides \\
\hline ISO 14044 & Life cycle assessment - Requirements and guidelines \\
ISO 14067 & Carbon footprint of products \\
ILCD & International Reference Life Cycle Data System \\
GFN & Ecological Footprint \\
WRI/ WBCSD & Product and supply chain standards, Greenhouse Gas Protocol \\
BPX 30-323 & $\begin{array}{l}\text { Méthodologie d'affichage environnemental (BPX 30-323) } \\
\text { PAS 2050 }\end{array}$ \\
\hline
\end{tabular}

Table 4. Standards and guides in which the Organization Environmental Footprint is based.

\begin{tabular}{ll} 
Standard / Entity & Methodology guides \\
\hline ISO 14064 & Greenhouse gases -Part 1, 2 and 3 \\
ISO/WD TR 14069: & \\
GHG & Quantification and reporting of GHG emissions for organisations \\
ILCD & International Reference Life Cycle Data System \\
WRI/ WBCSD & $\begin{array}{l}\text { Corporate Accounting and Reporting Standards, Greenhouse Gas } \\
\text { Protocol }\end{array}$ \\
ADEME & Bilan Carbon \\
DEFRA & Carbon Disclosure Project (CDP) \\
DEFRA & CDP Water \\
PNUMA & Global Reporting Initiative (GRI) \\
\hline
\end{tabular}

\subsection{Environmental Footprint and Life Cycle Assessment}

The EF is based on Life Cycle Assessment (LCA). This approach includes both direct impacts (i.e. impacts on the production site, impacts of transport vehicles) and indirect impacts (i.e. occurring in the supply chain, at extraction, occurring in the use stage) (Figure 7) (Vieira, 2018a). 


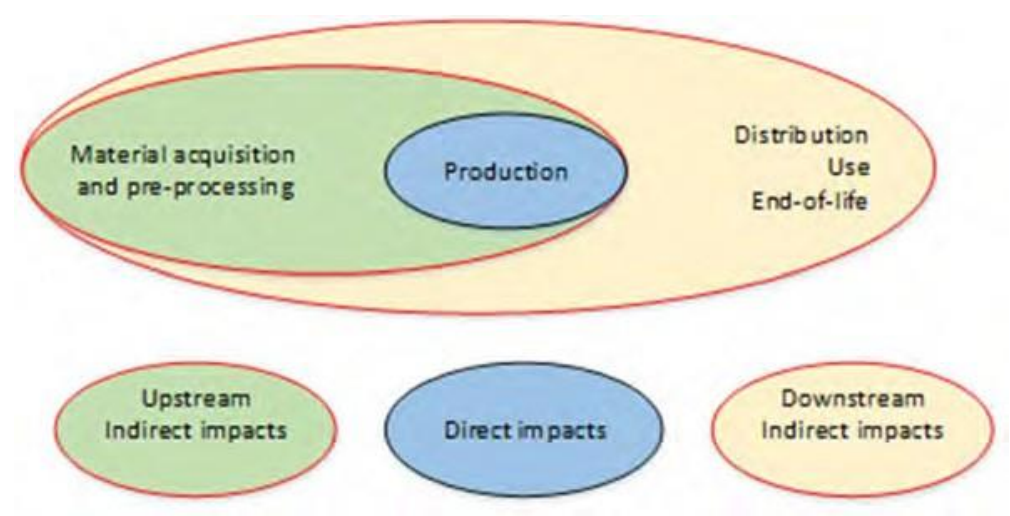

Figure 7. Environmental Footprint boundaries and impacts.

\subsubsection{History of Life Cycle Assessment}

According to Guinee et al. (2011), different periods can be identified in the history of LCA. In the first period, from 1970 to 2000, the LCA was conceived. In particular, it was in 1969, when the foundation of the LCA was initiated by an internal study was conducted by Midwest Research Institute for the Coca Cola Company. This study aimed to compare different beverage containers to determine which had the lowest environmental impacts. Since then, several studies followed this investigation during the following years. In the United States, the Midwest Research Institute adopted the term Resource and Environmental Profile Analysis for the process of quantifying the resource use and environmental releases of products, while in Europe it was known as Ecobalance.

During the 1970s and the 1980s the proliferation of LCA studies were evident. However, the lack of harmonization and standardization led to a great variety using different methods to carry out the investigations. For that reason, between 1990 and 2000, LCA guides and handbooks were produced. The LCA framework was enhanced by the Society of Environmental Toxicology and Chemistry, which motivated LCA practitioners, users and scientists on the continuous improvement and harmonization of LCA (SETAC, 
Input-Output Analysis for the quantification of the Environmental Footprint. Case studies in Spain

2018). Further on, in 1994, the International Organization for Standardization (ISO) developed two international standards: "Environmental management - Life cycle assessment - Principles and framework" (ISO 14040, 2006) and "Environmental management - Life cycle assessment - Requirements and guidelines" (ISO 14044, 2006).

From 2002, with the Life Cycle Initiative, which was an International Life Cycle Partnership between the United Nations Environment Programme and the Society of Environmental Toxicology and Chemistry, three programs were developed. The Life Cycle Management program focused on improving the skills and establishing training programs and forums related to LCA (Life Cycle Initiative, 2007a). On the other hand, the Life Cycle Inventory (LCI) programme was dedicated to improving the accessibility to transparent, high quality life cycle data (Life Cycle Initiative, 2007b). Finally, the Life

Cycle Impact Assessment programme, aimed at promoting the results obtained and recommendations (Life Cycle Initiative, 2007c).

\subsubsection{Life Cycle Assessment description}

As previously mentioned, the EF relies on the quantification of all the environmental impacts along the supply chain of a product or service, from raw material acquisition through processing, distribution, use, and end-of-life processes, and all relevant related environmental impacts.

In order to carry out a study of the PEF or the OEF, there are five phases (Figure 8) (European Commission, 2013, 2012). Initially, the goal of the EF study has to be defined. The intended application, the reasons for conducting this study, the target audience and the limitations should be included. Next is the Scope's definition, where the unit of analysis, system boundaries and impact categories are established. Cradle-to-grave approach is the appropriate way of establishing the boundaries, and deviations from it 
should be justified (Figure 9). The following phase is the documentation of the resource use and emissions profile, which is compiling an inventory, known as profile, of all material and energy resource inputs and outputs and emissions into air, water and soil. The meaning is quite similar to the term "life cycle inventory" used in ISO 14044 (European Commission, 2013, 2012).

The EF impact assessment is carried out to calculate the environmental performance of a product or organization, using the Resource Use and Emissions Profile and the selected impact categories and models. The mandatory sub-phases of this assessment are the classification, which means the allocation of the inputs and outputs to the impact categories to which they contribute, and characterisation, which is the magnitude of the contribution of each input and output within the impact categories. On the other hand, the optional phases are the normalization and weighting. The normalization is carried out to compare the magnitude of the inputs and outputs contributions to the impact categories relative to a reference unit, and the weighting reflects the relative importance of the impact categories considered (Vieira, 2018b).

In the final phase of the study, the interpretation sets two purposes. The first is to ensure that the performance of the PEF and OEF models correspond to the goals and quality requirements of the study. The second purpose is to derive robust conclusions and recommendations from the analysis, for example in support of environmental improvements. Additionally, reporting enables the communication of the results in a clear and transparent way and allows future users to carry out environmental studies following this procedure (European Commission, 2012). 
Input-Output Analysis for the quantification of the Environmental Footprint. Case studies in Spain

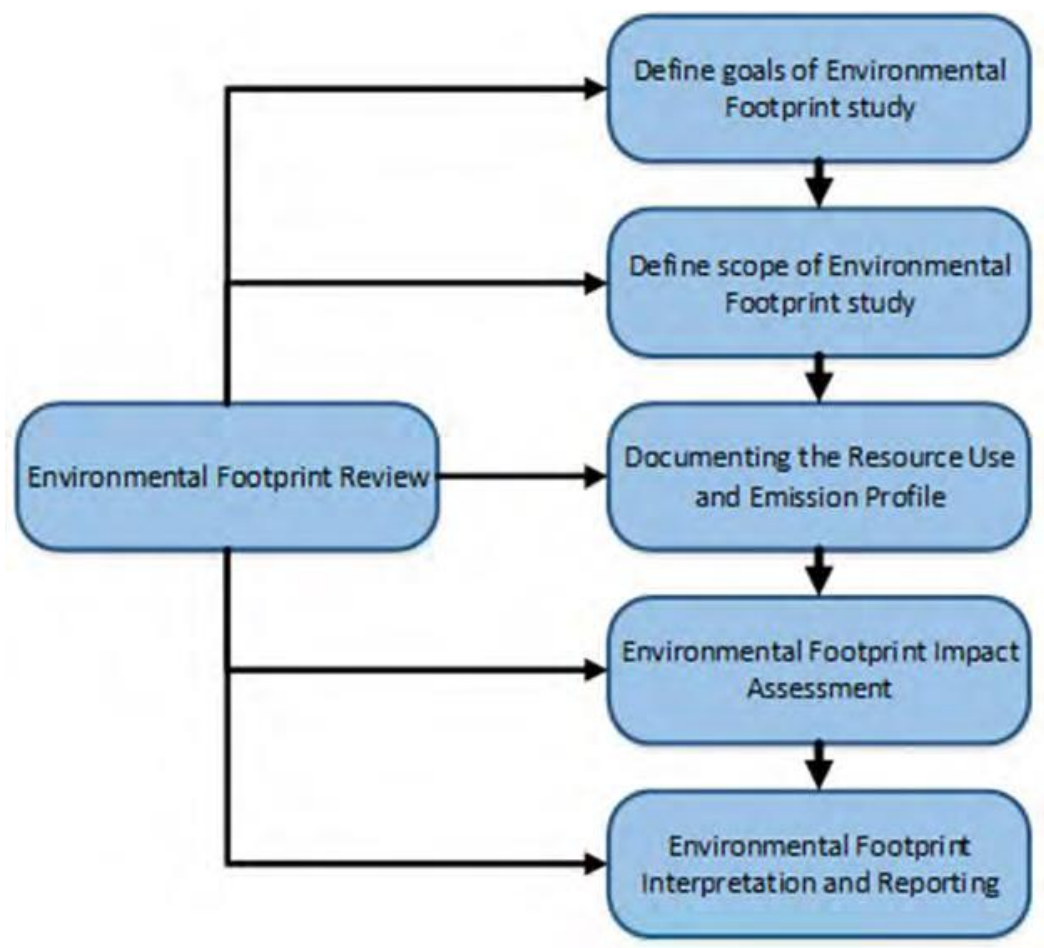

Figure 8. Process overview for Environmental Footprint Studies.

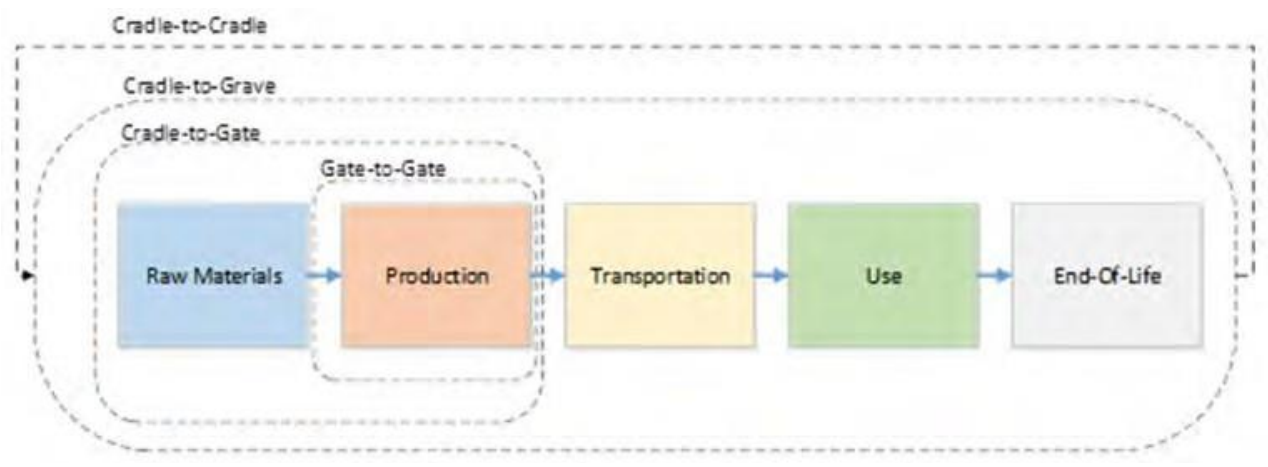

Figure 9. Environmental Footprint approaches regarding system boundaries.

\subsubsection{Life Cycle Assessment's methods}

When carrying out the EF impact assessment, it is often ignored the existence of different methods to conceptualize and measure environmental impacts. There are three main methods (Process-based LCA, Input-Output LCA and Hybrid LCA) and their use could exhibit different results. Therefore, choosing the most suitable method depends on 
the specific goal of the LCA study. Knowing the advantages and limitations of each available LCA method facilitates the selection of the method according to the scope of the study, as well as, the resources and time available.

\subsubsection{Process-based LCA}

- Method description

This method is a "bottom-up" approach, which has been the most popular method for conducting LCA (Suh and Huppes, 2005). The process-based method relies on process flow diagrams that show how processes of a product or service system are interconnected through commodity flows. Inputs, which are the materials and energy resources, and the outputs, which are the emissions and wastes to the environment, are known as a processes (Figure 10). Different processes have to be considered throughout the entire lifespan of a product or service and the number of them depend on the boundaries set for the study. The processes included in the study conform the system (Figure 11).

With even moderately large systems, data handling and calculation can be complex and so, multiple LCA software and databases have been developed to assist researchers. The target of using these tools are to reduce time needed for assessments, to prevent errors, to increase capabilities, for example monte carlo simulations and sensitivity analyses, to organize systems and data, to automate creation of graphs and tables, etc. However, some software and databases can be fairly expensive and require a learning curve to use effectively. The most popular tools available in the market are SimaPro, paid software produced by Pré Consultants, GaBi, paid software produced by Pe International, Umberto, paid software produced by Ifu Hamburg, Quantis Suite, which is a web-based application used for calculating the environmental performance of companies, and OpenLCA, paid software developed by GreenDelta. 
Input-Output Analysis for the quantification of the Environmental Footprint. Case studies in Spain

INPUTS

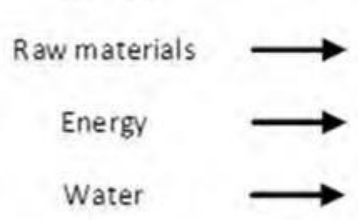

Process

Water

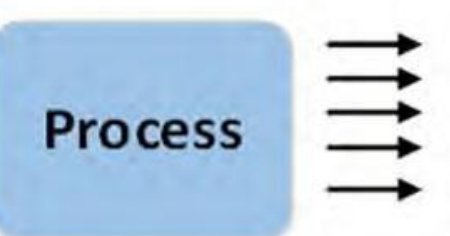

Emissions to air

Releases to water

Solid waste

Usable products

Other environment al

releases

Figure 10. Process description.

INPUTS

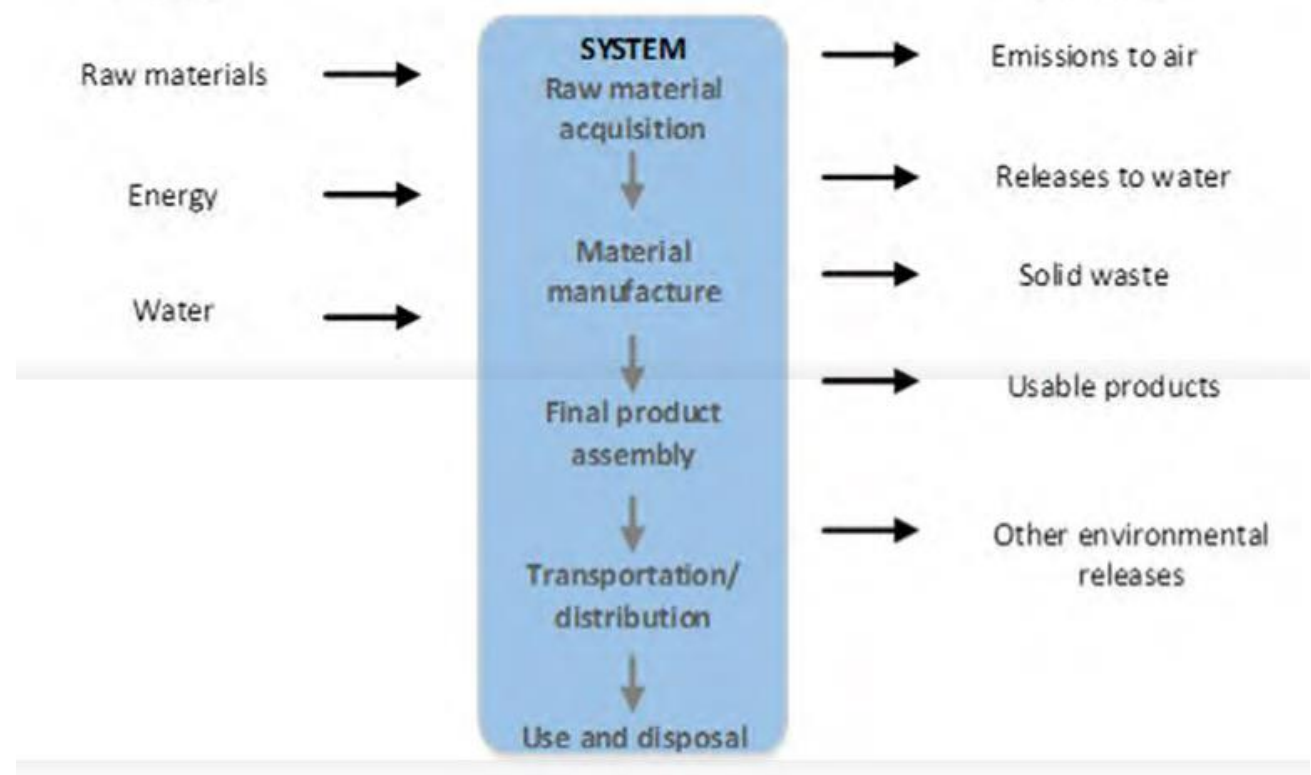

Figure 11. System description.

- Advantages and disadvantages

The process-based method is the most common form of carrying out a LCA because it presents high accuracy in its results. Additionally, this approach is preferred to assess the environmental performance of case-specific products or systems.

On the other hand, a series of limitations arise with the process-based method. It has been recognized as a time-consuming and expensive approach, requiring the exhaustive collection of empirical data or secondary data from other sources (Suh and Huppes, 2005). In order to overcome this limitation, capital goods and upstream processes 
are cut off to create a manageable LCA project and therefore, reduce the time and effort needed to collect information on the inputs and outputs. However, this results in truncation errors and underestimation of the true life cycle impacts (Lenzen, 2001). In fact, the underestimation of carbon emissions with this method has been reported to be $30 \%$ of the total emissions (Majeau-Bettez et al., 2011). Another main issue is the circularity effect. Calculation can be complicated when the system involves multifunctionality or interconnecting inputs between processes (Ling-Chin et al., 2016).

\subsubsection{Input-Output LCA}

\section{- Method description}

The input-output (IO) method is a "top-down" approach based on monetary transactions between industry sectors in mathematical form. This approach indicates what goods or services (or output of an industry) are consumed by other industries (or used as input). Economic input-output models are presented in matrix form. The monetary transactions among industry sectors are published in input-output tables (IOT), which are national data on the supply and consumption of goods and services. In these tables, each row and each column represent a single industry sector, and the intersection of a row and column identifies the economic value of output from the row sector that is used as input to the column sector. In this sense, it can be identified if the output of an industry sector is required as input to the same industry sector, which in this case the value along the diagonal of the matrix will be non-zero. Furthermore, using some basic linear algebra techniques, direct, the indirect, and total effects of changes to the economy can be spotted. Direct effects are the first-tier transactions, the transactions between one sector and the sectors that provide it output. Indirect effects are the second-tier, third-tier, etc. transactions, these are the transactions among all sectors as a result of the first-tier 
transactions. Total effects are the sum of direct and indirect effects (see material and methodology section).

The IO method is also capable of studying changes in the demands or structure of the economy. Economic input-output models allow the estimation of the effects of economic changes when final demands varies. This serves as a tool for decision-makers to estimate the results of implementing different measures.

\section{- Advantages and disadvantages}

Compared to the process-based method, the IO approach usually presents smaller data requirements and the time and labor intensity are reduced. Regarding the system boundaries, the IO method shows high completeness, as it includes the upstream and downstream effects. This way it avoids the limitation of the truncation effect. Finally, the IOT are usually publicly available, not incurring in time and additional costs to carry out the study compared to expensive software and databases used for the process-based method (Kjaer et al., 2015).

However, this method has also some inherit limitations. When using the IOT it is assumed that technological coefficients are fixed and that sector and product types are homogeneous. Thus, homogeneity and linearity limitations have to be acknowledged (Nässén et al., 2007). Another shortcoming is the sectorial aggregation (Majeau-Bettez et al., 2011). Finally, the temporal difference between the IOT and inventory data is also regarded as a constraint. Most IOT are not compiled in a timely fashion, requiring some adjustments to be made to the calculated values. For instance, the translation of prices using inflation factors, such as the Consumer Price Index. 


\subsubsection{Hybrid LCA}

\section{- Method description}

For a comprehensive analysis, the combination of the process-based and IO methods has been studied. While process-based can provide a detailed analysis of specific process flows, IO is able capture the interrelations between all sectors of the economy. Thus, the hybrid approach combines the strengths of both methods.

There are different types of hybridization, the tiered hybrid approach, the IO based hybrid approach and the integrated hybrid analysis (Ling-Chin et al., 2016). Tiered hybrid analysis utilizes process-based analysis for the use and disposal phase, as well as, for several important upstream processes, and then the remaining input requirements are imported from an IO-based LCI. This is, direct inputs to main processes are calculated with detailed process analysis while upstream flows that are indirectly connected to the main processes are estimated via IO based approach (Ling-Chin et al., 2016). Tiered hybrid analysis can be performed simply by adding IO-based LCIs to the process-based LCI results (Suh and Huppes, 2005). The IO-based hybrid approach, also known as hybrid LCI method based on IO data, consists of disaggregating industry sectors in the IO table to improve process specificity. Then, for the use and end-of-life stages of the product life cycle, the tiered hybrid method is applied. Finally, in the integrated hybrid analysis detailed information at unit process level is fully incorporated into IO model by linking process-based system, represented in a technology matrix by physical units, and the IO system, in monetary units, through flows crossing the border of both systems. In this last approach the use and disposal phases can be expressed by the LCA technology matrix, so there is no need to apply a tiered hybrid method to complete an LCI, and thus full interactions between individual processes and industries can be modelled in a consistent framework. 
- Advantages and disadvantages

Hybrid LCA has been presented as a method which provides several advantages. However, it also presents a series of limitations that need to be acknowledged when applying this method (Nakamura and Nansai, 2016).

Distinguishing between the three types of hybrid analysis, firstly, the tiered hybrid analysis presents the strengths of process and IO based approaches and provides reasonably complete and relatively fast inventory results, making the compilation of the inventory relatively quick. On the other hand, this approach can suffer from doublecounting unless material flow analysis is incorporated. This model also deals with the process-based system and the IO-based system separately and so, the interaction between them cannot be assessed in systematic way.

In comparison to the tiered hybrid analysis, the IO based hybrid approach avoids the issue of double-counting, but inherits the limitations of using process data and IOT. The other main disadvantage identified is its difficulty to model the relationship between life cycle phases of a product.

Finally, the integrated hybrid analysis also avoids double-counting, as tiered hybrid approach is not applied. In addition, this method is consistent and complete for upstream processes and the interactions between processes and industries are fully modelled.

\section{Science mapping on the Environmental Footprint}

\subsection{Bibliometric search and a scientometric analysis}

In the context of increasing interest in sustainable production and consumption, the Environmental Footprint concept has gained special attention. To date, little research has been conducted analysing the current state of the EF literature and its trends observed in 
past years. The purpose of this section is to provide a scientometric analysis-based review revealing the insights and evolutionary progress of the Environmental Footprint domain. In order to provide a more comprehensive review approach, a general overview of the evolution of the EF publications from 1992-2018 is presented. In addition, as the LCA is the most accepted tool to conduct the EF studies, a more in-depth investigation of the bibliographic characteristics and co-occurrence of the research regarding the EF applying LCA is included.

The methodology followed consists of a bibliometric search and a scientometric analysis. Bibliometric analysis has been applied by authors to evaluate environmental related areas (Albort-Morant et al., 2017) and in particular, footprint indicators (Y. Zhang et al., 2017). Furthermore, the scientometric analysis is considered as an appropriate method to conduct reviews evaluating research development and performance of authors, countries, institutions, journals, etc. in a certain research domain (Konur, 2012). Combining both approaches provides the capturing and mapping of structural patterns highlighting research hotspots of the studied scientific area (Olawumi and Chan, 2018) (Table 5).

- $\quad$ Bibliometric analysis

For bibliometric analysis, the bibliometric search of the literature was performed in the Web of Science from Thomson Reuters, as it is a well-recognized database and provides high-quality records (Cañas-Guerrero et al., 2013). Two datasets were downloaded: (1) EF dataset and (2) EF and LCA dataset.

For the EF dataset the following parameters were used for data retrieving: Topics="environmental footprint" 
Input-Output Analysis for the quantification of the Environmental Footprint. Case studies in Spain

Timespan="All year"

Database $=$ Science Citation Index Expanded (SCI-E)

Environmental Footprint and LCA dataset parameters:

Topics="environmental footprint" AND "life cycle assessment"

Timespan="All year"

Database $=$ Science Citation Index Expanded (SCI-E)

Altogether, 1,198 original documents were part of the literature set for the EF dataset and 273 publications for the EF and LCA dataset. Each publication included data related to the title, authors, publication year, keywords, countries/territories, institutions, journals, citations, Web of Science categories, pages, and other parameters.

\section{- $\quad$ Science mapping}

The mapping was conducted using VOSViewer. VOSViewer is a text-mining tool developed by van Eck and Waltman (2010), and it is particularly useful for visualizing large networks. It allows a comprehensive bibliometric analysis, as it includes special text mining features, co-occurrence, and co-citation analysis. In addition, it was adopted for this review because of its intuitive data visualization providing distance-based nodes representing the relatedness. In this review, the following steps were carried out using the VOSViewer: (1) Loading of the datasets obtained from the Web of Science, (2) visualization, computation, and analysis of co-citations and (3) visualization, computation and analysis of co-occurrence of keywords, journals and countries. 
Table 5. Bibliometric and Scientometric analysis of the Environmental Footprint dataset and Environmental Footprint and Life Cycle Assessment dataset.

\begin{tabular}{|c|c|}
\hline Literature datasets & Bibliometric and Scientometric Analysis \\
\hline \multirow{3}{*}{ Environmental Footprint dataset } & Characterization of publications \\
\hline & Co-citation \\
\hline & Co-occurrence of keywords \\
\hline \multirow{5}{*}{$\begin{array}{l}\text { Environmental Footprint and } \\
\text { Life Cycle Assessment dataset }\end{array}$} & Characterization of publications \\
\hline & Co-citation \\
\hline & Co-occurrence of keywords \\
\hline & Co-occurrence of publication sources \\
\hline & Co-occurrence of countries \\
\hline
\end{tabular}

\subsection{Overview of the Environmental Footprint}

The literature data retrieved from the Web of Science in relation to the EF consisted of 1,198 records providing information regarding title, authors, type of publication, journal, country and institution, citations, references, keywords and other data. Fig. 1 shows the number of publications of the EF per year. Although in Figure 12 it is not represented due to visualization reasons, the first document was published in 1992. The results show an increasing number of documents over the years reinforcing the fact of the raising awareness among the scientific community. A positive trend is also observed in the number of citations per year (Figure 13). 


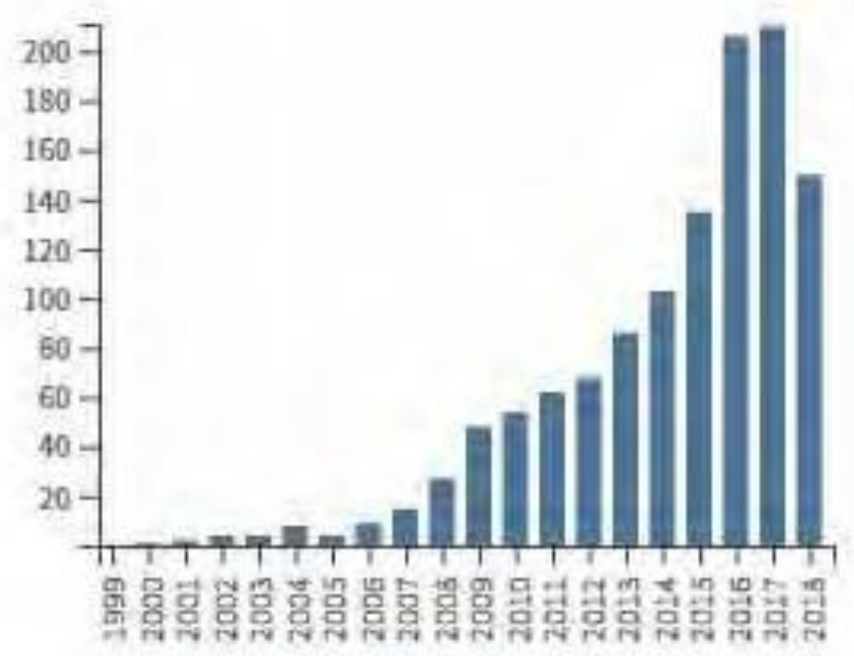

Figure 12. Number of publications per year in the Environmental Footprint field from 1999 to 2018.

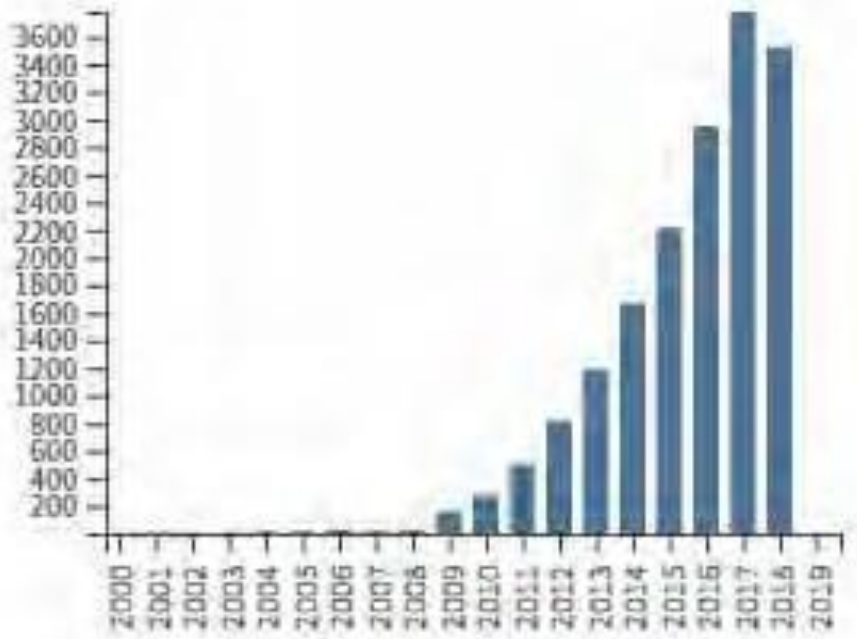

Figure 13. Number of citations per year in the Environmental Footprint field from 1999 to 2018.

The 1,198 documents in the EF area were categorized into eight document types. Articles constituted the main source with 778 (64.93\%), followed by proceeding papers 
with $256(21.36 \%)$, reviews with much less, 100 (8.35\%), book chapters with $39(3.23 \%)$, editorial materials with $16(1.34 \%)$ and the rest of document types (meeting abstracts, letters and news items) accounted for $10(0.79 \%)$.

An overview of the EF is shown in Table 6. As observed with the total number of publications, the total number of authors increased from 1992 to 2018. The total average of authors during this period was 225 and the average per publication was 3.2. On the other hand, it is seen a slight fluctuation of the length of the publications, being the average number of pages per publication 8.6 pages. Although the number of times cited also varied slightly, in general, a rising trend is observed (Figure 14). The total number of times cited was 17,175 and the average per document 19.9. By analyzing the characteristics of the EF publication outputs, it can be concluded that a growth trend is observed in the EF research field over these years.

Table 6. Characteristics by year of publications of the Environmental Footprint field from 1992 to 2018.

\begin{tabular}{|c|c|c|c|c|c|c|c|}
\hline $\begin{array}{c}\text { Published } \\
\text { Year }\end{array}$ & $\begin{array}{c}\text { Total } \\
\text { Publications }\end{array}$ & $\begin{array}{c}\text { Total } \\
\text { Authors }\end{array}$ & $\mathrm{AU} / \mathrm{TP}$ & $\begin{array}{l}\text { Total } \\
\text { Pages }\end{array}$ & PG/TP & $\begin{array}{c}\text { Total Times } \\
\text { Cited }\end{array}$ & TC/TP \\
\hline 1992 & 1 & 1 & 1.0 & 2 & 2.0 & 0 & 0 \\
\hline 1999 & 1 & 4 & 4.0 & 22 & 22.0 & 58 & 58.0 \\
\hline 2000 & 1 & 3 & 3.0 & 4 & 4.0 & 1 & 1.0 \\
\hline 2001 & 2 & 3 & 1.5 & 29 & 14.5 & 40 & 20.0 \\
\hline 2002 & 4 & 12 & 3.0 & 34 & 8.5 & 60 & 15.0 \\
\hline 2003 & 4 & 14 & 3.5 & 35 & 8.8 & 14 & 3.5 \\
\hline 2004 & 8 & 20 & 2.5 & 49 & 6.1 & 181 & 22.6 \\
\hline 2005 & 4 & 7 & 1.8 & 22 & 5.5 & 25 & 6.3 \\
\hline 2006 & 9 & 29 & 3.2 & 11 & 1.2 & 51 & 5.7 \\
\hline 2007 & 15 & 42 & 2.8 & 153 & 10.2 & 561 & 37.4 \\
\hline 2008 & 27 & 98 & 3.6 & 219 & 8.1 & 1403 & 52.0 \\
\hline 2009 & 48 & 152 & 3.2 & 347 & 7.2 & 1350 & 28.1 \\
\hline 2010 & 54 & 172 & 3.2 & 427 & 7.9 & 1751 & 32.4 \\
\hline 2011 & 62 & 227 & 3.7 & 562 & 9.1 & 3915 & 63.1 \\
\hline 2012 & 68 & 248 & 3.6 & 598 & 8.8 & 1120 & 16.5 \\
\hline 2013 & 86 & 320 & 3.7 & 748 & 8.7 & 1682 & 19.6 \\
\hline 2014 & 103 & 387 & 3.8 & 953 & 9.3 & 1945 & 18.9 \\
\hline 2015 & 135 & 493 & 3.7 & 1337 & 9.9 & 1205 & 8.9 \\
\hline 2016 & 206 & 950 & 4.6 & 1899 & 9.2 & 1128 & 5.5 \\
\hline 2017 & 210 & 856 & 4.1 & 1970 & 9.4 & 517 & 2.5 \\
\hline 2018 & 150 & 684 & 4.6 & 1493 & 10.0 & 168 & 1.1 \\
\hline
\end{tabular}

AU/TP: Authors per published document; PG/TP: document length per document number; TC/TP: Citations per published document. 
Input-Output Analysis for the quantification of the Environmental Footprint. Case studies in Spain

Co-citation analysis has been demonstrated to be a useful tool to identify the most influential publications in relation to a certain research area (Trujillo and Long, 2018). Figure 14 displays the publications of the EF field which exhibit the highest citations and link strength. The documents which have the highest influence are the ISO 14044 and ISO 14040. This is explained because both publications are closely related to the environment. ISO 14040 reports the principals and framework of the LCA and ISO 14044 provides general requirements and guidelines of environmental management also related to LCA (ISO 14040, 2006; ISO 14044, 2006).

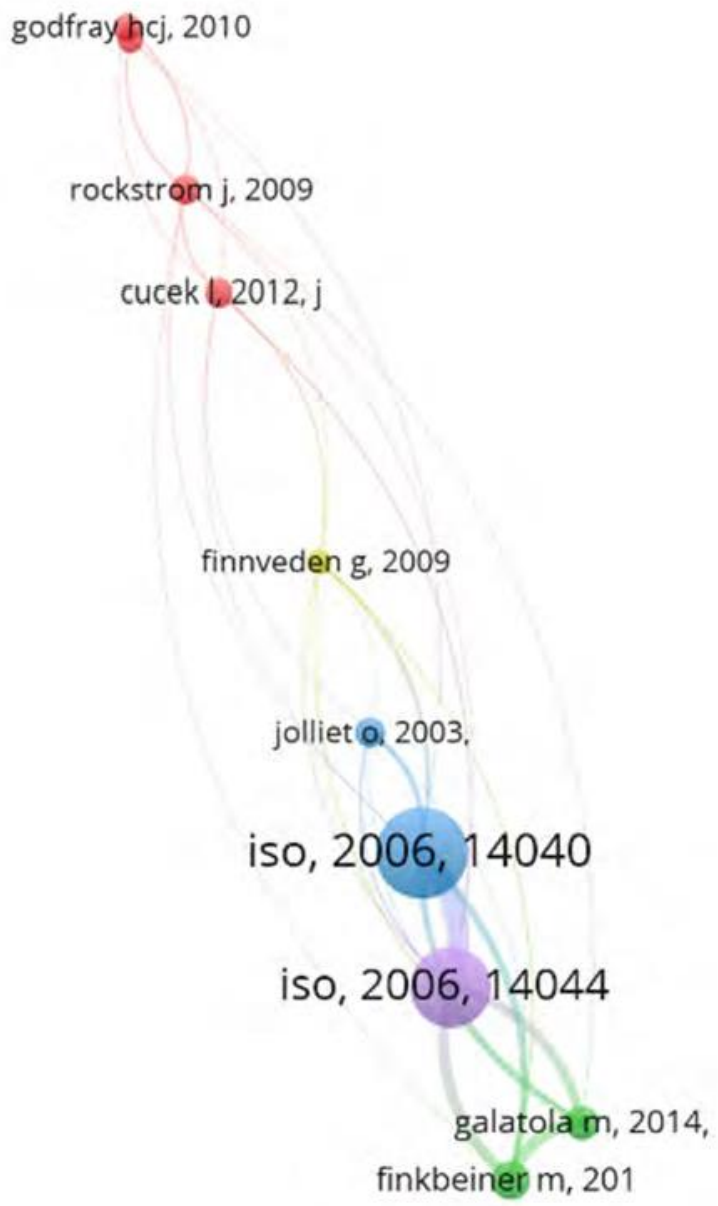

Figure 14. Environmental Footprint document co-citation network (VOSviewer). 
Additionally, the co-occurrence of keywords within the publications is also a key analysis to highlight the main research areas. Figure 15 is a representation of the main topics depicted within the selected field. It uses sizes and distance of nodes and interconnecting lines to show the most frequently studied keywords. The selected terms and their quantitative measurements are summarized in Table 7. In this study, sustainability and life-cycle assessment have the highest values of total link strength and occurrence. This means these keywords are the most inter-related keywords and have the highest degree of frequency within the literature analyzed. On the other hand, when focusing on the influence of the keyword in the research literature, the words greenhouse gas emissions and climate-change show the highest average citations and average normalized citation.

The text mining process also allows for the categorization of the keywords into different clusters. The visualization of the clusters is carried out using different node colors. In this case, five clusters were identified. Keywords promoting sustainability are classified in category 1 . This cluster contains words such as efficiency, energy, performance, management, model, system, water, agriculture, sustainability, and environment. Agriculture seems to be the sector were a green management can be applied to improve the environmental performance. The implementation of new models that are more efficient, such as new water and energy systems, can have positive effects on the environment and promote the overall sustainability of agriculture. Furthermore, cluster 2 refers to research studies related to the EF. Biomass, design, emissions, and optimization are the terms conforming this cluster. The main research studies performed in 2014 in this research area appears to be the optimization of the design in biomass processes with the objective of reducing emissions. Cluster 3 consists of keywords related to greenhouse gas emissions (carbon footprint, climate-change, environmental impacts, greenhouse 
emissions and impact). One of the main indicators to assess the environmental impacts is the carbon footprint, which quantifies the greenhouse emissions generating climatechange issues. This topic has been identified to be one of the current issues that are being addressed worldwide (Mi et al., 2018). Cluster 4 is associated with policy actions. The keywords are environmental footprint, consumption, energy efficiency and framework. As the environmental deterioration is now evident, several countries across the world are focusing their attention on reducing the impacts. In this sense, Europe has promoted the initiative of transitioning to a more sustainable production and consumption by improving energy efficiency and establishing a common framework to assess the impacts known as the Environmental Footprint. Finally, cluster 5 contains methodology keywords, such as LCA, impact assessment, life-cycle assessment, and Product Environmental Footprint. In contrast to other topics, the impact assessment is quite recent and includes the Product Environmental Footprint as an indicator to quantify the environmental performance of goods applying the LCA approach. 
Introduction

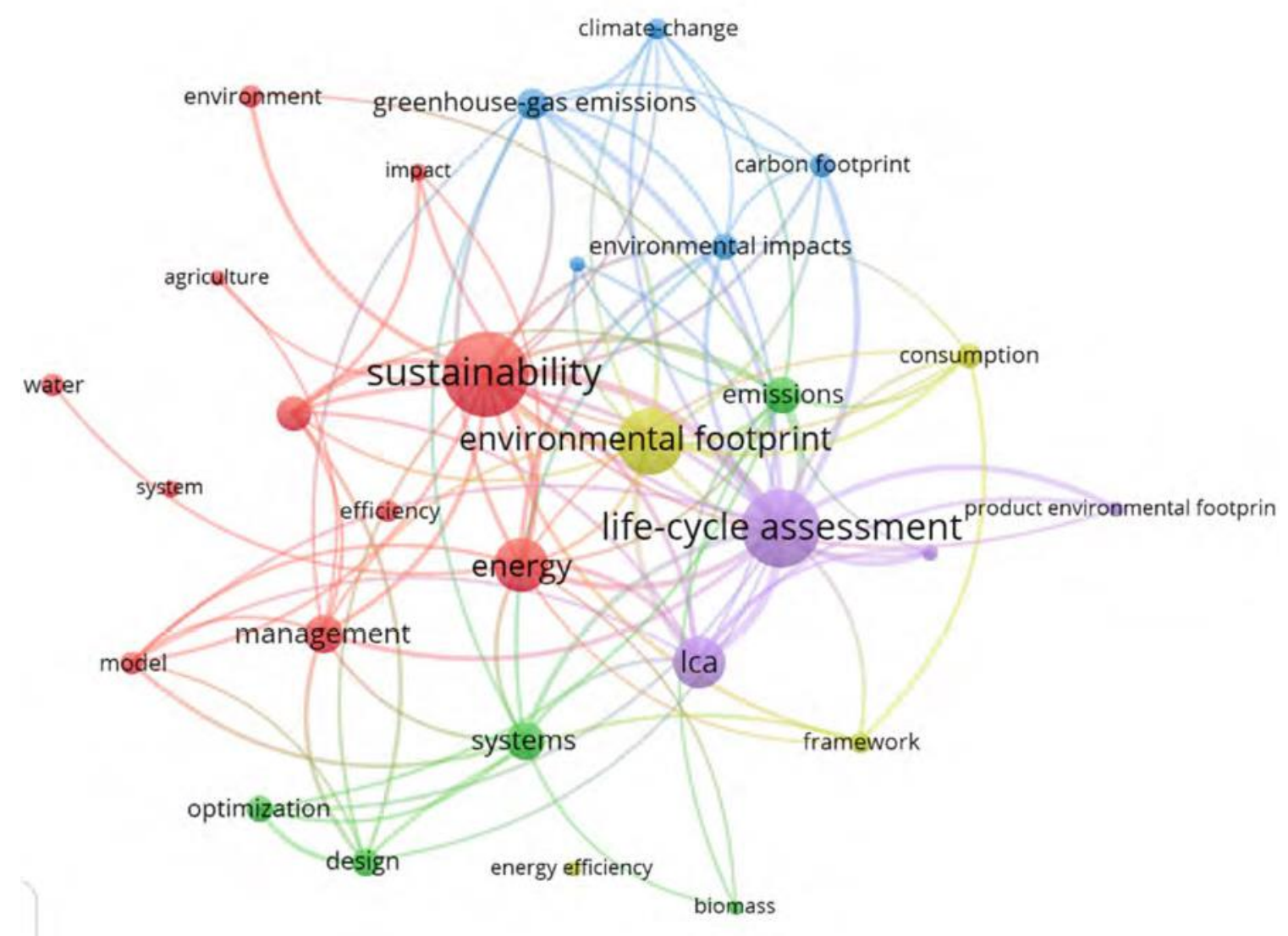

Figure 15. Mapping of keywords in the Environmental Footprint domain (VOS Viewer) 
Input-Output Analysis for the quantification of the Environmental Footprint. Case studies in Spain

Table 7. Co-occurrence of keywords in the Environmental Footprint literature.

\begin{tabular}{|c|c|c|c|c|c|}
\hline Keywords & Occurrence & $\begin{array}{l}\text { Total Link } \\
\text { Strength }\end{array}$ & $\begin{array}{l}\text { Average Year } \\
\text { Published }\end{array}$ & $\begin{array}{l}\text { Average } \\
\text { Citations }\end{array}$ & $\begin{array}{l}\text { Average Norm. } \\
\text { Citation }^{\mathrm{a}}\end{array}$ \\
\hline Life-cycle assessment & 112 & 276 & 2015 & 10 & 1.1 \\
\hline Sustainability & 122 & 203 & 2014 & 12 & 0.9 \\
\hline Environmental footprint & 96 & 161 & 2015 & 10 & 0.8 \\
\hline LCA & 75 & 149 & 2015 & 11 & 0.8 \\
\hline Energy & 78 & 146 & 2015 & 11 & 0.7 \\
\hline Emissions & 54 & 103 & 2015 & 12 & 1.1 \\
\hline Greenhouse gas emissions & 47 & 98 & 2015 & 21 & 1.5 \\
\hline Performance & 50 & 97 & 2015 & 10 & 0.9 \\
\hline Systems & 57 & 97 & 2014 & 9 & 1.1 \\
\hline Management & 57 & 96 & 2014 & 9 & 0.7 \\
\hline Carbon footprint & 35 & 88 & 2015 & 14 & 1.3 \\
\hline Environmental impacts & 38 & 86 & 2015 & 14 & 1.2 \\
\hline Design & 40 & 74 & 2014 & 10 & 0.9 \\
\hline Impact assessment & 23 & 69 & 2015 & 9 & 0.8 \\
\hline Framework & 30 & 65 & 2014 & 8 & 1 \\
\hline Cosumption & 36 & 64 & 2015 & 12 & 1.3 \\
\hline Model & 33 & 64 & 2014 & 13 & 1 \\
\hline Climate-change & 30 & 58 & 2014 & 20 & 1.4 \\
\hline Optimization & 38 & 58 & 2014 & 10 & 0.9 \\
\hline $\begin{array}{l}\text { Product environmental } \\
\text { footprint }\end{array}$ & 24 & 55 & 2015 & 11 & 0.9 \\
\hline Impact & 26 & 51 & 2014 & 15 & 1 \\
\hline Environment & 34 & 45 & 2014 & 16 & 0.9 \\
\hline Efficiency & 33 & 44 & 2015 & 19 & 1.2 \\
\hline Agriculture & 24 & 40 & 2014 & 13 & 1.3 \\
\hline Energyefficiency & 23 & 34 & 2015 & 11 & 0.9 \\
\hline Biomass & 22 & 33 & 2014 & 19 & 1 \\
\hline Water & 34 & 30 & 2014 & 11 & 1.1 \\
\hline
\end{tabular}

a The Average Norm. Citation represents the normalized number of citations of a journal source, article, scholar, a country, or an organization. The calculation consists of dividing the total number of citations by the average number of citations published per year (van Eck and Waltman, 2010). The Average Norm. Citation is also applied in following tables.

\subsection{Environmental Footprint and Life-Cycle Assessment analysis}

The general overview of the publications related to the EF has thrown some light to the main topics related to this field. In order to obtain specific information regarding the EF as an indicator to evaluate human impacts, a more in-depth bibliometric and 
scientometric analysis is carried out. This analysis considers the literature in the research area of the EF and LCA, as this approach has been found to be the main tool to calculate this indicator (Table 7).

With respect to the number of publications of the EF applying an LCA approach a total of 273 publications were retrieved. Among the type of documents, the articles are the main contributors, followed by proceeding papers and reviews (Figure 16). The rest of the publications have little contribution. The characteristics of the publications reveal that 2016 was the key year. This year exhibited the highest number of publications, authors and number of pages (Table 8). It has to be noted in 2004 only one document was published, but it was cited 120 times, which shows the great repercussion of this research. Comparing the publication trend with the EF literature, it is seen that the number of documents decreased in 2017.

Table 8. Characteristics by year of publications of the Environmental Footprint and Life Cycle Assessment field from 1992 to 2018.

\begin{tabular}{|c|c|c|c|c|c|c|c|}
\hline $\begin{array}{c}\text { Published } \\
\text { Year }\end{array}$ & $\begin{array}{c}\text { Total } \\
\text { Publications } \\
\end{array}$ & $\begin{array}{c}\text { Total } \\
\text { Authors } \\
\end{array}$ & AU/TP & Total Pages & $\mathrm{PG} / \mathrm{TP}$ & $\begin{array}{c}\text { Total limes } \\
\text { Cited }\end{array}$ & $\mathrm{TC} / \mathrm{TP}$ \\
\hline 2000 & 1 & 3 & 3.0 & 4 & 4.0 & 1 & 1.0 \\
\hline 2002 & 1 & 3 & 3.0 & 7 & 7.0 & 4 & 4.0 \\
\hline 2004 & 1 & 4 & 4.0 & 7 & 7.0 & 120 & 120.0 \\
\hline 2005 & 1 & 1 & 1.0 & 12 & 12.0 & 0 & 0 \\
\hline 2006 & 1 & 3 & 3.0 & 10 & 10.0 & 0 & 0 \\
\hline 2007 & 1 & 2 & 2.0 & 10 & 10.0 & 63 & 63.0 \\
\hline 2008 & 3 & 12 & 4.0 & 36 & 12.0 & 101 & 33.7 \\
\hline 2009 & 3 & 10 & 3.3 & 22 & 7.3 & 157 & 52.3 \\
\hline 2010 & 5 & 19 & 3.8 & 32 & 6.4 & 100 & 20.0 \\
\hline 2011 & 11 & 48 & 4.4 & 109 & 9.9 & 281 & 25.5 \\
\hline 2012 & 11 & 48 & 4.4 & 83 & 7.5 & 201 & 18.3 \\
\hline 2013 & 21 & 72 & 3.4 & 185 & 8.8 & 501 & 23.9 \\
\hline 2014 & 25 & 106 & 4.2 & 218 & 8.7 & 408 & 16.3 \\
\hline 2015 & 27 & 98 & 3.6 & 265 & 9.8 & 225 & 8.3 \\
\hline 2016 & 63 & 304 & 4.8 & 705 & 11.2 & 423 & 6.7 \\
\hline 2017 & 50 & 215 & 4.3 & 520 & 10.4 & 169 & 3.4 \\
\hline 2018 & 48 & 228 & 4.8 & 527 & 11.0 & 59 & 1.2 \\
\hline
\end{tabular}

A U/TP: Authors per published document; PG/TP: document length per document number; TC/TP: Citations per published document. 


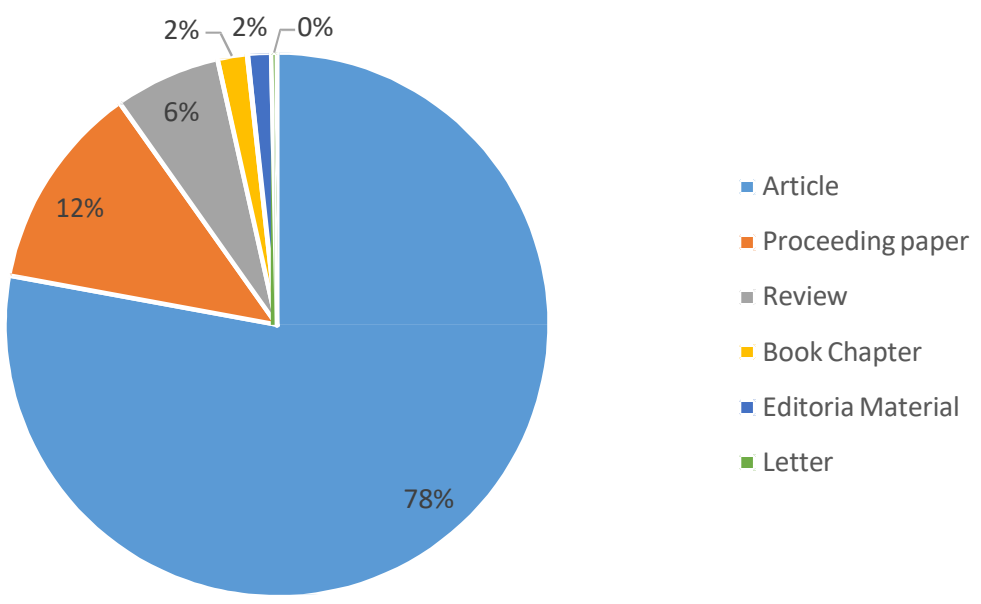

Figure 16. Distribution of the types of documents the Environmental Footprint and Life Cycle Assessment field from 2000 to 2018.

The analysis of the publications that were most co-cited revealed similar findings as with the EF database. Both ISO documents (14040 and 14044) were the publications with the highest impact in the research community. Following these policy documents, research articles from Finkbeiner (2014) and Galatola and Pant (2014) were found with the highest number of links and were the most co-cited articles. 


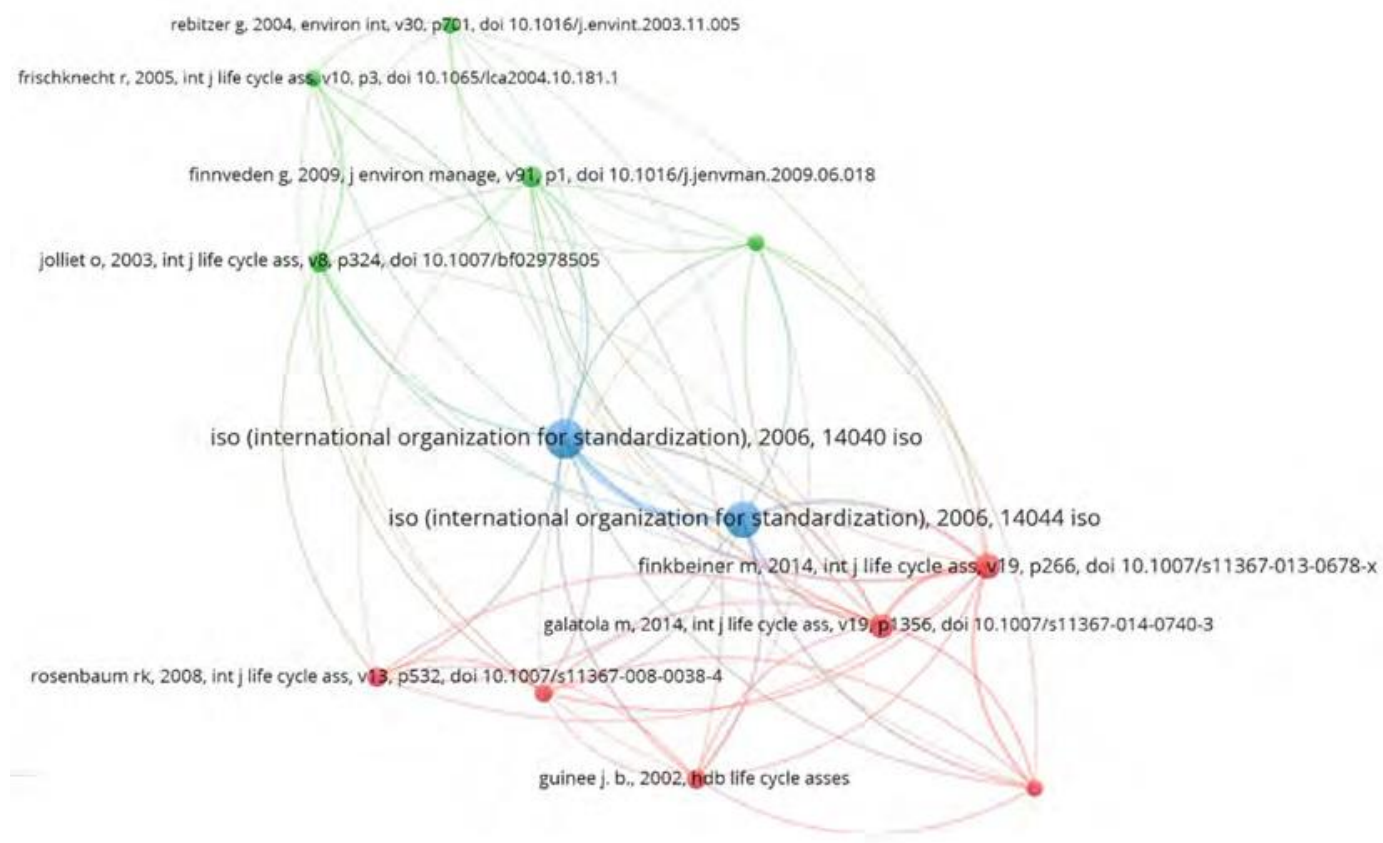

Figure 17. Environmental Footprint and Life Cycle Assessment document co-citation network (VOSviewer).

For the EF and LCA domain, the most frequently used keywords were similar to the wider EF database (Figure 18). These keywords were grouped in four clusters which resembled the seven clusters mentioned for the EF analysis. Cluster 1 included keywords referring to policy implementation (breakdown, impact assessment, LCA, policy implementation and Product Environmental Footprint), as it was also seen for the EF cooccurrence analysis. Cluster 2 (carbon footprint, impacts, management, products, and sustainability) is associated with sustainability. Since its development, the carbon footprint has served as an indicator calculating the impacts of products and providing valuable measures to implement in the supply chain management to promote sustainability (Alvarez and Rubio, 2015). Cluster 3 shows terms (energy, environmental impacts, greenhouse gas emissions, and systems) related to the sources of environmental impacts. Energy systems appear to be the main contributors to greenhouse emissions leading to increasing environmental impacts. Finally, cluster 4 can be identified with the 
meaning of EF. The keywords in this cluster are emissions, Environmental Footprint, lifecycle assessment, and performance. Taking the definition from the European Commission, the Environmental Footprint aims at "establishing a common methodological approach to enable Member States and the private sector to assess, display and benchmark the environmental performance of products, services, and companies based on a comprehensive assessment of environmental impacts over the lifecycle" (European Commission, 2012).

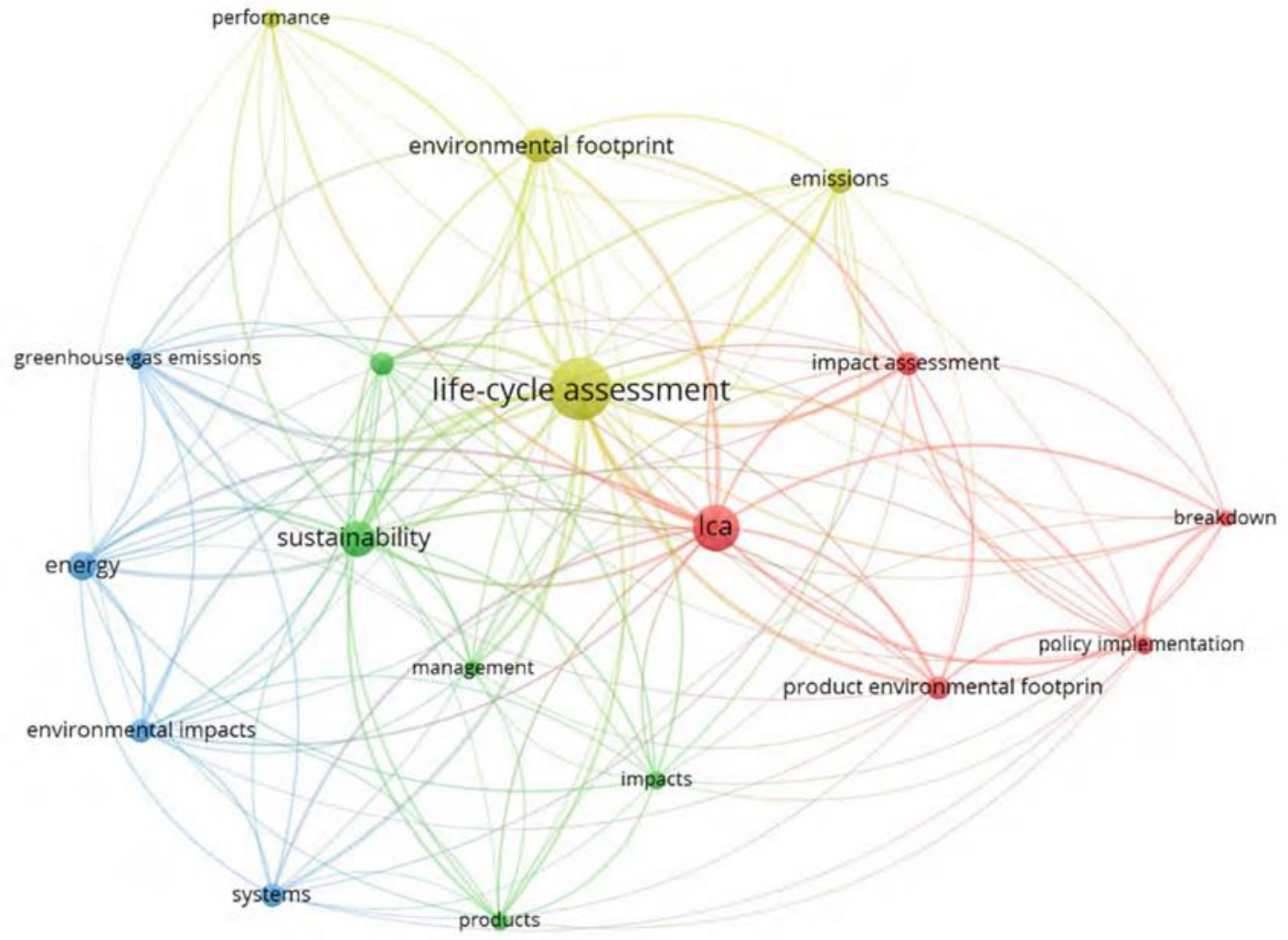

Figure 18. Mapping of keywords in the Environmental Footprint and Life Cycle Assessment domain (VOSviewer).

More details of the highlighted keywords are presented in Table 9. According to the average year in which the documents were published, it is seen that the EF applying 
the LCA is a topic which burst in 2015 and 2016. Contrary to what it was seen in the EF domain, for the EF and LCA field, the climate change topic has not aroused that much attention, in fact, the greenhouse emissions keyword had a low value of average normalized citation. On the other hand, in the field of EF and LCA, it seems that the study of the EF as an indicator of impact assessment has caught the attention of researchers in recent years. This emerging topic appears to be a direction to follow for future research towards the quantification of environmental impacts to improve products' and services' performance.

Table 9. Co-occurrence of keywords in the Environmental Footprint and Life Cycle Assessment literature.

\begin{tabular}{lccccc}
\hline \multicolumn{1}{c}{ Keywords } & Occurrence & $\begin{array}{c}\text { Total } \\
\text { Link } \\
\text { Strength }\end{array}$ & $\begin{array}{c}\text { Average } \\
\text { Year } \\
\text { Published }\end{array}$ & $\begin{array}{c}\text { Average } \\
\text { Citations }\end{array}$ & $\begin{array}{c}\text { Average } \\
\text { Norm. } \\
\text { Citation }\end{array}$ \\
\cline { 1 - 3 } Life-cycle assessment & 112 & 235 & 2015 & 10 & 0.9 \\
LCA & 68 & 133 & 2015 & 10 & 0.8 \\
Sustainability & 45 & 117 & 2015 & 8 & 0.8 \\
Environmental footprint & 40 & 94 & 2015 & 11 & 1.0 \\
Energy & 32 & 75 & 2014 & 9 & 0.8 \\
Carbon footprint & 22 & 64 & 2015 & 5 & 0.5 \\
Impact assessment & 21 & 61 & 2016 & 10 & 1.1 \\
Product environmental footprint & 21 & 59 & 2016 & 10 & 0.7 \\
Emissions & 25 & 58 & 2015 & 8 & 0.7 \\
Environmental impacts & 23 & 58 & 2016 & 9 & 1.0 \\
Green-house gas emissions & 16 & 52 & 2016 & 5 & 0.6 \\
Policy implementation & 14 & 51 & 2016 & 4 & 0.7 \\
Systems & 21 & 43 & 2015 & 11 & 0.8 \\
Breakdown & 13 & 40 & 2016 & 5 & 0.6 \\
Management & 13 & 40 & 2015 & 9 & 0.9 \\
Impacts & 15 & 38 & 2015 & 8 & 1.1 \\
Products & 14 & 36 & 2015 & 5 & 0.8 \\
Performance & 14 & 34 & 2015 & 9 & 1.0 \\
\hline
\end{tabular}

Moreover, Figure 19 visually represents the main source journals where the EF and LCA documents were published. Ten journals were selected as the most influential sources and their quantitative measurements are summarized in Table 10. The sizes and 
links of the nodes show the closeness referred to the frequencies that publications from journals cite each other. Various colors are assigned to distinguish between journal clusters, which define the degree of interrelatedness of mutual citation (Jin et al., 2019). Journals grouped in the same cluster tend to have a higher level of mutual citation. For example, International Journal of Life Cycle Assessment has the highest link strength and it is close-related to Sustainability. However, journals from different clusters could also present a high level of correlation, such as International Journal of Life Cycle Assessment and Journal of Cleaner Production. Additionally, the parameters total link strength, number of articles, and total citations provide insights into the level of productivity. Whereas, average citation per document and the average normalized citation are parameters expressing the influence of a journal in the research community (Jin et al., 2018). In this sense, highly productive journals do not necessarily mean they have a high significance in the research area. In this study, it is found that International Journal of Life Cycle Assessment and Journal of Cleaner Production are the most productive journals in terms of number of publications and citations. However, in terms of significance, Science of the Total Environment and Resources Conservation and Recycling stand out. 


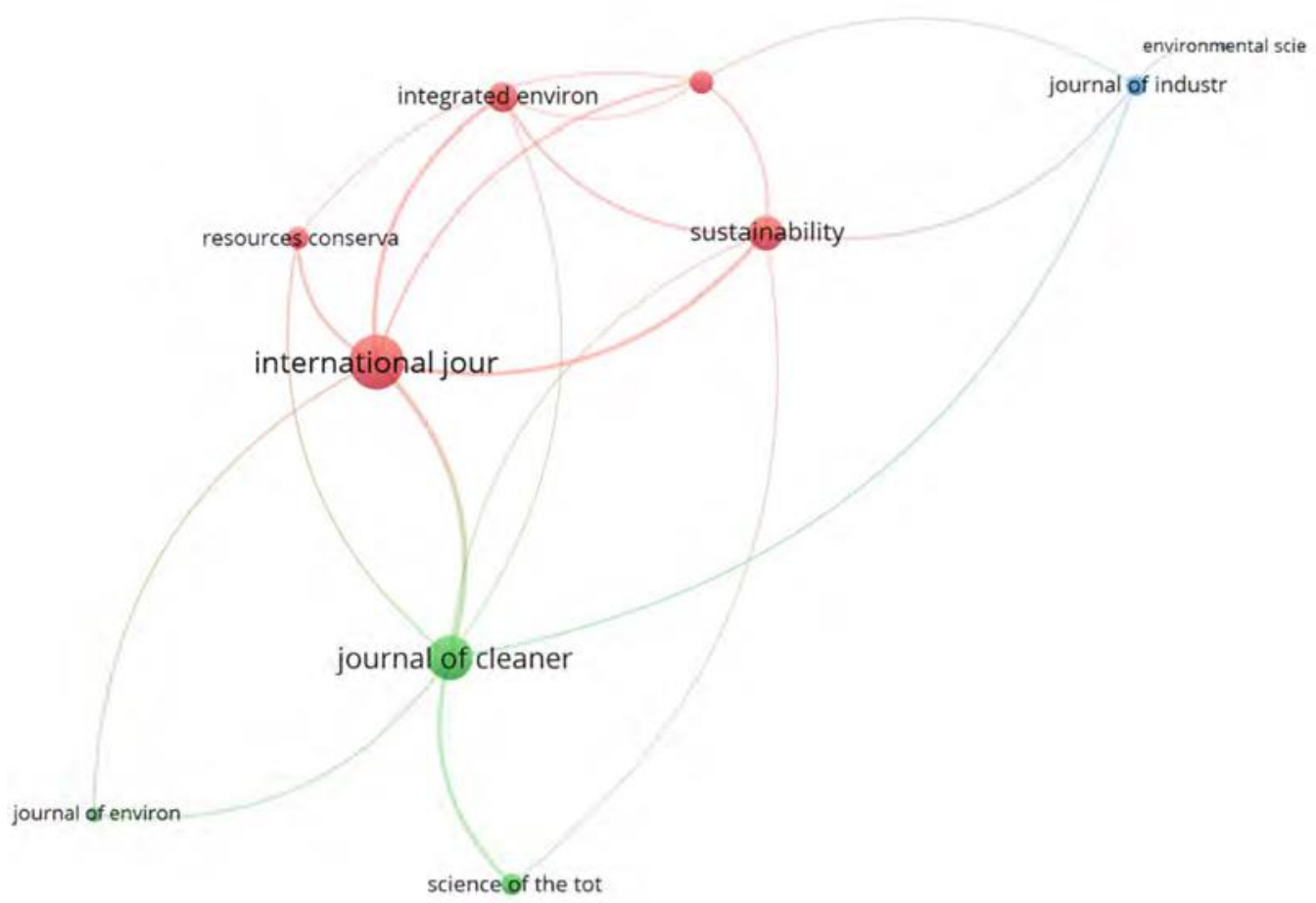

Figure 19. Mapping of journal sources in the Environmental Footprint and Life Cycle Assessment domain (VOSviewer).

Table 10. Co-occurrence of journal sources in the Environmental Footprint and Life Cycle Assessment literature.

\begin{tabular}{|c|c|c|c|c|c|c|}
\hline Journal Source & $\begin{array}{l}\text { Number of } \\
\text { publications }\end{array}$ & $\begin{array}{l}\text { Total } \\
\text { Link } \\
\text { Strength }\end{array}$ & $\begin{array}{c}\text { Average } \\
\text { Year }\end{array}$ & $\begin{array}{c}\text { Total } \\
\text { citations }\end{array}$ & $\begin{array}{l}\text { Average } \\
\text { Citations }\end{array}$ & $\begin{array}{l}\text { Average } \\
\text { Norm. } \\
\text { Citation }\end{array}$ \\
\hline $\begin{array}{l}\text { International Journal } \\
\text { of Life Cycle } \\
\text { Assessment }\end{array}$ & 31 & 33 & 2015 & 382 & 11 & 1.1 \\
\hline Journal of Cleaner & & & & & & \\
\hline Production & 52 & 24 & 2016 & 464 & 10 & 1 \\
\hline Sustainability & 7 & 16 & 2015 & 59 & 8 & 0.9 \\
\hline $\begin{array}{l}\text { Integrated } \\
\text { Envrironmental } \\
\text { assessment and }\end{array}$ & 4 & 12 & 2015 & 18 & 5 & 0.6 \\
\hline $\begin{array}{l}\text { Environmental } \\
\text { Engineering and } \\
\text { Management } \\
\text { Journal }\end{array}$ & 4 & 8 & 2016 & 14 & 6 & 0.7 \\
\hline
\end{tabular}


Input-Output Analysis for the quantification of the Environmental Footprint. Case studies in Spain

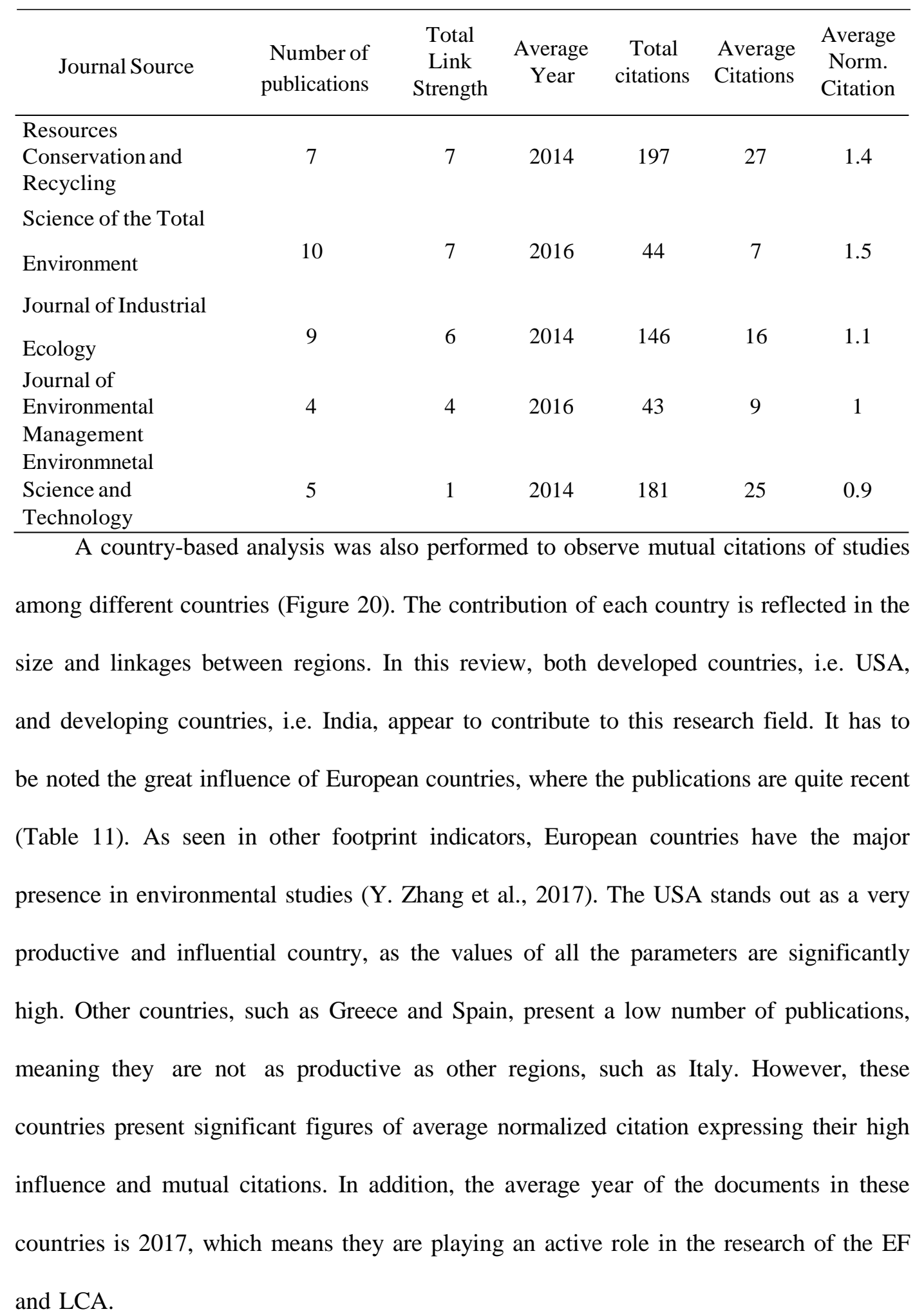




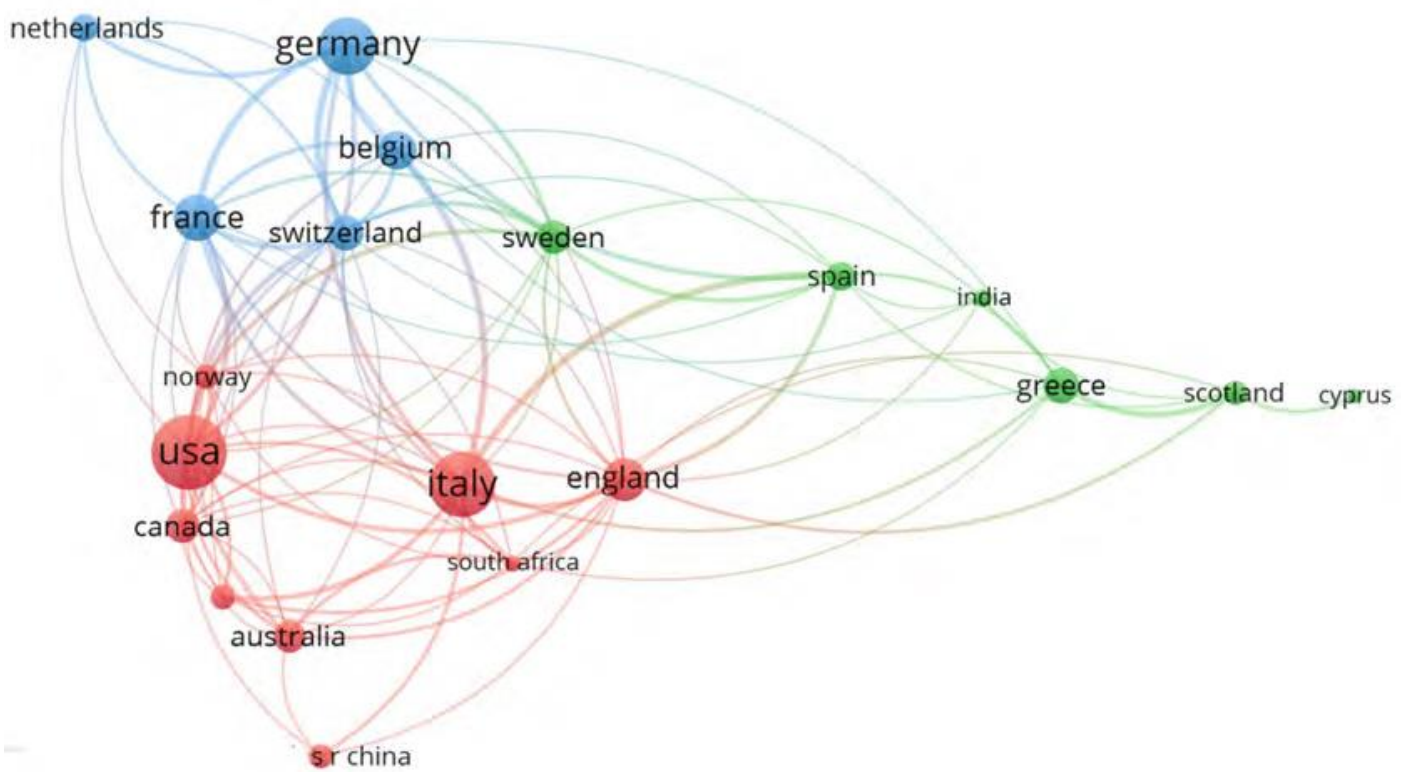

Figure 20. Mapping of countries in the Environmental Footprint and Life Cycle Assessment domain (VOSviewer).

Table 11. Co-occurrence of countries in the Environmental Footprint and Life Cycle Assessment literature.

\begin{tabular}{|c|c|c|c|c|c|c|}
\hline Country & $\begin{array}{l}\text { Number of } \\
\text { publications }\end{array}$ & $\begin{array}{l}\text { Total Link } \\
\text { Strength }\end{array}$ & $\begin{array}{c}\text { Average } \\
\text { Year }\end{array}$ & $\begin{array}{c}\text { Total } \\
\text { citations }\end{array}$ & $\begin{array}{l}\text { Average } \\
\text { Citations }\end{array}$ & $\begin{array}{c}\text { Average } \\
\text { Norm. } \\
\text { Citation } \\
\end{array}$ \\
\hline Italy & 42 & 35 & 2015 & 251 & 5 & 0.7 \\
\hline Switzerland & 17 & 33 & 2016 & 127 & 7 & 0.8 \\
\hline Germany & 35 & 32 & 2016 & 239 & 6 & 1.4 \\
\hline USA & 51 & 32 & 2014 & 1100 & 15 & 1.5 \\
\hline France & 26 & 31 & 2016 & 239 & 9 & 0.8 \\
\hline England & 23 & 28 & 2015 & 296 & 12 & 0.7 \\
\hline Belgium & 20 & 23 & 2016 & 163 & 8 & 0.6 \\
\hline Spain & 13 & 21 & 2017 & 54 & 5 & 1.0 \\
\hline Sweden & 16 & 21 & 2015 & 121 & 8 & 1.0 \\
\hline Norway & 10 & 15 & 2014 & 157 & 14 & 0.8 \\
\hline Australia & 15 & 14 & 2014 & 230 & 15 & 0.8 \\
\hline $\begin{array}{l}\text { South } \\
\text { Africa }\end{array}$ & 6 & 14 & 2014 & 31 & 5 & 1.2 \\
\hline Canada & 16 & 13 & 2015 & 110 & 6 & 0.8 \\
\hline Denmark & 10 & 13 & 2015 & 160 & 14 & 1.0 \\
\hline Greece & 17 & 12 & 2017 & 156 & 10 & 1.2 \\
\hline Scotland & 10 & 11 & 2017 & 55 & 4 & 1.4 \\
\hline Netherlands & 12 & 10 & 2016 & 67 & 4 & 0.8 \\
\hline India & 7 & 5 & 2017 & 10 & 4 & 0.6 \\
\hline China & 10 & 5 & 2016 & 25 & 5 & 0.7 \\
\hline Cyprus & 5 & 2 & 2016 & 43 & 8 & 1.4 \\
\hline
\end{tabular}




\section{Objectives}

\subsection{Main objective}

The aim of this $\mathrm{PhD}$ thesis is to build on growing literature on the interrelationships between economic systems and the environment, as well as, to obtain the impacts derived from these relationships. Following this objective, this study evaluates the EF as a useful indicator and its calculation based on the environmentally-extended multi-regional inputoutput (EEMRIO) method. A series of case studies will be presented in order to analyze the $\mathrm{EF}$ of the economic sectors and household consumption and be able to assess their environmental performance.

\subsection{Specific objectives}

The main objective will be achieved by obtaining the EF through the EEMRIO method of the following case studies:

- Primary sector: peri-urban organic orchard.

- Secondary sector: multilayer wood parquet industry.

- Tertiary sector: conservation and maintenance service of a river.

- Household consumption: EF by source of Spanish household consumption.

- Methodological advance: Hybrid-MRIO method applied to the removal of a largescale infrastructure.

These case studies will allow these specific objectives:

a) Present and analyze the EF as a multi-criteria indicator.

b) Carry out a more in-depth study of the EF by identifying the main contributing 
sectors and regions through the application of the EEMRIO method.

c) Estimate the environmental impacts, direct and indirect, associated with the economic activities developed in the case studies.

d) Identify opportunities and measures to reduce the environmental impacts of the different systems.

\subsection{Chapters' description and justification}

\subsubsection{Introduction}

This first chapter is a general presentation of the global environmental changes occurring in the planet. The concept of sustainable development was introduced as a key target that needs to be addressed nowadays. In order to implement measures, the EF was developed to serve as a reliable indicator. In addition, the different methods for calculating this indicator are described, including their benefits and limitations. A scientometric analysis and mapping review is also included to show the status quo and research trend in the domain of the $\mathrm{EF}$ and provide valuable information for researchers and practitioners in this field.

\subsubsection{Materials and methods}

This chapter includes the theoretical and practical bases of the IO method applied in this thesis. It describes the specific application of the EEMRIO method and the use of the multi-regional input-output (MRIO) database EXIOBASE2 to calculate the inter-linkages between sectors and countries and the environmental impacts. 


\subsubsection{Results}

In this chapter five case studies are presented to evaluate the application of the EF by means of the environmentally-extended input-output method. Three of them are based on the assessment of the environmental performance of the economic sectors, the primary sector, the secondary sector and the tertiary or services sector. The EF would also be assessed from the consumption perspective reflected in the national household consumption of Spain. Finally, a fifth study related to the removal of a large-scale infrastructure is included to analyze the environmental impacts applying a hybrid-MRIO method. This section includes the five research papers that have been published or are being reviewed in well-recognized journals and included in the 2017 Journal Citation Reports.

\section{a) Primary sector: The Environmental Footprint of an organic peri-urban orchard network}

The aim of this study is to prove the application of this indicator in an agricultural system. The interest in new production schemes and the initiative of sustainable cities have led to the emergence of organic peri-urban orchards. In order to evaluate the environmental performance of these systems, this investigation is carried out in seven orchards. The EEMRIO approach is applied to identify the most polluting sectors of this system to find environmentally-friendly solutions. This research paper has been published in the journal of Science of the Total Environment. 


\section{b) Secondary sector: Organization Environmental Footprint applying a multi-} regional input-output analysis: A case study of a wood parquet company in Spain

This case study is presented to assess the OEF of a wood business. Fourteen impact categories related to the environment are obtained using the EXIOBASE2 database and the EEMRIO method. The annual activity of this company is used to assess its environmental performance and implement measures to reduce the impacts generated. This research paper has been published in the journal of Science of the Total Environment.

c) Tertiary sector: Organisation Environmental Footprint through input-output analysis. Case study in the construction sector

In this investigation the environmental impacts originated from the works done from an awarded public tender concerning the conservation and maintenance service of the urban waterfront and riverside of the Manzanares River in Madrid (Spain) are presented. The most influential sectors of each impact category and regional and sectorial linkages for climate change are identified. Additionally, the environmental impacts generated in this company's supply chain are also obtained. From the results obtained, recommendations for the implementation of the OEF and new measures to reduce the environmental impacts are provided. This research paper has been published in the journal of Industrial Ecology.

d) Household consumption: Environmental Footprint by source of supply chains from Spanish household consumption

Europe's transition to a sustainable economy relies on the implementation of policies 
developed by its member states. In light of this fact, the EF is an indicator capable of providing valuable information of the impacts at the national level. This case study is the first attempt of combining a national Consumer Expenditure Survey data with a global MRIO database to obtain the evolution of the EF generated in the supply chains from the consumption of households. It is believed that the calculation of this multi-criteria indicator will favor the implementation of national policies and regulations. This research paper is under revision in the journal of Global Environmental Change.

\section{e) Methodological advance: The Environmental Footprint of the end-of-life phase of a dam through a hybrid-MRIO analysis}

In this study, a hybrid-MRIO approach is applied to quantify the EF related to the end-of-life phase of a dam. The analysis included the combination of primary activity data, such as fuel and electricity consumption, with the economic expenditure to obtain more accurate and reliable results. The calculation of the environmental impacts is carried out considering the direct impacts, related to the on-site combustion of fossil fuels and the impacts from purchased electricity, and the indirect impact generated by upstream and downstream activities in the supply chain. This case study intends to provide valuable data to shed light on the environmental performance of constructions regarding the endof-life phase. This research paper has been published in the journal of Building and Environment.

\subsubsection{Discussion}

This chapter examines and evaluates the strengths, weaknesses, opportunities and threats identified in the EF. This indicator presents a series of strengths and opportunities, which aim at providing a robust tool related to the environment. However, there are 
weaknesses and threats that need to be addressed for further implementation of this indicator. In addition, the applicability of the EF by means of the EEMRIO method also presents some limitations that need to be acknowledged.

\subsubsection{Conclusions}

In this chapter, the conclusions drawn by the case studies are highlighted. These remarks relate to the functionality of the $\mathrm{EF}$ as a comprehensive and useful indicator to assess the environmental impacts from human activities. It is also outlined the applicability of the EEMRIO method as a valid and robust method for the calculation of the EF. Further research areas are also suggested. 



\section{MATERIAL AND METHODS}





\section{Method overview}

The challenge of representing the complex economic structure of each country in a simplified way was faced by economists worldwide. The first attempt of developing this idea was the French economist François Quesnay, who published the "Tableau Économique" in 1758 (Charles, 2003). In this study, Quesnay presented the way a farmer distributed his profit at the same time as he was buying the required agricultural products. It is the first study that shows the interdependence between sectors, which in this case, three sectors were used representing the French economy (Miller and Blair, 1985).

Nearly a century after the investigation of Quesnay, Leon Walras developed a system of simultaneous equations representing the demand for goods by consumers, the supply of goods by producers, and the equilibrium condition that supply equal demand on every market (Walras, 1874). However, it was several years after when Walras' generalized model was recognized as a relevant contribution in the economic field.

In 1936, the Russian economist Wassily Leontief (1905-1999) working at Harvad University, developed IO models of the United States economy (Leontief, 1936). Five years after, his first work "The Structure of the American Economy, 1919-1939” was published (Leontief, 1941). The models used included the inputs required to produce a unit of output in each economic sector. This modeling of the U.S. economy enabled the tracing the direct and indirect inputs in each sector.

Leontief introduced assumptions which allowed the simplification of Walras' equations and thus, the empirical implementation of a theory of general equilibrium. The four simplifications applied to the input-output model were:

- Homogeneity: only one output by sector was considered, so that the initial Walras' number of output was reduced. This simplification considers that each sector produces a single output with a single input structure and that the technology 
applied is constant.

- Proportionality and fixed coefficients: fixed proportionality between the inputs required and the level of output of each sector was also established.

- Linearity of coefficients: this assumption implies absence of economies of scale and that the total effect of carrying out production in several sectors is the sum of the separate effects.

- Infinite and elasticity supply: unrestricted productive capacity is also assumed.

It was stated that the main contribution of Leontief's work was the combination of theorization and empiricism in a way in which the theoretical concept of economic interdependence was equipped with empirical foundations. For his work, Leontief received the Nobel Prize in economics in 1973.

The IO method continues to evolve thanks to the contribution of economists, such as the Nobel Prize winner Richard Stone. The increasing availability of high-speed computers has also favored the reduction in the calculation time. Additionally, this method has been used to implement the System of National Accounts of the United Nations and Eurostat. Nowadays, each member state has to develop their National Accounts following the rules of the European System of Accounts, which establishes guidelines in order to obtain reliable and comparable statistics of the economic structure of each country.

\section{Input-output analysis}

The IO model is an economic tool which enables the calculation of the economic effects, direct and indirect, derived from the variation in the final demand of goods and services. The basic IO model is generally constructed from observed economic data for a specific system or geographic region which describes the economic flows between a 
sector known as the producer and another sector known as the buyer (Miller and Blair, 1985). These economic activities are referred to a specific period of time. The inputoutput model requires three main steps: construction of the IOT, derivation of the technical coefficients and identification of impacts by means of the multiplier effect.

\subsection{Input-output table}

IO model is based on the accounting framework of a geographic region at the national, regional or multi-regional level. This accounting framework consists of a series of interrelated tables in which different economic activities are grouped in activity branches. Usually, public institutions are in charge of the development and management of these tables.

To build the IOT, also known as the transactions table or symmetric IOT, two types of tables are needed: the supply and use tables (Table 12). Supply tables provide the supply of goods and services by domestic production and imports, while use tables provide the use of goods and services for intermediate consumption and final use (consumption, gross capital formation, exports), as well as, how the components of value added (compensation of employees, other net taxes on production, consumption of fixed capital, net operating surplus) are generated by industries in the domestic economy. Thus, supply and use tables give detailed information on the production processes, the interdependencies in production, the use of goods and services and generation of income generated in production. After balancing, supply and use tables provide coherent data linking industries, products and sectors (Eurostat, 2008). 
Table 12. Supply and Use tables.

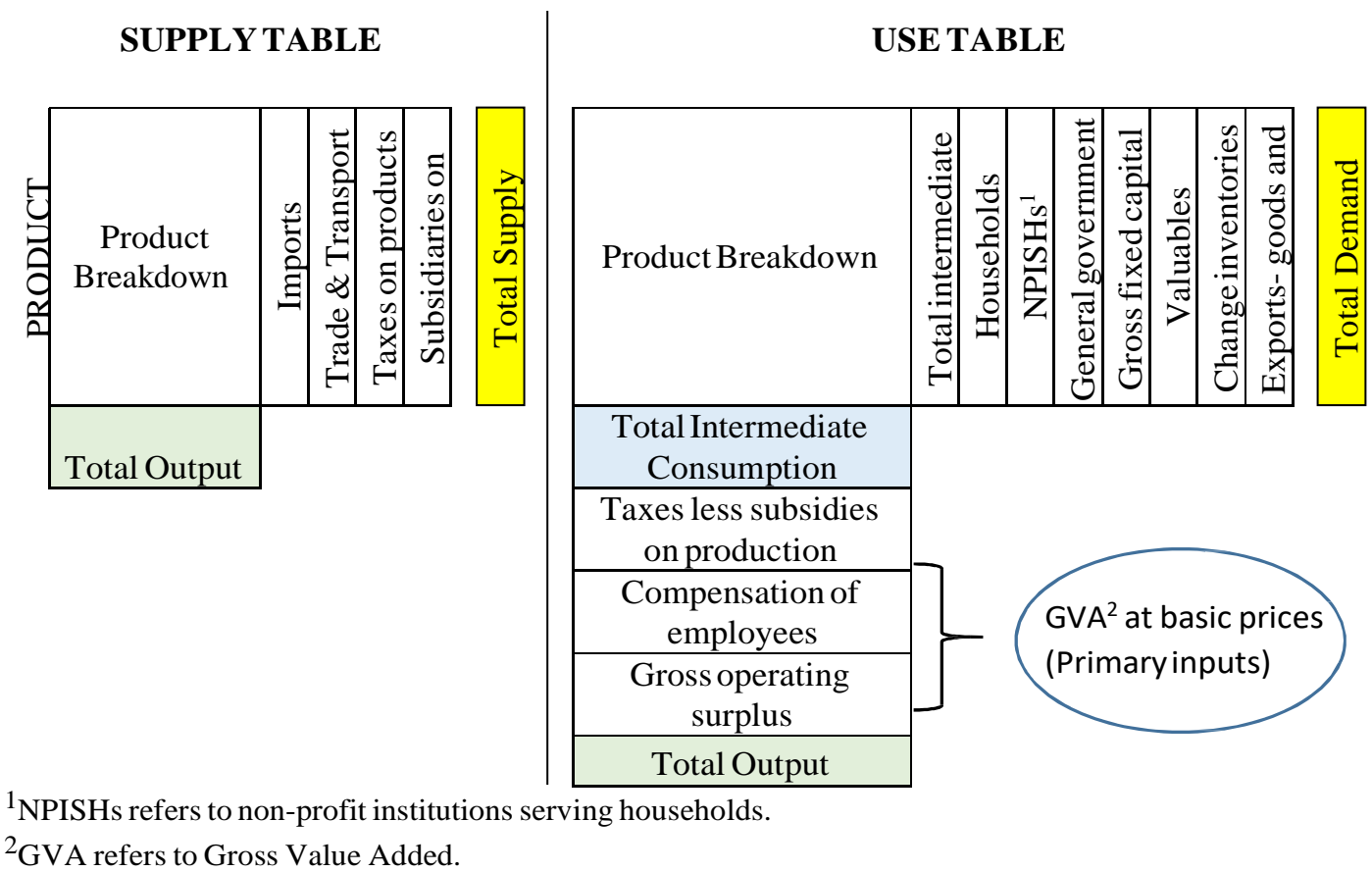

The combination of the above tables results in the IOT in which the economic flows within an economic system during a particular base year are computed. However, supply and use tables are not symmetric because there are sectors that produce more than one type of product, and products or services that are generated by more than one activity sector. Therefore, certain assumptions are needed between supply and use tables. These hypothesis are:

- Product technology assumption: Each product is produced in its own specific way, irrespective of the industry where it is produced.

- Industry technology assumption: Each industry has its own specific way of production, irrespective of its product mix.

- Fixed industry sales structure assumption: Each industry has its own specific sales structure, irrespective of its product mix.

- Fixed product sales structure assumption: Each product has its own specific sales structure, irrespective of the industry where it is produced. 
To sum up, IOT show how each industry consumes a certain mix of products in order to produce its output, and how each product is sold to a variety of domestic industries and final markets. The mathematical structure consists of $n$ linear equations that can be represented in the matrix form. The columns refer to the production cost of each activity sector, including intermediate costs and value added. The rows represent the way the activity production has been distributed between the different possible uses. Table 13 shows an example of an IOT, where the columns show the inputs of each activity sector and the rows show the outputs. In the IOT in monetary terms (in which the values are at current prices), the row and column totals are equal, as well as, the total of the row sums equals the total of the column sums.

Table 13. Simplified input-output table.

\begin{tabular}{|c|c|c|c|c|c|}
\hline \multirow[b]{2}{*}{ Production of sectors } & \multicolumn{4}{|c|}{ Purchases from sectors } & \multirow{2}{*}{$\begin{array}{c}\text { Total } \\
\text { Production } X \\
\end{array}$} \\
\hline & 1 & 2 & 3 & $\mathrm{n}$ & \\
\hline 1 & \multirow{4}{*}{$\begin{array}{l}X_{11} \\
X_{21} \\
X_{31} \\
X_{n 1}\end{array}$} & \multirow{4}{*}{$\begin{array}{l}X_{12} \\
X_{22} \\
X_{32} \\
X_{n 2}\end{array}$} & \multirow{4}{*}{$\begin{array}{l}X_{13} \\
X_{23} \\
X_{33} \\
X_{n 3}\end{array}$} & \multirow{4}{*}{$\begin{array}{l}X_{1 n} \\
X_{2 n} \\
X_{3 n} \\
X_{n n}\end{array}$} & $X_{1}$ \\
\hline 2 & & & & & $X_{2}$ \\
\hline 3 & & & & & $X_{3}$ \\
\hline $\mathrm{n}$ & & & & & $X_{\mathrm{n}}$ \\
\hline Intermediate Consumption $I$ & $I_{1}$ & $I_{2}$ & $I_{3}$ & $I_{n}$ & \\
\hline Value added $V$ & $V_{1}$ & $V_{2}$ & $V_{3}$ & $V_{\mathrm{n}}$ & \\
\hline Total Production $X$ & $X_{1}$ & $X_{2}$ & $X_{3}$ & $X_{\mathrm{n}}$ & \\
\hline
\end{tabular}


The total output for all sectors can be estimated by the system of $n$ linear equations:

\section{Equation 1}

$$
\begin{gathered}
\mathrm{x}_{11}+\mathrm{x}_{12}+\mathrm{x}_{13}+\cdots+\mathrm{x}_{1 \mathrm{n}}=\mathrm{x}_{1} \\
\mathrm{x}_{21}+\mathrm{x}_{22}+\mathrm{x}_{23}+\cdots+\mathrm{x}_{2 \mathrm{n}} \equiv \mathrm{x}_{22} \\
\mathrm{x}_{31}+\mathrm{x}_{33}+\cdots+\mathrm{x}_{3 \mathrm{n}}=\mathrm{x}_{3} \\
\cdots \\
\mathrm{x}_{\mathrm{n} 1}+\mathrm{x}_{\mathrm{n} 2}+\mathrm{x}_{\mathrm{n} 3}+\cdots+\mathrm{x}_{\mathrm{nn}}=\mathrm{x}_{\mathrm{n}}
\end{gathered}
$$

\subsection{Technical Coefficients}

Once the IOT is prepared, the next step required for the IO model is to estimate the 'input' or 'technical' or 'technological' coefficient matrix. This matrix describes the sectoral technologies in terms of the required inputs per unit of output. The technical coefficients $\left(a_{i j}\right)$ can be expressed as:

\section{Equation 2}

$$
\mathrm{a}_{\mathrm{ij}}=\mathrm{x}_{\mathrm{ij}} / \mathrm{X}_{\mathrm{j}}
$$

Where $a_{i j}$ is the technical or technological coefficient defined as the delivery from sector $i$ to $j$ per unit of sector's $j$ output. $X j$ is the total output production and $x i j$ is the quantity of products from sector $i$ used in sector $j$ to obtain the production $X j$.

Equation 2 can also be expressed as:

\section{Equation 3}

$$
x_{i j}=a_{i j} X_{j}
$$


Substituting Equation 3 in Equation 1, the total output production of a specific sector can be represented as:

\section{Equation 4}

$$
\mathrm{X}_{1}=\mathrm{a}_{11} \mathrm{X}_{11}+\mathrm{a}_{12} \mathrm{X}_{2}+\cdots+\mathrm{a}_{1 \mathrm{n}} \mathrm{X}_{\mathrm{n}}
$$

And generalizing Equation 4, a system of $n$ (linear) simultaneous equations (each one describing the distributions of one sector's product through the economy) representing the productive system of a country is as follows:

\section{Equation 5}

$$
\begin{gathered}
X_{2} \equiv \underset{a_{21}}{a_{11} X_{1}}+\underset{a_{22}}{a_{12} X_{2}}+\cdots \neq \underset{a_{2 n} X_{n}}{a_{1 n} X_{n}} \\
\cdots \\
X_{n}=a_{n 1} X_{1}+a_{n 2} X_{2}+\cdots+a_{n n} X_{n}
\end{gathered}
$$

This set of linear equations can also be represented in a matrix form (Equation 6).

\section{Equation 6}

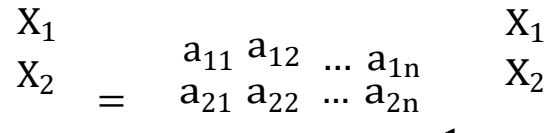

$$
\begin{aligned}
& \begin{array}{lllll}
\ldots & \ldots & 1 & \ldots
\end{array} \\
& \begin{array}{llllll}
X_{n} & a_{n 1} & a_{n 2} & \cdots & a_{n n} & X_{n}
\end{array}
\end{aligned}
$$

Equation 6 expressed in a simpler way results as: 


\section{Equation 7}

$$
\mathrm{X}=\mathrm{AX}
$$

Where $A$ is the Technical Coefficient Matrix.

However, the final production of a sector not only includes the intermediate demand from sectors, the demand of goods and services used for consumption and not forming part of any other production process has to be considered as well. This demand corresponds to the final demand and has to be added to Equation 8 .

\section{Equation 8}

$$
\mathrm{X}=\mathrm{AX}+\mathrm{Y}
$$

This set of equations explicit the dependence of the total outputs of each sector on the inter-industry flows and the final demand of that sector in an economic system (Miller \& Blair, 2009). If the set of technological coefficients is considered fixed and known, this set of equations can be solved by either specifying the set of total outputs or specifying the set of final demands (Proops et al., 1993).

The new IOT including the final demand $(Y)$ will be represented as follows in Table 14. 
Table 14. Input-output table.

\begin{tabular}{|c|c|c|c|c|c|c|}
\hline \multirow[b]{2}{*}{ Production of sectors } & \multicolumn{4}{|c|}{ Purchases from sectors } & \multirow{2}{*}{$\begin{array}{c}\text { Final } \\
\text { demand } \\
Y\end{array}$} & \multirow{2}{*}{$\begin{array}{c}\text { Total } \\
\text { Production } \\
X\end{array}$} \\
\hline & 1 & 2 & 3 & $n$ & & \\
\hline 1 & \multirow{4}{*}{$\begin{array}{l}x_{11} \\
x_{21} \\
x_{31} \\
x_{n 1}\end{array}$} & \multirow{4}{*}{$\begin{array}{l}x_{12} \\
x_{22} \\
x_{32} \\
x_{n 2}\end{array}$} & \multirow{2}{*}{$X_{13}$} & $X_{1 n}$ & $Y_{1}$ & $X_{1}$ \\
\hline 2 & & & & $x_{2 n}$ & $Y_{2}$ & $x_{2}$ \\
\hline 3 & & & $X_{33}$ & $x_{3 n}$ & $Y_{3}$ & $x_{3}$ \\
\hline $\mathrm{n}$ & & & $x_{n 3}$ & $x_{n n}$ & $Y_{\mathrm{n}}$ & $x_{n}$ \\
\hline Intermediate Consumption I & $I_{1}$ & $I_{2}$ & $I_{3}$ & $I_{n}$ & & \\
\hline Value Added V & $V_{1}$ & $V_{2}$ & $V_{3}$ & $V_{\mathrm{n}}$ & GDP & \\
\hline Total Production $X$ & $x_{1}$ & $x_{2}$ & $x_{3}$ & $x_{n}$ & & \\
\hline
\end{tabular}

As the final demand is usually assumed to be exogenous, the previous equation can be rearranged to:

\section{Equation 8}

$$
X=(1-A)^{-1} Y
$$

Where $(1-A)^{-1}$ is known as the 'Leontief inverse' or the total requirements matrix, shows all direct and indirect requirements for production in the economy in order to satisfy a certain final demand (Miller and Blair, 2009).

\subsection{Multiplier effect}

The IO analysis allows the assessment of changes that occur in the activity sectors of the economy as a result of variations in the demand of goods and services. An exogenous shock in the final demand of one sector can cause a long chain of interactions in the production processes. This long chain of interactions is known as the multiplier effect, where the increase in the inputs requirements from one sector also causes the 
increase in the outputs from the supply sectors.

The economist Ralph George Hawtrey developed the concept of the multiplier effect in the 30's and it has been used to justify government decisions, such as public expenditure and tax benefits. In order to calculate the multiplier effect, it is necessary to distinguish between:

- Direct effects: effects created directly in the industry being measured or invested in.

- Indirect effects: effects belonging to the upstream supply-chain effects resulting from the direct effect.

The multiplier effect is the ratio between the total effects (direct and indirect) and the money effect. The 'Leontief inverse' matrix can be decomposed to obtain the direct and indirect effects. Equation 8 can be decomposed as:

\section{Equation 9}

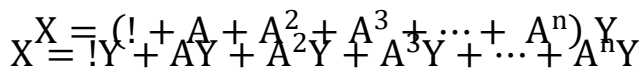

$I Y$ : calculates the direct (first order) effect of the final demand.

$A Y$... AnY: calculates the indirect requirements to meet the final demand. These impacts are the rest of the impacts generated in the supply chain.

Once these parameters have been calculated, the multiplier effect of a final demand variation can be calculated as follows: 


\section{Equation 10}

$$
E m=\frac{Y}{\left(! Y+A Y+\cdots+A^{n} Y\right)}
$$

\section{Environmentally-extended input-output analysis and Multi-regional environmentally-extended input-output analysis}

As previously mentioned, IO analysis was established as a useful tool used in the economic field. Other application fields were also considered by different authors. In 1970, economist Wassily Leontief published a research paper presenting a new approach named environmentally extended input-output (EEIO) analysis to assess the amount of pollution associated with given levels of production and consumption (Leontief, 1970). He proposed adding a new row and column to the technical coefficient matrix $A$, so that each new coefficient described the quantity of pollutant generated per monetary unit of each production sector. With the new matrix, the process calculation was the same as with a traditional IO analysis, calculating the Leontief inverse and then calculate the amount of direct and indirect impacts generated from a certain final demand (Miller and Blair, 1985).

\subsection{Environmentally-extended input-output analysis}

Leontief's approach for obtaining the environmental impacts was widely accepted among the scientific community. However, this approach of considering the environmental effects as an endogenous variable in the IO model was an issue at the time due to the limited computational capacity to solve such complex equations. In order to overcome this limitation, the environmental effects were considered as exogenous 
variables. The IO model would include an external vector containing the environmental effects of each sector per total production unit of the same sector (Lave et al., 2002). The IO model would then be defined with the following expression:

\section{Equation $11 \quad M_{i}=R_{i} X=R_{i}(1-A)^{-1} Y$}

$M_{i}$ are the direct and indirect environmental effects associated to a production $X$ which satisfies a change in the final demand $Y .(I-A)^{-1}$ is Leontief's inverse matrix which describes the direct and indirect requirements per production unit of each activity sector. $\mathrm{Y}$ is the final demand and $R_{i}$ is the environmental vector describing the environmental effect $i$ per unit of production of each activity sector.

The EEIO analysis considers that the environmental effects generated by a certain sector is proportional to the production of that same sector. An increase in the final demand of a good or service will lead to an increase in the production sector which supplies that good or service. At the same time, the intermediate sectors involved in providing inputs to the main sector will also generate environmental impacts which will be taken into consideration. In this way, the environmental impacts will be extended to the entire national accounting.

In the 90's, the EEIO analysis was introduced as a suitable approach to analyze the environmental impacts from a life cycle perspective. As mentioned, the IOTs gather the entire economic transactions involved in the national accounting, these are the economic flows between sectors. Adding the environmental vector allows the calculation of the environmental impacts, as all the processes, from the acquisition of raw materials to the production of the demanded good, have been taken into consideration. The concept of 
IO-LCA was first introduced by the Green Design Group from the Civil Engineering and Environment Department of Carnegie Mellon University in Pittsburgh. It was then when the IO analysis was presented as an alternative method to the traditional process-based method applied in LCA. Since then, the IO method has been applied in numerous cases to obtain the environmental impacts (Ali et al., 2017; Dias et al., 2014).

\subsection{Multi-regional environmentally-extended input-output analysis}

In order to describe the complex net of global economic relationships and their environmental consequences, the EEMRIO analysis was established. This model was presented by Lenzen et al. (2004) and has been applied in many studies (de la Rua and Lechon, 2016; Reutter et al., 2017). This approach is similar to the environmentallyextended input-output analysis, with the difference of including several regions and sectors associated to these regions.

The MRIO table can be understood as the combination of single IO tables (Table 16). Each column of the MRIO table shows the industry requirements from the domestic and foreign sectors to deliver a good or service from a specific sector in a certain country. This means that if there is a final demand in country A, which buys a domestically produced good, the impacts generated also consider any intermediate flows from countries B and $\mathrm{C}$ that are used to produce the goods in country A that are consumed in country A.

Some of the MRIO databases are Eora, EXIOBASE, Global Trade Analysis Project (GTAP) and World Input-Output Database (WIOD) (Table 15) (Tarne et al., 2018). 
Input-Output Analysis for the Quantification of the Environmental Footprint. Case studies in Spain

Table 15. Overview of the main MRIO databases.

\begin{tabular}{|c|c|c|c|c|c|}
\hline $\begin{array}{c}\text { MRIO } \\
\text { database }\end{array}$ & $\begin{array}{r}\text { Region } \\
\text { detail }\end{array}$ & $\begin{array}{l}\text { Sector } \\
\text { detail }\end{array}$ & Time series & $\begin{array}{l}\text { Coverag } \\
\text { e of } \\
\text { global } \\
\text { GDP } \\
\end{array}$ & Extensions \\
\hline Eora $^{1}$ & 190 & 26 & $1990-2015$ & $\approx 100 \%$ & $\begin{array}{l}\text { Energy, emissions, water } \\
\text { and land footprints, } \\
\text { employment }\end{array}$ \\
\hline EXIOBASE $^{2}$ & 49 & 163 & 1995-2011 & $>90 \%$ & $\begin{array}{l}\text { Over } 100 \text { extensions } \\
\text { including energy, emissions, } \\
\text { water and land footprints, } \\
\text { employment }\end{array}$ \\
\hline GTAP $^{3}$ & 140 & 57 & $\begin{array}{c}1990, \\
1992, \\
1995, \\
1997,2001, \\
2004, \\
2007,2011\end{array}$ & $>98 \%$ & $\begin{array}{l}\text { Emissions, employment, } \\
\text { land use }\end{array}$ \\
\hline WIOD $^{4}$ & 43 & 35 & $1995-2014$ & $>85 \%$ & $\begin{array}{l}\text { Emissions, employment, } \\
\text { water, land and resource use }\end{array}$ \\
\hline
\end{tabular}

${ }^{1}$ http://worldmrio.com/

${ }^{2}$ https://www.exiobase.eu/

${ }^{3}$ https://www.gtap.agecon.purdue.edu/databases/v9/default.asp

${ }^{4}$ http://www.wiod.org/home 
Table 16. Environmentally-extended multi-regional input-output framework.

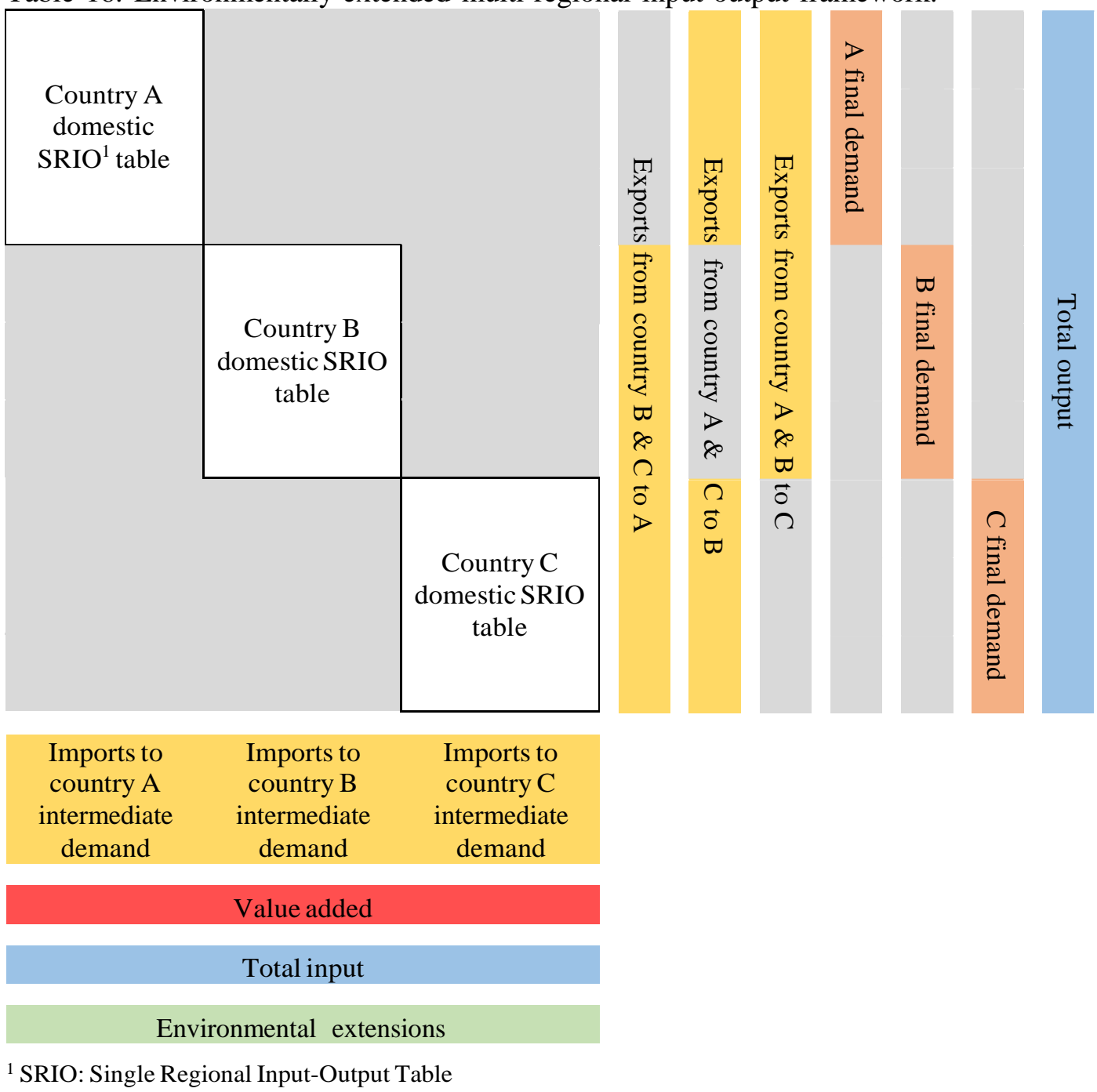

\subsection{Multi-regional environmentally-extended input-output analysis: EXIOBASE}

The EEMRIO analysis describes the direct and indirect environmental impacts as a result of a final demand of goods or services throughout the entire supply chain.

The calculation of these impacts is defined by the previously-mentioned Equation 11:

$$
M_{i}=R_{i} X=R_{i}(1-A)^{-1} Y
$$

$M_{i}$ are the direct and indirect environmental impacts associated to a production that 
satisfies a change in the final demand. $(I-A)^{-1}$ is the Leontief's inverse matrix, which describes the direct and indirect requirements per unit of production of each sector. $\mathrm{Y}$ is the final demand and $R_{i}$ is the environmental vector, which describes the environmental impact $I$ per unit of production for each sector.

In order to obtain the environmental impacts, it is necessary to determine each of the components of Equation 11. $A$ is the technical coefficient matrix obtained from the database EXIOBASE2. This MRIO database is a global EEMRIO database based in 2007 and currently available without cost. The EXIOBASE2 database was built from supply and use tables data from Eurostat for $27 \mathrm{EU}$ countries and data for 16 additional countries from various sources. It considers 43 countries (covering more than 90 percent of global GDP) and the missing countries were covered in 5 additional "Rest of the World" regions. The main reason for using EXIOBASE2 to study the environmental impacts in this thesis relies on the fact that EXIOBASE2 has a clear environmental and resource focus with high levels of detail in both the product and industry classifications, resulting in 200 products and 163 industries (Wood et al., 2015).

The environmental vector $R_{i}$ denotes the environmental stressors representing each impact category, such as land use, water depletion, and climate change, per unit output of each product-region combination (Steinmann et al., 2018). $R_{i}$ is obtained by multiplying the characterization factors of each impact category by the environmental accounts (Table 17). EXIOBASE2 database contains environmental accounts for emissions, resources and materials, while the characterization factors used were obtained from an impact assessment method for LCA. In our case study, the International Reference Life Cycle Data System (ILCD) on its version 1.04 for 14 midpoint impact categories were used (JRC European commission, 2011). However, since the number of environmental substances in EXIOBASE2's inventory is limited, not all of the characterization factors 
in ILCD were used. In those cases were no substances were available in EXIOBASE2, the characterization factors were excluded. In addition, the impact category ionizing radiation was excluded due to the absence of characterization factors in ILCD.

Table 17. Obtained environmental vectors $R_{i}$ using the characterization factors from ILCD and the corresponding environmental accounts from EXIOBASE2. The numbers in parenthesis represent the matrix dimensions (rows x columns).

\begin{tabular}{|c|c|c|c|}
\hline Impact category & Characterization factors & Type of account & $\begin{array}{c}\text { Environmental } \\
\text { vector } \\
\end{array}$ \\
\hline Climate change & Cfcc $(1 \times 170)$ & $\begin{array}{c}\text { Emission } \\
\text { Q_em } \\
(170 \times 7824)\end{array}$ & $\begin{array}{c}\text { Cfcc*QQem } \\
(1 \times 170)\end{array}$ \\
\hline Ozone depletion & Cfod $(1 \times 170)$ & $\begin{array}{c}\text { Emission } \\
\text { Q_em } \\
(170 \times 7824)\end{array}$ & $\begin{array}{l}\text { Cfod *Q_em } \\
\quad(1 \times 170)\end{array}$ \\
\hline $\begin{array}{c}\text { Human toxicity- cancer } \\
\text { effects }\end{array}$ & Cfht (1x170) & $\begin{array}{c}\text { Emission } \\
\text { Q_em } \\
(170 \times 7824)\end{array}$ & $\begin{array}{l}\text { Cfht *Q_em } \\
(1 \times 170)\end{array}$ \\
\hline $\begin{array}{c}\text { Human toxicity-non-cancer } \\
\text { effects }\end{array}$ & Cfhtn (1x170) & $\begin{array}{c}\text { Emission } \\
\text { Q_em } \\
(170 \times 7824)\end{array}$ & $\begin{array}{l}\text { Cfhtn *Q_em } \\
\quad(1 \times 170)\end{array}$ \\
\hline Acidification & Cfac $(1 \times 170)$ & $\begin{array}{c}\text { Emission } \\
\text { Q_em } \\
(170 \times 7824)\end{array}$ & $\begin{array}{l}\text { Cfac* Q_em } \\
(1 \times 170)\end{array}$ \\
\hline Particulate matter & Cfpm (1x170) & $\begin{array}{c}\text { Emission } \\
\text { Q_em } \\
(170 \times 7824)\end{array}$ & $\begin{array}{l}\text { Cfpm *Q_em } \\
\quad(1 \times 170)\end{array}$ \\
\hline Fresh water Ecotoxicity & Cffre $(1 \times 170)$ & $\begin{array}{c}\text { Emission } \\
\text { Q_em } \\
(170 \times 7824)\end{array}$ & $\begin{array}{l}\text { Cffre * Q_em } \\
\quad(1 \times 170)\end{array}$ \\
\hline Photochemical oxidation & Cfpo (1x170) & $\begin{array}{c}\text { Emission } \\
\text { Q_em } \\
(170 \times 7824)\end{array}$ & $\begin{array}{l}\text { Cfpo *Q_em } \\
(1 \times 170)\end{array}$ \\
\hline Eutrophication- terrestrial & Cfeut (1x170) & $\begin{array}{c}\text { Emission } \\
\text { Q_em } \\
(170 \times 7824)\end{array}$ & $\begin{array}{l}\text { Cfeut* Q_em } \\
\quad(1 \times 170)\end{array}$ \\
\hline Eutrophication- freshwater & Cfeuf $(1 \times 170)$ & $\begin{array}{c}\text { Emission } \\
\text { Q_em } \\
(170 \times 7824)\end{array}$ & $\begin{array}{l}\text { Cfeuf } * \text { Q_em } \\
\quad(1 \times 170)\end{array}$ \\
\hline Eutrophication-marine & Cfeum $(1 \times 170)$ & $\begin{array}{c}\text { Emission } \\
\text { Q_em } \\
(170 \times 7824)\end{array}$ & $\begin{array}{l}\text { Cfeum *Q_em } \\
(1 \times 170)\end{array}$ \\
\hline Land use & Cfland (1x15) & $\begin{array}{c}\text { Resources } \\
\text { Q_re }(15 \times 7824)\end{array}$ & $\begin{array}{l}\text { Cfland * Q_re } \\
\qquad(1 \times 15)\end{array}$ \\
\hline Resource depletion-Water & Cfwd (1x170) & $\begin{array}{c}\text { Material } \\
\text { Q_em } \\
(284 \times 7824)\end{array}$ & $\begin{array}{l}\text { Cfwd * Q_mat } \\
\qquad(1 \times 170)\end{array}$ \\
\hline $\begin{array}{l}\text { Resource depletion- mineral, } \\
\text { fossil }\end{array}$ & Cfmd (1x284) & $\begin{array}{c}\text { Material } \\
\text { Q_em } \\
(284 \times 7824) \\
\end{array}$ & $\begin{array}{l}\text { Cfmd * Q_mat } \\
\quad(1 \times 284)\end{array}$ \\
\hline
\end{tabular}





\section{RESULTS}





\section{Primary sector: The Environmental Footprint of an organic peri-urban orchard network}

[See research paper already published in Appendix 1] 



\section{Secondary sector: Organization Environmental} Footprint applying a multi-regional input-output analysis: A case study of a wood parquet company in Spain

[See research paper already published in Appendix 2] 



\section{Tertiary sector: Organisation Environmental Footprint through input-output analysis. Case study in the construction sector}

[See research paper already published in Appendix 3] 



\section{Household consumption: Environmental Footprint by source of supply chains from Spanish household consumption}

[See research paper under review in Appendix 4] 



\section{Methodological advance: The Environmental Footprint of the end-of-life phase of a dam through a hybrid-MRIO analysis}

[See research paper already published in Appendix 5] 



\section{DISCUSSION}



The Communication "Building the Single Market for Green Products" published by the European Commission in 2013 was the starting point to establish a common methodological approach to define environmentally sustainable products and organizations. This Communication proposed the PEF and the OEF as two suitable approaches for assessing and displaying their environmental performance.

In order to test the practicability of these approaches, the EF pilot phase was conducted between 2013 and 2017 to test the process for developing product- and sectorspecific rules and the way of communicating the environmental performance to business partners, consumers and other company stakeholders.

The EF was established as an ambitious initiative that presents a series of strengths and opportunities, which aims at providing a robust methodology related to the environment. However, the practical application of this methodology has also shed light to some weaknesses and threats that need to be addressed for further implementation of this indicator. To identify these aspects, the SWOT (strengths, weaknesses, opportunities and threats) analysis is a strategic management tool that provides information regarding the internal (strengths and weaknesses) and external factors (opportunities and threats) related to a topic (Berariu and Mihaela, 2011). Figure 21 shows the StrengthsWeaknesses-Opportunities-Threats (SWOT) analysis performed for the EF. 
Input-Output Analysis for the quantification of the Environmental Footprint. Case studies in Spain

\section{SWOT analysis}

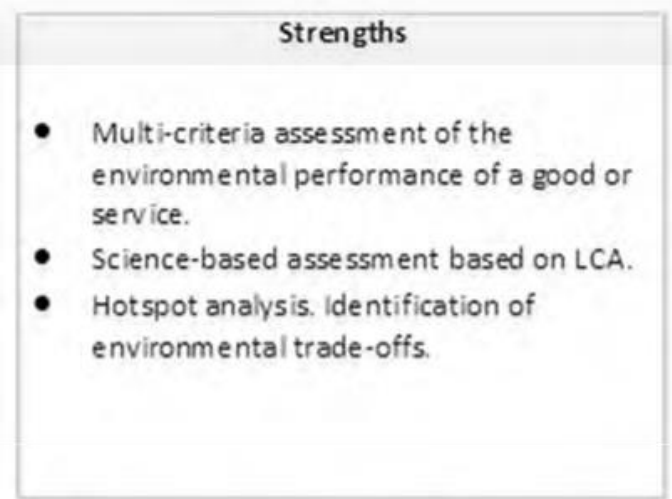

\section{Opportunities}

- To establish a harmonized product and organiz ation assessment.

- The EF, together with the development of PEFCRs, put a strong focus on comparability and benchmarking.

- Enhance competitiveness, green growth, and innovation among organizations. Harmonised reference for brand environmental claims and marketing.

\section{Weaknesses}

- EF does not consider social and econom ic dimensions.

- Ecosystem functions, biodiversity or toxicity are not well captured by the EF.

- Methodological issues derived from the immaturity of EF.

\section{Threats}

- Differences and conflicts of PEF and OEF with existing standards: confusion and prolferation.

- New approach with new term inology: mistrust and communication issues among consumers.

- The de manded data quality and cutoff criteria: massive workload increasing costs and reducing its applicability for SMEs.

\section{Recommendations}

- Consider the combination of EF methodology with social LCA.

- Include re levant environmental impacts by using complementary approaches.

- Use scientifically valid and internationally agreed and tested life cycle impact assessment categories and methods.

- Propose further investigation to correctly define the product and organization categories used in PEFCRs and OEFCRs to allow comparison.

- EF methodology should be built based on solid standards. Conflicts between both approaches should be avoided to cre ate a harmonized methodology.

- Efforts should be directed in simplifying the terminology for communicating environmental information.

- A revaluation of data requirements should be studied to avoid additional costs for companies and SMEs.

- Combine economic input-output analysis with process-based analysis to achieve complete environmental performance of products and organizations throughout their entire supply chain.

Figure 21. The Environmental Footprint's Strengths-Weaknesses-Opportunities-Threats (SWOT) analysis and recommendations. LCA: Life Cycle Assessment; EF: Environmental Footprint; OEFCR: Organization Environmental Footprint Category Rule; PEFCR: Product Environment. 


\subsection{Strengths}

The European Commission's "Roadmap to a Resource Efficient Europe" proposed the target of achieving a more efficient use of natural resources by 2020. The global environmental sustainability was set as one of the main overarching goals of the European Union. Several footprints have been presented over the years as indicators to evaluate certain environmental impacts. The Carbon Footprint served as a useful tool to assess carbon emissions of cities, industrial sectors and nations (Brizga et al., 2015; Miehe et al., 2016; Tian et al., 2016). In a similar way the Water Footprint and the Ecological Footprint emerged as indicators of certain impacts (Ali et al., 2017)(Chen et al., 2017; McDonald and Patterson, 2004). However, the European Commission aiming at establishing the Single Market for Green Products, proposed the new indicator of the EF. It differs from the existing Carbon Footprint and Water Footprint in the fact that the EF provides a multi-criteria measure of the environmental performance of a product or good. This indicator combines fifteen impact categories overcoming the restrictive environmental assessment of other indicators which only consider a single impact category (Alvarez et al., 2016). Including several environmental categories enables a much more comprehensive environmental perspective and increases the effectiveness of the sustainability assessment (Weidema et al., 2008).

The EF has also been presented as a quantifiable indicator. The impacts are measured in quantitative units, thus facilitating its implementation for environmental strategies and policies. The methodology is based on LCA, which evaluates the environmental effects of a product, process or activity throughout its life cycle or lifetime (Wolf et al., 2012). LCA is a recognized tool to carry out environmental assessments (Wu and Ma, 2018), which makes EF a robust and science-based approach (Vieira, 2018c). 
Input-Output Analysis for the quantification of the Environmental Footprint. Case studies in Spain

Traditional LCA has been used to identify hotspots. However, the identification of the most relevant processes and activities contributing to the total environmental impact has had great dependency on the LCA practitioner and the choices carried out. What the EF initiative aims to establish is a harmonized threshold identifying environmental tradeoffs and life cycle stages, processes and impact categories considered as the most relevant. Following this path, business will be able focus their efforts in improving those hotspots. In the EF, four types of hotspots are considered, differentiating between those relevant for external communication, for decision-making, for data quality requirements and for internal decision-making at the company level (Figure 22) (Vieira, 2018d).

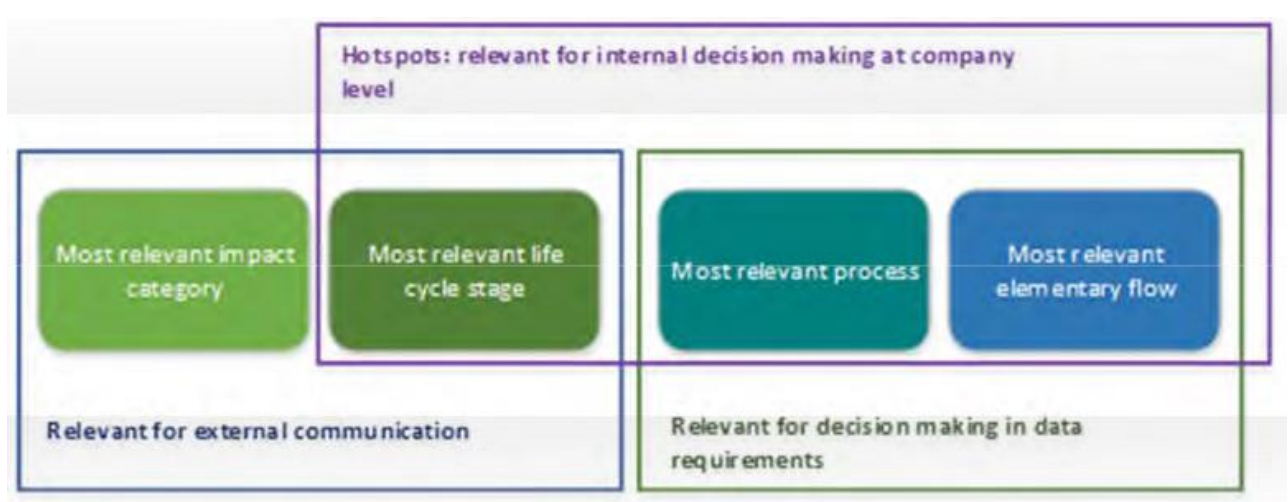

Figure 22. Hotspot analysis in the Environmental Footprint initiative (Vieira, 2018d).

\subsection{Weaknesses}

The EF, which was conceived in the context of United Nations' SDG and advocates for a more sustainable consumption and production, has the shortcoming of not considering the social and economic dimensions. To date, the European Commission has focused the effort towards the creation of the EF as a standard related to the environmental dimension, lacking perspective on the other two dimensions which have been established as key goals worldwide (Axon and James, 2018). 
Also the inclusiveness criterion of the selected impact categories of the EF has been criticized because relevant human impacts on the environment are still not fully considered. The environmental performance of products and organizations obtained by means of the EF will be evaluated partially, neglecting impacts related to loss of biodiversity, noise, and animal welfare, among others (European Commission, 2017d).

Another weakness of the EF is the insufficient maturity of the methodology leading to practicability issues. Some of these issues are the need to provide a detailed definition of the studied product or organization. Parameters to measure the performance aspects of products and companies are essential when defining the functional unit. The use of secondary data could lead to biased results and discharge comparison purposes. In relation to the impact assessment, the granularity of the impact categories is inconsistent having, for example, a unique impact category for land use, and three different categories for eutrophication.

The application of methods which are not ready to be widely applied yet presents another challenge of this methodology. On the one hand, carrying out a LCA based only on the process-based method requires a very exhaustive work resulting in high costs and time. On the other hand, carrying out a LCA based on the EEMRIO method could generate mistrust due to the lack of experience applying this method, as traditionally, LCAs applied the process-based method.

Finally, the EF was proposed as a tool capable of identifying the most relevant processes and activities contributing to the total environmental impact. However, in order to carry out this evaluation, results need to be normalized and weighted. At the moment, normalization is one of the main challenges due to the lack of data for calculating the normalization factors. Normalization factors inventories are typically incomplete as they are based only on measurable substances, which can be detected with current methods. 
Input-Output Analysis for the quantification of the Environmental Footprint. Case studies in Spain

Furthermore, the weighting step can be seen imprecise and ambiguous due to its subjective nature. Initially, categories contributing cumulatively to $80 \%$ of the total environmental impacts were considered. The idea of changing the criteria is being studied, for instance, including all impact categories which contribute more than $5 \%$ or including the categories contributing at least $90 \%$ to the overall impact (Lehmann et al., 2016).

\subsection{Opportunities}

Since the presentation of the Ecological Footprint, successive footprints have been emerging over the years, followed by the proliferation of different methods and approaches to calculate the mentioned footprints. In light of this growing concern among Member States and industries, the European Commission decided to implement a new approach that could be used in existing or new EU policies. The EF aims at providing a common basis for calculating and transmitting the environmental performance of products and organizations across the European countries (Galatola and Pant, 2014). Once a consistent and harmonized indicator is established, companies and stakeholders will be willing to track their environmental impacts and offer added value with their environmental image based on a reliable assessment (Huang et al., 2009; Matthews and Lave, 2003).

In relation to this point, the $\mathrm{EF}$ assessment offers the possibility for companies of gaining competitive advantage regarding the environmental aspects. The PEFCRs and OEFCRs can serve as guide for comparison and to establish a European benchmark. This means the environmental profile of the average European of a specific product and organization will be available so that companies can contrast their environmental performance. 
Currently, leading companies are starting to quantify their EF. This is the case of the Spanish electrical company Iberdrola, which is an international company producing and providing electricity to more than 100 million people (Iberdrola, 2018a). Having the goal of reducing its carbon emissions $30 \%$ by 2020 , this company has already obtained and identified its direct and indirect environmental impacts (Iberdrola, 2018b).

The ultimate goal that will be achieved by implementing the EF quantification is the promotion of an environmentally friendly market. At the moment, the global market for low carbon environmental goods and services is estimated at 4.2 trillion euros (European Commission, 2018a). Benefits derived from green growth and sustainability are twofold, on the one hand, green and organic products will be available in the market for consumers. The lack of availability of these products was identified as a barrier impeding sustainable consumption (Kaufmann et al., 2012). On the other hand, investors and companies will benefit from the implementation of innovative environmental measures, such as an efficient use of materials and energy along the supply chain which will achieve cost- savings (Weidema et al., 2008).

\subsection{Threats}

The target of developing the EF was to create a harmonized methodology for the calculation of the environmental footprint of products and organizations taking into account existing methods and initiatives (European Commission, 2012). However, significant differences between the already implemented standards and the new EF were highlighted (Finkbeiner, 2014). The main contradiction between EF and ISO 14040/44 relies on the fact that ISO standards state that LCA shall not provide comparative assertions due to the subjective nature of weighting and normalization, while EF allows comparison without needing additional information (Lehmann et al., 2016). In this regard, 
the EF could be seen as a new methodology which, instead of harmonizing, adds to the existing standards contributing to proliferation and discordance of environmental guidelines.

In line with the above-mentioned, the immaturity of the methodology could lead to unfair comparison between products and organizations and risks misleading and confusing consumers (FoodDrinkEurope, 2016). The introduction of a new indicator with new terminology could fail to communicate the environmental performance of products and organizations generating mistrust among consumers (Finkbeiner, 2014). In addition, it has not been addressed the issue of how the new PEF and OEF will interfere with the existing product labels and organizational reporting schemes (European Commission, 2016a).

Data quality was identified as a key issue from the starting point. In this sense, for the assessment of the EF, specific data quality requirements were set. However, during the pilot phase it was seen the quality of the data as a major constraint (Lehmann et al., 2016). An increasing concern has also arisen related to the definition of the EF boundaries. EF methodology does not allow cut-offs, thus, business and small and medium-sized enterprises could incur in high costs when carrying out this assessment making this approach inviable (Finkbeiner, 2014).

\subsection{Recommendations}

From the SWOT analysis, a series of recommendations can be highlighted to ameliorate the weaknesses and threats presented by the EF and enhance the strengths and opportunities for its implementation (Figure 21).

The consideration of the EF as a stand-alone tool provides a limited perspective focused only on the environmental dimension. By including socio-economic aspects 
through the application of social life cycle assessment (S-LCA) a more comprehensive sustainability assessment of impacts, benefits, and related trade-offs of products and organizations could be achieved (Sala et al., 2015). There have been approaches studying the inclusion of social aspects in companies as well as products along their life span (Tsalis et al., 2017).

One of the main flaws of the EF methodology was not considering some of the environmental impacts. To overcome this limitation, the environmental results obtained for the specified impact categories could be complemented using other approaches. For instance, the United Nations Environment Programme /Society of Environmental Toxicology and Chemistry proposed the development of LCA models and indicators for land use impacts on biodiversity. It was concluded that species richness was a good starting point for assessing biodiversity loss (Teixeira et al., 2016). The EF could definitely benefit from the inclusion of biodiversity indicators and provide more robust decisions.

In order to avoid distortion of the normalized and weighted results caused by the number of impact categories used, it is recommended to cluster those impacts which are represented by several impact categories. Currently, the impact categories eutrophication, acidification, resources and toxicity are represented by more than one category (Wolf et al., 2012) and the idea would be to group them to provide consistency and fair weighting. Another aspect is the established methods for EF calculation. The published methods by the Joint Research Center included 14 impact assessment methods on midpoint level and three methods on endpoint level, each of them stating their maturity level. Only two methods, i.e. the Intergovernmental Panel on Climate Change method for climate change and World Meteorological Organization method for method for ozone depletion, fulfill all the necessary requirements. Whereas, the rest of the methods are characterized as 
Input-Output Analysis for the quantification of the Environmental Footprint. Case studies in Spain

"only be applied with caution" and "recommended, some improvements needed" (JRC European commission, 2011). These latter methods should not be used as they have not been sufficiently tested in real-world applications. Instead other available and robust methods, such as Pfister et al. (2009) and Berger et al. (2014) for water depletion and Schneider (2014) for resource depletion.

One of the main strengths of this methodology is its capacity of providing comparison and benchmarking. In order to do so, PEFCRs and OEFCRs have been developed and tested in the pilot phase to provide a reference product or organization. In determining PEFCRs, one of the main challenges encountered was defining the product category, which in some cases included a wide variety of products and in others a narrow selection of products. To date, the granularity of scope of several of the final PEFCRs remains as an unsolved issue. For that reason, further research is suggested during the transitional phase, which follows the pilot phase already finalized (European Commission, 2018b).

Attention has to be paid to the fact that the EF methodology is in conflict with other recognized standards, such as ISO 14040/44. ISO standards establish normalization and weighting as voluntary steps in the LCA, while EF claims comparative assertions based on normalized and weighted results. Normalization and weighting steps are, at the moment, regarded as ambitious goals not yet achievable (Lehmann et al., 2016). Therefore, it is recommended not to carry these steps for now. In the future, normalization and weighting could be contemplated by decision-makers from a political point of view. Additionally, it has to be studied a suitable approach of harmonizing this new methodology with the existing product and organizational labels without undermining their significance, as some of them have been implemented for years (The Blue Angel, 2018; The Nordic Council, 2014). 
Another recommendation could be to simplify the terminology applied in this methodology. The introduction of new terms, such as unit of analysis instead of functional unit or resource use and emission profile instead of LCI (Daddi et al., 2015), could be counterproductive when transmitting the information and reduce its credibility among consumers. It has to be noted that a good and simpler proposal could have been to use already existing terminology and it would not have devaluated this new approach.

The requirement of regionalized inventory data to conduct the EF assessment has been found to be high resource-demanding for companies (Finkbeiner, 2014). In order to avoid the extra costs for businesses and small and medium-sized enterprises, the European Commission would need to destiny resources to obtain specific data for the relevant processes. Taking into consideration time, cost and resources, datasets with the maximum level of detail should be generated to provide consistency in the results.

Finally, IO analysis was presented as a robust method for assessing the environmental impacts along the supply chain (Zafrilla et al., 2014). The development of MRIO tables, such as EXIOBASE2, could be combined with process-based data to achieve the complete cradle-to-grave assessment. It also complies with the requirement of not allowing cut-offs, as with the IO analysis the upstream and downstream indirect impacts are obtained (Suh and Huppes, 2005).

\section{Limitations and benefits of the environmentally- extended multi-regional input-output analysis}

The application of the environmentally-extended input-output analysis presents several advantages as previously mentioned in the input-output method (Figure 23). The quantity and detail of data required is less than the demanded by the process-based approach, thus needing less resources and time to conduct the studies. Free data is already 
available for the public, such as different MRIO tables and environmental accounts. Furthermore, a main advantage is the inclusion of the supply chain environmental impacts, avoiding the truncation effect derived from stablishing system boundaries in the process-based method.

However, the EEMRIO analysis presents some limitations that need to be acknowledged (Figure 23). When conducting a study, the EEMRIO analysis considers that the quantity of imported goods is negligible and they are not considered in the study. In addition, it is assumed that the exporting countries produce their goods and services using the same technology and same economic structure as the country where the study is being performed, so that the goods and services can be considered as domestic (Suh, 2004). When interpreting the environmental results this fact has to be considered, as in many cases the imported goods and services come from developing countries with different technology and economic structure than developed regions.

Another point to highlight is the sector aggregation. EEMRIO is based on MRIO tables which show different products and services aggregated in activity sectors. This aggregation provides less resolution and a lower level of detail than the process-based method. Additionally, the EEMRIO analysis assumes that the products and services allocated to an activity sector are homogeneous (Kitzes, 2013). Thus, different products and services can result in the same environmental effects. Another aspect to consider is the units of the inputs. Data is often presented in physical units. In order to correlate physical units with monetary units, the production costs are used. However, this means the analysis may be vulnerable to price heterogeneity and fluctuations.

In relation to the environmental accounts, the EEMRIO requires specific information for each region or study area. Nevertheless, few environmental accounts have been developed at national level, reducing the reliability of the environmental impacts. 
Moreover, only in some countries the environmental accounts are related to the MRIO tables (Suh and Huppes, 2005). In the same way as occurs with the technical coefficients in the input-output method, the environmental vectors are also fixed, presenting a linear relationship between the changes in final demand and the environmental impacts.

As mentioned for the input-output method, the availability of the MRIO tables are often free. However, the compilation of MRIO tables is time-consuming and so a main shortcoming is the time availability of these tables (Wiedmann et al., 2011). As a consequence, technology changes in production, technology advances and the use of better available technologies for the environment are not shown in the results obtained from an EEMRIO analysis. Emerging technologies are difficult to evaluate through this approach because they are not included in the national accounts and not considered in the environmental accounts. In order to assess new technologies, the best option would be to apply the EEMRIO analysis once the technology has achieved a certain level of maturity and the production costs have stabilized. Otherwise, the results would be biased by the fact that, initially, the production costs using that technology would be very high, thus, generating high environmental impacts. 
Input-Output Analysis for the quantification of the Environmental Footprint. Case studies in Spain

\section{EEMRIO Strengths}

- Real and reliable data. Accurate and thoroughly checked tables based on a system of national accounts.

- Publicly available input-output tables.

- Less level of detail and quantity of data required. Saves time and resources.

- Ability to track the impacts of international production and supply chains. Covers all intersectoral connections including direct and indirect impacts caused by upstream production.

- Avoids double counting by allocating environmental impacts between sectors.

\section{EEMRIO Weaknesses}

- Assumption of same technology and economic structure among countries.

- Low sector resolution leading to aggregation and vulnerability to price fluctuations.

- Homogeneity of products and services, assuming that each sector in the economy produces a single, homogeneous product or service.

- Linear model assuming a constant, fixed technological coefficients, as well as, fixed environmental vectors.

- Input-output tables may be published with large time lags, so presenting the constraint of time availability of input-output data.

Figure 23.The environmental-extended multi-regional input-output (EEMRIO) analysis strengths and weaknesses. 


\section{CONCLUSIONS}



The environmental degradation is a reality that needs to be addressed without delay. Several policies and measures have been promoted to face this challenge, such as the SDG. Following this path new ways to measure human impacts on nature are being developed. The quantification of the environmental impacts through a reliable and comprehensive tool can favor a more sustainable consumption and production.

This study aimed at studying the EF applying the EEMRIO analysis as a useful indicator to evaluate the environmental performance of organizations and production systems. By investigating a series of case studies, the applicability of this indicator and its calculation is presented.

The following conclusions were derived from this $\mathrm{PhD}$ thesis:

1. The EF is a multi-criteria indicator capable of capturing the entire picture concerning the environmental impacts. The results obtained in the case studies show that the fourteen impact categories provide a complete perspective of the environmental pressures generated.

2. The EEMRIO analysis was found to be a reliable tool to calculate the EF, without the need to establish subjective system boundaries and cut-off criteria. System boundaries are established objectively, allowing homogeneous bases for comparison.

3. The application of the EEMRIO analysis allows the assessment of the environmental impacts across different regions, while single-region input-output analysis focuses only on a specific country.

4. In the case studies presented, it was demonstrated that direct and indirect impacts can be obtained through EEMRIO analysis by applying the structural path analysis. This technic allows the impact assessment along the entire supply chain identifying direct and indirect environmental impacts. 
5. An advantage presented by the EEMRIO analysis is the fact that it can be updated. Up-to-date MRIO tables can be used in order to increase the accuracy of the results and assess time-series analysis.

6. The EF obtained with the EEMRIO analysis allows the detection of the source of the environmental impacts. It was proved that this aspect allows researchers and governments to assess the tracing of linkages among sectors contributing to the impacts and to numerically evaluate direct, indirect and induced effects.

\subsection{Further Investigation}

In relation to this investigation, further research can be focused on integrating social aspects, such as employment generation and labor hours. This assessment will provide a deeper insight to human's well-being and will address the new initiatives from the environmental and social point of view.

Regarding the application of the EEMRIO approach, it would be worth studying its application on products. Although there is an extent literature on the EEMRIO method (de la Rua and Lechon, 2016; Mongelli et al., 2010; Reutter et al., 2017), it is mainly based on sectorial and national level perspectives (Alcántara and Padilla, 2009; Benini et al., 2014; Matthews and Lave, 2003; Wood and Dey, 2009). The application of this method to products has been limited due to the data provided in the IOT. These tables provide commodity products that are aggregated in broad categories including a large number of products. In this sense, comparing heterogeneous products that differ significantly from the commodity product category or new products would lead to biased results (Joshi, 1999). However, the development of more precise MRIO tables, such as EXIOBASE, offers the possibility of analyzing the environmental impacts at the micro level of products. This database provides 200 commodity products, increasing the data 
detail, which combined with its environmental extensions, allows the assessment of environmental impacts of products.

In addition, the release of new MRIO databases and updated environmental accounts provides more accurate results. A future study can be conducted applying this method with EXIOBASE 3 database (Stadler et al., 2018). It has just been developed and provides time series tables from 1995 to 2011. The results from the application of this database to new case studies will provide more reliable results due to the smaller time lag.

Finally, comparison studies could also provide valuable information regarding the robustness of the EEMRIO method. During the EF pilot phase, several LCAs were performed following the process-based method (Famiglietti et al., 2018; SoodeSchimonsky et al., 2017). Comparing the results obtained in these studies with the findings obtained applying the EEMRIO method could provide the level of error and interesting insights of each method. 



\section{REFERENCES}



Adams, W.M., 2006. The Future of Sustainability Re-thinking Environment and Development in the Twenty-first Century.

Ahmed, M.T., 2018. Land use change, climate change and biodiversity [WWW Document]. URL http://grimstad.uia.no/puls/climatechange2/nni04/08nni04.htm

Albort-Morant, G., Henseler, J., Leal-Millán, A., Cepeda-Carrión, G., 2017. Mapping the Field: A Bibliometric Analysis of Green Innovation. Sustainability 9, 1011. doi:10.3390/su9061011

Alcántara, V., Padilla, E., 2009. Input-output subsystems and pollution: An application to the service sector and $\mathrm{CO} 2$ emissions in Spain. Ecol. Econ. 68, 905-914. doi:10.1016/j.ecolecon.2008.07.010

Ali, Y., Pretaroli, R., Socci, C., Severini, F., 2018. Carbon and water footprint accounts of Italy: A Multi-Region Input-Output approach. Renew. Sustain. Energy Rev. 81, 1813-1824. doi:10.1016/j.rser.2017.05.277

Ali, Y., Pretaroli, R., Socci, C., Severini, F., 2017. Carbon and water footprint accounts of Italy: A Multi-Region Input-Output approach. Renew. Sustain. Energy Rev. 112. doi:10.1016/j.rser.2017.05.277

Alvarez, S., Carballo-Penela, A., Mateo-Mantecón, I., Rubio, A., 2016. StrengthsWeaknesses-Opportunities-Threats analysis of carbon footprint indicator and derived recommendations. J. Clean. Prod. 121, 238-247. doi:10.1016/j.jclepro.2016.02.028

Alvarez, S., Rubio, A., 2015. Compound method based on financial accounts versus process-based analysis in product carbon footprint: A comparison using wood pallets. Ecol. Indic. 49, 88-94. doi:10.1016/j.ecolind.2014.10.005

Andersen, M.S., 2007. An introductory note on the environmental economics of the circular economy. Sustain. Sci. 2, 133-140. doi:10.1007/s11625-006-0013-6

Arora, K., Schlick, T., 2004. Impact Category. Toxicity Potential, LCANZ.

Arto, I., Andreoni, V., Rueda-Cantuche, J.M., 2016. Global use of water resources: A multiregional analysis of water use, water footprint and water trade balance. Water Resour. Econ. 15, 1-14. doi:10.1016/j.wre.2016.04.002

Axon, S., James, D., 2018. The UN Sustainable Development Goals: how can sustainable chemistry contribute? A view from the chemical industry. Curr. Opin. Green Sustain. Chem. doi:10.1016/j.cogsc.2018.04.010

Bach, V., Lehmann, A., Görmer, M., Finkbeiner, M., Bach, V., Lehmann, A., Görmer, M., Finkbeiner, M., 2018. Product Environmental Footprint (PEF) Pilot PhaseComparability over Flexibility? Sustainability 10, 2898. doi:10.3390/su10082898

Bascom, C.R., 2016. From Economic Growth To Sustainable Development [WWW Document]. URL https://sustainabilityx.co/economic-growth-to-sustainabledevelopment-5d441e9a595e (accessed 9.8.18).

Baxter, R., Hastings, N., Law, A., Glass, E.J.., 2008. Impact Category. Global Warming Potential, LCANZ.

Bellard, C., Bertelsmeier, C., Leadley, P., Thuiller, W., Courchamp, F., 2012. Impacts of climate change on the future of biodiversity. Ecol. Lett. 15, 365-377. 
Input-Output Analysis for the quantification of the Environmental Footprint. Case studies in Spain

doi:10.1111/j.1461-0248.2011.01736.x

Benedetti, I., Laureti, T., 2017. Exploring pro-environmental food purchasing behaviour: an empirical analysis of italian consumers. J. Clean. Prod. doi:10.1016/j.jclepro.2017.11.086

Benini, L., Mancini, L., Sala, S., Manfredi, S., Schau, E.M., Pant, R., 2014. Normalisation method and data for Environmental Footprints. doi:10.2788/16415

Berariu, R.T., Mihaela, M., 2011. Analysis of Sustainable Development Strategies Using SWOT.

Berger, M., van der Ent, R., Eisner, S., Bach, V., Finkbeiner, M., 2014. Water Accounting and Vulnerability Evaluation (WAVE): Considering Atmospheric Evaporation Recycling and the Risk of Freshwater Depletion in Water Footprinting. Environ. Sci. Technol. 48, 4521-4528. doi:10.1021/es404994t

Bergh, J.C.J.M. Van Den, Verbruggen, H., 1999. Spatial sustainability, trade and indicators : an evaluation of the ' ecological footprint' $29,61-72$.

Blanc, D. Le, 2015. Towards Integration at Last? The Sustainable Development Goals as a Network of Targets. Sustain. Dev. 23, 176-187. doi:https://doi.org/10.1002/sd.1582

British Standard Institute, 2011. PUBLICLY AVAILABLE SPECIFICATION PAS 2050: 2011 Specification for the assessment of the life cycle greenhouse gas emissions ofgoods and services.

Brizga, J., Feng, K., Hubacek, K., 2017. Household carbon footprints in the Baltic States: A global multi-regional input-output analysis from 1995 to 2011. Appl. Energy 189, 780-788. doi:10.1016/j.apenergy.2016.01.102

Brizga, J., Feng, K., Hubacek, K., 2015. Household carbon footprints in the Baltic States: A global multi-regional input-output analysis from 1995 to 2011. Appl. Energy. doi:10.1016/j.apenergy.2016.01.102

Brundtland, G., 1987. Report of the World Commision on Environement and Development: Our Common Future. Oxford Pap. Report of, 400. doi: $10.2307 / 2621529$

Cai, B., Liu, B., Zhang, B., 2019. Evolution of Chinese urban household's water footprint. J. Clean. Prod. 208, 1-10. doi:https://doi.org/10.1016/j.jclepro.2018.10.074

Cañas-Guerrero, I., Mazarrón, F.R., Pou-Merina, A., Calleja-Perucho, C., Díaz-Rubio, G., 2013. Bibliometric analysis of research activity in the "Agronomy" category from the Web of Science, 1997-2011. Eur. J. Agron. 50, 19-28. doi:10.1016/j.eja.2013.05.002

Carbon Footprint, 2018. CARBON FOOTPRINT [WWW Document]. URL https://www.carbonfootprint.com/ (accessed 7.8.18).

Carbon Trust, 2018. The Carbon Trust Standard [WWW Document]. URL https://www.carbontrust.com/home/ (accessed 7.8.18).

Castellani, V., Sala, S., 2012. Ecological Footprint and Life Cycle Assessment in the sustainability assessment of tourism activities. Ecol. Indic. 16, 135-147. doi:https://doi.org/10.1016/j.ecolind.2011.08.002 
Cazcarro, I., Hoekstra, A.Y., Sánchez Chóliz, J., 2014. The water footprint of tourism in Spain. Tour. Manag. 40, 90-101. doi:10.1016/j.tourman.2013.05.010

Chapagain, A.K., Hoekstra, A.Y., Savenije, H.H.G., Gautam, R., 2005. The water footprint of cotton consumption: An assessment of the impact of worldwide consumption of cotton products on the water resources in the cotton producing countries 0. doi:10.1016/j.eco

Charles, L., 2003. The visual history of the Tableau Économique. Eur. J. Hist. Econ. Thought 10, 527-550. doi:10.1080/0967256032000137702

Chen, G., Hadjikakou, M., Wiedmann, T., Shi, L., 2018. Global warming impact of suburbanization: The case of Sydney. J. Clean. Prod. 172, 287-301. doi:10.1016/j.jclepro.2017.10.161

Chen, W., Wu, S., Lei, Y., Li, S., 2017. China's water footprint by province, and interprovincial transfer of virtual water. Ecol. Indic. 74, 321-333. doi:10.1016/j.ecolind.2016.11.037

Circular Ecology, 2018. Sustainability and sustainable development - What is sustainability and what is sustainable development? [WWW Document]. URL http://www.circularecology.com/sustainability-and-sustainabledevelopment.html\#.W8iT7Xv7Tcs (accessed 7.7.18).

Cucek, L., Kravanja, Z., 2012. A Review of Footprint analysis tools for monitoring impacts on sustainability 34. doi:10.1016/j.jclepro.2012.02.036

Daddi, T., Iraldo, F., Testa, F., 2015. Environmental Certification for Organisations and Products: Management approaches and operational tools.

Dalby, S., 2016. Contextual Changes in Earth History: From the Holocene to the Anthropocene - Implications for Sustainable Development and for Strategies of Sustainable Transition. Springer, Cham.

Dalgleish, T., Williams, J.M.G.., Golden, A.-M.J., Perkins, N., Barrett, L.F., Barnard, P.J., Au Yeung, C., Murphy, V., Elward, R., Tchanturia, K., Watkins, E., 2007. Impact Category. Land Use, LCANZ.

Danish Environmental Protection Agency, 2005. Photochemical ozone formation [WWW Document]. URL https://www2.mst.dk/udgiv/publications/2005/87-7614574-3/html/kap06_eng.htm

De Gruyter, 2015. Coping with the anthropocene: How we became nature [WWW Document]. https://www.sciencedaily.com/releases/2015/03/150317093001.htm

de la Rua, C., Lechon, Y., 2016. An integrated Multi-Regional Input-Output (MRIO) Analysis of miscanthus biomass production in France: Socio-economic and climate change consequences. Biomass and Bioenergy 94, 21-30. doi:10.1016/j.biombioe.2016.08.003

Deng, G., Ma, Y., Li, X., 2016. Regional water footprint evaluation and trend analysis of China-based on interregional input-output model. J. Clean. Prod. 112, 4674-4682. doi:10.1016/j.jclepro.2015.07.129

Denholm, P., Kulcinski, G.L., 2004. Life cycle energy requirements and greenhouse gas 
Input-Output Analysis for the quantification of the Environmental Footprint. Case studies in Spain

emissions from large scale energy storage systems. Energy Convers. Manag. 45, 2153-2172. doi:10.1016/j.enconman.2003.10.014

Dias, A.C., Lemos, D., Gabarrell, X., Arroja, L., 2014. Environmentally extended input e output analysis on a city scale e application to Aveiro ( Portugal ). J. Clean. Prod. 75, 118-129. doi:10.1016/j.jclepro.2014.04.012

Diaz-Sarachaga, J.M., Jato-Espino, D., Castro-Fresno, D., 2018. Is the Sustainable Development Goals (SDG) index an adequate framework to measure the progress of the 2030 Agenda? Sustain. Dev. doi:10.1002/sd.1735

Dirección general del agua (DGA), 2010. Estrategia nacional para la modernización sostenible de los regaddios $\mathrm{H} 2015$.

Druckman, A., Jackson, T., 2009. The carbon footprint of UK households 1990-2004 : a socio-economically disaggregated, quasi-multi-regional input-output model 1-26.

Du Pisani, J.A., 2006. Sustainable development - historical roots of the concept. Environ. Sci. 3, 83-96. doi:10.1080/15693430600688831

Duarte, R., Mainar, A., Sánchez-Chóliz, J., 2012. Social groups and CO 2 emissions in Spanish households. Energy Policy 44, 441-450. doi:10.1016/j.enpol.2012.02.020

EC Institute for Environmental and Sustainability, 2010. Analysis of Existing Environmental Footprint Methodologies for Products and Organizations : Recommendations, Rationale, and Alignment. Analysis.

Ecolabel, E.U., 2017. Discover the vast range of EU Ecolabelled products and services Five reasons to choose EU Ecolabel Find out how the EU Ecolabel works.

EEA, 2014. Trends and projections in Europe 2014, EEA Report 6/2014. doi:10.2800/93693

Ercin, A.E., Mekonnen, M., Hoekstra, A.Y., 2013. Sustainability of national consumption from a water resources perspective: The case study for France 88, 133-147. doi:10.1016/j.ecolecon.2013.01.015

European Centre for Ecotoxicology and Toxicology of Chemicals (ECETOC), 2016. EUROPEAN CENTRE FOR ECOTOXICOLOGY AND TOXICOLOGY OF CHEMICALS Freshwater ecotoxicity as an impact category in life cycle assessment.

European Comission, 2013. Living well, within the limits of our planet. General Union Environment Action Programme to 2020. Off. J. Eur. Union 354, 171-200. doi: $10.2779 / 57220$

European Commision, 2014. A policy framework for climate and energy in the period from 2020 to 2030. Https://Ec.Europa.Eu/Energy/En/Topics/Energy-Strategy/2030Energy-Strategy Brussels. doi:10.1007/s13398-014-0173-7.2

European commission, 2013. Particulate matter/Respiratory inorganics [LCA] [WWW Document]. URL https://biobs.jrc.ec.europa.eu/glossary/p/particulatematterrespiratory-inorganics (accessed 10.10.18).

European commission, 2012. Policy background [WWW Document]. URL http://ec.europa.eu/environment/eussd/smgp/policy_footprint.htm (accessed 12.10.18). 
European Commission, 2018a. Facts and Figures [WWW Document]. URL http://ec.europa.eu/environment/eussd/smgp/facts_and_figures_en.htm (accessed 7.11.18).

European Commission, 2018b. The Environmental Footprint transition phase [WWW Document]. URL http://ec.europa.eu/environment/eussd/smgp/ef_transition.htm (accessed 10.10.18).

European Commission, 2018c. Environmental Footprint [WWW Document]. URL http://ec.europa.eu/environment/eussd/smgp/policy_footprint.htm (accessed 10.3.17).

European Commission, 2018d. Single Market for Green Products Initiative [WWW Document]. URL http://ec.europa.eu/environment/eussd/smgp/ (accessed 10.21.17).

European Commission, 2017a. Multilateral Environmental Agreements [WWW Document]. http://ec.europa.eu/environment/international_issues/agreements_en.htm (accessed 9.9.18).

European Commission, 2017b. Single Market for Green Products Initiative [WWW Document]. URL http://ec.europa.eu/environment/eussd/smgp/index.htm (accessed 8.8.18).

European Commission, 2017c. Policy background [WWW Document]. URL $\mathrm{http}$ ://ec.europa.eu/environment/eussd/smgp/policy_footprint.htm (accessed 6.6.18).

European Commission, 2017d. Review report of the Environmental Footprint Pilot phase $1-48$.

European Commission, 2016a. Buying green! doi:10.2779/246106

European Commission, 2016b. What environmental impacts does PEF consider? [WWW Document]. URL http://ec.europa.eu/environment/eussd/smgp/communication/impact.htm

European Commission, 2015. The 2030 Agenda for Sustainable Development [WWW Document]. URL https://ec.europa.eu/europeaid/policies/european-developmentpolicy/2030-agenda-sustainable-development_en

European Commission, 2013. Organisation Environmental Footprint Guide. Eur. Comm. $\begin{array}{llll}\text { Res. } & \text { Centre-Institute } & \text { Environ. } & \text { Sustain. }\end{array}$ doi:doi:10.3000/19770677.L_2013.124.eng

European Commission, 2012. Product Environmental Footprint ( PEF ) Guide.

European Commission, 2011. Roadmap to a Resource Efficient Europe.

European Commission, 2009. The Montreal Protocol • 1-19.

European Environment Agency, 2013a. Air quality in Europe, EEA Report No 4/2012. doi:doi:10.2800/413142

European Environment Agency, 2013b. Environmental pressures from European consumption and production - A study in integrated environmental and economic analysis, EEA Technical Report No. 2/2013. doi:10.2800/70634 
Input-Output Analysis for the quantification of the Environmental Footprint. Case

studies in Spain

European Environmental Agency, 2018. International Geosphere-Biosphere Programme (IGBP) [WWW Document]. URL https://www.eea.europa.eu/themes/climate/links/physical-science-onclimate/Link315 (accessed 4.7.18).

Eurostat, 2018. Renewable energy statistics [WWW Document]. URL http://ec.europa.eu/eurostat/statisticsexplained/index.php/Renewable_energy_statistics (accessed 11.14.17).

Eurostat, 2008. Eurostat Manual of Supply, Use and Input-Output Tables, Methodologies and working papers, Economy and finance. doi:http://ec.europa.eu/eurostat

Fairbridge, L.D.A.R.W., 2018. Holocene Epoch [WWW Document]. URL https://www.britannica.com/science/Holocene-Epoch

Famiglietti, J., Guerci, M., Proserpio, C., Ravaglia, P., Motta, M., 2018. Development and testing of the Product Environmental Footprint Milk Tool: a comprehensive LCA tool for Dairy products Science of the Total Environment Research Paper (in press). Sci. Total Environ. 648, 1614-1626. doi:10.1016/j.scitotenv.2018.08.142

Fan, J.-L., Wang, J.-D., Zhang, X., Kong, L.-S., Song, Q.-Y., 2019. Exploring the changes and driving forces of water footprints in China from 2002 to 2012: A perspective of final demand. Sci. Total Environ. 650, 1101-1111. doi:https://doi.org/10.1016/j.scitotenv.2018.08.426

Fang, K., 2015. Footprint family: Concept, classification, theoretical framework and integrated pattern, Shengtai Xuebao/ Acta Ecologica Sinica. doi:10.5846/stxb201305211128

Ferng, J., 2002. Toward a scenario analysis framework for energy footprints 40, 53-69.

Finkbeiner, M., 2014. Product environmental footprint - Breakthrough or breakdown for policy implementation of life cycle assessment? Int. J. Life Cycle Assess. 19, 266271. doi:10.1007/s11367-013-0678-x

FoodDrinkEurope, 2016. Product Environmental Reports: Experience and recommendations of the food and drink sector 20 .

Fox, R., 2010. Impact Category. Eutrophication Potential.

Galatola, M., Pant, R., 2014. Reply to the editorial "product environmental footprint breakthrough or breakdown for policy implementation of life cycle assessment?" Written by Prof. Finkbeiner (Int J Life Cycle Assess 19(2):266-271). Int. J. Life Cycle Assess. 19, 1356-1360. doi:10.1007/s11367-014-0740-3

Garfield, L., 2018. 13 cities that are starting to ban cars. Bus. Insid.

Global Footprint Network, 2017. Making the Sustainable Development Goals consistent with sustainability [WWW Document]. URL https://www.footprintnetwork.org/2017/09/01/making-sustainable-developmentgoals-consistent-sustainability/ (accessed 7.8.18).

Global Footprint Network, 2003. Ecological Footprint [WWW Document]. URL https://www.footprintnetwork.org/our-work/ecological-footprint/ (accessed 3.6.18).

Goniadis, G., 2015. Introduction To Sustainable Development. 
Grunewald, P., Diakonova, M., 2018. The electricity footprint of household activities implications for demand models. Energy Build. 174, 635-641. doi:https://doi.org/10.1016/j.enbuild.2018.06.034

Guinee, J., Heijungs, R., Huppes, G., Zamagni, A., Masoni, P., Buonamici, R., Ekvall, T., Rydberg, T., 2011. Life Cycle Assessment: Past, Present, and Future 45, 90-96.

Hoekstra, A., 2002. Virtual Water Trade: Proceedings of the International Expert Meeting on Virtual Water Trade.

Hoekstra, A.Y., Hung, P.Q., 2002. A quantification of virtual water flows between nations in relation to international crop trade. Water Res. 49, 203-9.

Hoekstra, A.Y., Mekonnen, M.M., 2012. The water footprint of humanity 109. doi:10.1073/pnas.1109936109

Howarth, R.B., 2012. Sustainability, WellBeing, and Economic Growth 32-39.

Huang, Y.A., Lenzen, M., Weber, C.L., Murray, J., Matthews, H.S., 2009. The role of input-output analysis for the screening of corporate carbon footprints. Econ. Syst. Res. 21, 217-242. doi:10.1080/09535310903541348

Iberdrola, 2018a. Iberdrola, la energética del futuro (Iberdrola, the energetic company of the future) [WWW Document]. URL https://www.iberdrola.com/conocenos/energetica-del-futuro (accessed 9.12.18).

Iberdrola, 2018b. HUELLA AMBIENTAL CORPORATIVA (HAC) (Corporate Environmental Footprint) [WWW Document]. URL https://www.iberdrola.com/teinteresa/iberdrola-te-cuenta/huella-ambiental-corporativa (accessed 9.12.18).

Incisa, 2014. Obras de reparación, adecuación e instalación de elementos de auscultación en la presa de los peñascales. Torrelodones. Madrid (Repair, adequacy and installation of auscultation elements in the dam of los peñascales. Torrelodones. Madrid).

INE, 2018. Encuesta de presupuestos familiares [WWW Document]. URL http://www.ine.es/dyngs/INEbase/es/operacion.htm?c=Estadistica_C\&cid=125473 6176806\&menu=resultados\&idp=1254735976608 (accessed 10.11.17).

INE, 2013. Encuesta de Presupuestos Familiares 2013, 12-13.

IPCC, 2007a. IPCC Fourth Assessment Report: Climate Change 2007 [WWW Document].

https://www.ipcc.ch/publications_and_data/ar4/wg1/en/spmsspm-human-and.html (accessed 7.7.18).

IPCC, 2007b. IPCC Climate Change Fourth Assessment Report: Climate Change 2007 [WWW Document]. URL http://www.ipcc.ch/ipccreports/assessments-reports.htm (accessed 6.19.18).

ISO (International Organization for Standardization), 2006. ISO 14040 [WWW Document]. URL https://www.iso.org/standard/37456.html

ISO 14040, 2006. Environmental management - Life cycle assessment - Principles and framework [WWW Document]. URL https://www.iso.org/standard/37456.html (accessed 12.10.18). 
Input-Output Analysis for the quantification of the Environmental Footprint. Case studies in Spain

ISO 14044, 2006. Environmental management - Life cycle assessment - Requirements and guidelines [WWW Document]. URL https://www.iso.org/standard/38498.html (accessed 10.12.18).

Ivanova, D., Stadler, K., Steen-Olsen, K., Wood, R., Vita, G., Tukker, A., Hertwich, E.G., 2016. Environmental Impact Assessment of Household Consumption. J. Ind. Ecol. 20, 526-536. doi:10.1111/jiec.12371

Ivanova, D., Vita, G., Steen-Olsen, K., Stadler, K., Melo, P.C., Wood, R., Hertwich, E.G., 2017. Mapping the carbon footprint of EU regions. Environ. Res. Lett. 12. doi:10.1088/1748-9326/aa6da9

Ives, C.D., Giusti, M., Fischer, J., Abson, D.J., Klaniecki, K., Dorninger, C., Laudan, J., Barthel, S., Abernethy, P., Martín-López, B., Raymond, C.M., Kendal, D., von Wehrden, H., 2017. Human-nature connection: a multidisciplinary review. Curr. Opin. Environ. Sustain. 26-27, 106-113. doi:10.1016/j.cosust.2017.05.005

Jin, R., Gao, S., Cheshmehzangi, A., Aboagye-Nimo, E., 2018. A Holistic Review of offsite Construction Literature Published between 2008 and 2018. J. Clean. Prod. 202, 1202-1219. doi:10.1016/j.jclepro.2018.08.195

Jin, R., Yuan, H., Chen, Q., 2019. Science mapping approach to assisting the review of construction and demolition waste management research published between 2009 and 2018. Resour. Conserv. Recycl. 140, 175-188. doi:10.1016/j.resconrec.2018.09.029

Joshi, S., 1999. Product Environmental Life-Cycle Assessment Using Input-Output Techniques. J. Ind. Ecol. 3, 95-120. doi:10.1162/108819899569449

JRC European commission, 2011. ILCD Handbook: Recommendations for Life Cycle Impact Assessment in the European context, Vasa. doi:10.278/33030

Kaufmann, H.R., Panni, M.F.A.K., Orphanidou, Y., 2012. FACTORS AFFECTING CONSUMERS' GREEN PURCHASING BEHAVIOR: AN INTEGRATED CONCEPTUAL FRAMEWORK. Amfiteatru Econ. J. 14, 50-69.

Kerkhof, A., Terlouw, W., Vieira, M., Alexandre, C., Bagard, R., 2017. Evaluation report: Technical evaluation of the EU EF pilot phase 27.

Kerkhof, A.C., Nonhebel, S., Moll, H.C., 2009. Relating the environmental impact of consumption to household expenditures: An input-output analysis. Ecol. Econ. 68, 1160-1170. doi:10.1016/j.ecolecon.2008.08.004

Kitzes, J., 2013. An Introduction to Environmentally-Extended Input-Output Analysis 489-503. doi:10.3390/resources 2040489

Klemeš, J.J., Varbanov, P.S., Lam, H.L., Yusup, S., 2016. Energy, Water and Environmental Footprint Interactions: Implications for the Major Economy Sectors of Europe, South East Asia and Worldwide. Procedia Eng. 148, 1199-1205. doi:https://doi.org/10.1016/j.proeng.2016.06.630

Kolbert, E., 2011. Enter the Anthropocene - Age of Man. Natl. Geogr. Mag. 219, 60-77.

Konur, O., 2012. The Evaluation of the Global Research on the Education: A Scientometric Approach. Procedia - Soc. Behav. Sci. 47, 1363-1367. doi:10.1016/j.sbspro.2012.06.827 
Kovacic Lukman, R., Glavic, P., Carpenter, A., Virtic, P., 2016. Sustainable consumption and production-Research, experience, and development- The Europe we want. J. Clean. Prod. 138, 139-147. doi:10.1016/j.jclepro.2016.08.049

Laakso, S., Lettenmeier, M., 2016. Household-level transition methodology towards sustainable material footprints. J. Clean. Prod. 132, 184-191. doi:https://doi.org/10.1016/j.jclepro.2015.03.009

Lave, L., Hendrickson, C., Horvath, A., 2002. Economic input-output models for environment life-cycle assessment. Environ. Sci. Technol 32, 184-191.

LCA, I., 2018. LCA Impact [WWW Document]. URL http://lcimpact.eu/downloads/documents/Chapter4_Ionizingradiation.pdfhttps://www.ncbi.nlm.nih.gov/books/NBK218707/ (accessed 8.6.18).

LCANZ, 2018. Impact Category. Acidification Potential.

Ledgard, S.F., Wei, S., Wang, X., Falconer, S., Zhang, N., Zhang, X., Ma, L., 2019. Nitrogen and carbon footprints of dairy farm systems in China and New Zealand, as influenced by productivity, feed sources and mitigations. Agric. Water Manag. 213, 155-163. doi:10.1016/j.agwat.2018.10.009

Lehmann, A., Bach, V., Finkbeiner, M., 2016. EU product environmental footprint-midterm review of the pilot phase. Sustainability 8, 1-13. doi:10.3390/su8010092

Lenzen, M., 2001. Errors in Conventional and Input-Output - based Life-Cycle Inventories. J. Ind. Ecol. 4, 127-148. doi:10.1162/10881980052541981

Lenzen, M., Pade, L.-L., Munksgaard, J., 2004. CO2 Multipliers in Multi-region InputOutput Models. Econ. Syst. Res. 16, 391-412. doi:10.1080/0953531042000304272

Leontief, W., 1970. Environmental Repercussions and the Economic Structure: An InputOutput Approach. Rev. Econ. Stat. 52, 262-271. doi:10.2307/1926294

Leontief, W., 1941. The Structure of American Economy, 1919-1929: An Empirical Application of Equilibrium Analysis. Cambridge, USA Harvard Univ. Press.

Leontief, W., 1936. Quantitative Input-Output Relations in the Economic System of the United States. Rev. Econ. Stat. 18, 105-125.

Life Cycle Initiative, 2007a. Life Cycle Management Programme [WWW Document]. URL https://www.lifecycleinitiative.org/activities/phase-i/life-cycle-managementprogramme/ (accessed 10.18.18).

Life Cycle Initiative, 2007b. Life Cycle Inventory Programme [WWW Document]. URL https://www.lifecycleinitiative.org/activities/phase-i/life-cycle-inventoryprogramme/ (accessed 4.2.18).

Life Cycle Initiative, 2007c. Life Cycle Impact Assessment Programme [WWW Document]. URL https://www.lifecycleinitiative.org/activities/phase-i/life-cycleimpact-assessment-programme/ (accessed 4.3.18).

Ling-Chin, J., Heidrich, O., Roskilly, A.P., 2016. Life cycle assessment (LCA) - From analysing methodology development to introducing an LCA framework for marine photovoltaic (PV) systems. Renew. Sustain. Energy Rev. 59, 352-378. doi:10.1016/j.rser.2015.12.058 
Liu, H.T., Guo, J.E., Qian, D., Xi, Y.M., 2009. Comprehensive evaluation of household indirect energy consumption and impacts of alternative energy policies in China by input-output analysis. Energy Policy 37, 3194-3204. doi:10.1016/j.enpol.2009.04.016

Live Science, 2013. Holocene Epoch: The Age of Man [WWW Document]. URL https://www.livescience.com/28219-holocene-epoch.html (accessed 10.10.18).

Lizasoain, A., Tort, L.F., Garcia, M., Gomez, M.M., Leite, J.P., Miagostovich, M.P., Cristina, J., Colina, R., Victoria, M., 2015. Impact Category. Ozone Depletion Potential, LCANZ.

Long, Y., Dong, L., Yoshida, Y., Li, Z., 2018a. Evaluation of energy-related household carbon footprints in metropolitan areas of Japan. Ecol. Modell. 377, 16-25. doi:https://doi.org/10.1016/j.ecolmodel.2018.03.008

Long, Y., Yoshida, Y., Dong, L., 2018b. Exploring the indirect household carbon emissions by source: Analysis on 49 Japanese cities. J. Clean. Prod. 167, 571-581. doi:10.1016/j.jclepro.2017.08.159

López, L.A., Arce, G., Morenate, M., Zafrilla, J.E., 2017. How does income redistribution affect households' material footprint? J. Clean. Prod. 153, 515-527. doi:10.1016/j.jclepro.2017.01.142

Lozano, R., 2008. Envisioning sustainability three-dimensionally. J. Clean. Prod. 16, 1838-1846. doi:10.1016/j.jclepro.2008.02.008

Majeau-Bettez, G., Strømman, A.H., Hertwich, E.G., 2011. Evaluation of Process- and Input-Output-based Life Cycle Inventory Data with Regard to Truncation and Aggregation Issues. Environ. Sci. Technol. 45, 10170-10177. doi:10.1021/es201308x

Markaki, M., Belegri-Roboli, A., Sarafidis, Mirasgedis, S., 2017. The carbon footprint of Greek households (1995-2012). Energy Policy 100, 206-215. doi:10.1016/j.enpol.2016.10.031

Martinez, S., del Mar Delgado, M., Marin, R.M., Alvarez, S., 2018. The environmental footprint of an organic peri-urban orchard network. Sci. Total Environ. 636, 569579. doi:10.1016/j.scitotenv.2018.04.340

Matthews, H.S., Lave, L.B., 2003. Using input-output analysis for corporate benchmarking. Benchmarking An Int. J. 10, 153-168. doi:10.1108/14635770310469671

McDonald, G.W., Patterson, M.G., 2004. Ecological Footprints and interdependencies of New Zealand regions. Ecol. Econ. 50, 49-67. doi:10.1016/j.ecolecon.2004.02.008

Meadows, D.H., Meadows, D. 1., Randers, J., III, W.W.B., 2018. The Limits to Growth : A Report to The Club of Rome ( 1972 ) 1-9.

Mekonnen, M.M., 2015. Environmental Science heat: a global assessment $\dagger$. doi:10.1039/c5ew00026b

Mi, Z., Guan, D., Liu, Z., Liu, J., Viguié, V., Fromer, N., Wang, Y., 2018. Cities: the core of climate change mitigation. J. Clean. Prod. 207, 582-589. doi:10.1016/j.jclepro.2018.10.034 
Miehe, R., Scheumann, R., Jones, C.M., Kammen, D.M., Finkbeiner, M., 2016. Regional carbon footprints of households: a German case study. Environ. Dev. Sustain. 18, 577-591. doi:10.1007/s10668-015-9649-7

Milà i Canals, L., Bauer, C., Depestele, J., Dubreuil, A., Freiermuth, R., Gaillard, G., Michelsen, O., Müller-Wenk, R., Rydgren, B., 2007. Key Elements in a Framework for Land Use Impact Assessment Within LCA. Int. J. Life Cycle Assess. 12, 2-4. doi:https://doi.org/10.1065/lca2006.05.250

Miller, R.E., Blair, P.D., 2009. Input - Output Analysis Foundations and Extensions, 2nd Editio. ed. Cambridge University Press.

Miller, R.E., Blair, P.D., 1985. Input - Output Analysis.

Miller, V.B., Landis, A.E., Schaefer, L.A., 2011. A benchmark for life cycle air emissions and life cycle impact assessment of hydrokinetic energy extraction using life cycle assessment. Renew. Energy 36, 1040-1046. doi:10.1016/j.renene.2010.08.016

Mimura, N., 2013. Sea-level rise caused by climate change and its implications for society. Proc. Jpn. Acad. Ser. B. Phys. Biol. Sci. 89, 281-301. doi:10.2183/pjab.89.281

Ministerio de Fomento, 2009. Estrategia Española de movilidad sostenible. Portal.

Ministerio de Industria Energía y Turismo, 2015. Estrategia de Impulso del vehículo con energías alternativas ( VEA ) en España ( 2014-2020 ) 12.

Ministry for the Environment New Zealand, 2018. Impact Category Descriptions [WWW Document]. URL http://www.mfe.govt.nz/publications/waste/life-cycle- assessmentproduct-stewardship-options-mercury-containing-lamps-new-1

Moffatt, I., 2000. FORUM: THE ECOLOGICAL FOOTPRINT Ecological footprints and sustainable development. Ecol. Econ. 32, 359-362. doi:10.1016/S09218009(99)00154-8

Mongelli, I., Neuwahl, F., Rueda-Cantuche, J.M., 2010. Integrating a household demand system in the input-output framework. methodological aspects and modelling implications. Econ. Syst. Res. 22, 201-222. doi:10.1080/09535314.2010.501428

Nakamura, S., Nansai, K., 2016. Input--Output and Hybrid LCA, in: Finkbeiner, M. (Ed.), Special Types of Life Cycle Assessment. Springer Netherlands, Dordrecht, pp. 219291. doi:10.1007/978-94-017-7610-3_6

Nash, H.A., 2009. The European Commission's sustainable consumption and production and sustainable industrial policy action plan. J. Clean. Prod. 17, 496-498. doi:10.1016/j.jclepro.2008.08.020

National Geographic, 2018. The Development of Agriculture. The Farming Revolution [WWW Document]. URL https:/genographic.nationalgeographic.com/development-of-agriculture/

National Research Council, 1992. Human Consequences and Responses, in: Global Environmental Change: Understanding the Human Dimensions. Washington.

Nations, U., 2010. Introduction to the Millennium Development Goals. World Dev. 8184. 
Input-Output Analysis for the quantification of the Environmental Footprint. Case studies in Spain

Nicolai, S., Hoy, C., Berliner, T., Aedy, T., 2015. Projecting progress Reaching the SDGs by 2030 .

OCE, 2016. El carbón en España en 201619.

Olawumi, T.O., Chan, D.W.M., 2018. A scientometric review of global research on sustainability and sustainable development. J. Clean. Prod. 183, 231-250. doi:10.1016/j.jclepro.2018.02.162

Onat, N.C., Kucukvar, M., Tatari, O., 2014. Scope-based carbon footprint analysis of U.S. residential and commercial buildings: An input-output hybrid life cycle assessment approach. Build. Environ. 72, 53-62. doi:10.1016/j.buildenv.2013.10.009

Ottelin, J., Heinonen, J., Junnila, S., 2018. Carbon footprint trends of metropolitan residents in Finland: How strong mitigation policies affect different urban zones. J. Clean. Prod. 170, 1523-1535. doi:10.1016/j.jclepro.2017.09.204

Pachauri, S., Spreng, D., 2002. Pachauri(2002)_Direct and indirect energy requirements of households in India.pdf 30, 511-523.

Pang, M., Zhang, L., Wang, C., Liu, G., 2015. Environmental life cycle assessment of a small hydropower plant in China. Int. J. Life Cycle Assess. 20, 796-806. doi:10.1007/s11367-015-0878-7

Park, H.C., Heo, E., 2007. The direct and indirect household energy requirements in the Republic of Korea from 1980 to 2000-An input-output analysis. Energy Policy 35, 2839-2851. doi:10.1016/j.enpol.2006.10.002

Pascale, A., Urmee, T., Moore, A., 2011. Life cycle assessment of a community hydroelectric power system in rural Thailand. Renew. Energy 36, 2799-2808. doi:10.1016/j.renene.2011.04.023

Pelenc, J., Ballet, J., 2015. Weak Sustainability versus Strong Sustainability. Brief for GSDR 2015. United Nations (UN) 1-4. doi:10.4337/9781781007082

Pfister, S., Koehler, A., Hellweg, S., 2009. Assessing the Environmental Impacts of Freshwater Consumption in LCA. Environ. Sci. Technol. 43, 4098-4104. doi:10.1021/es802423e

Posch, M., Seppälä, J., Hettelingh, J.-P., Johansson, M., Margni, M., Jolliet, O., 2008. The role of atmospheric dispersion models and ecosystem sensitivity in the determination of characterisation factors for acidifying and eutrophying emissions in LCIA. Int. J. Life Cycle Assess. 477-486.

Pothen, F., Tovar Reaños, M.A., 2018. The Distribution of Material Footprints in Germany. Ecol. Econ. 153, 237-251. doi:https://doi.org/10.1016/j.ecolecon.2018.06.001

Qinfen, Z., Bryan, K., L., M.H., Jingchun, F., 2007. Life-Cycle Inventory of Energy Use and Greenhouse Gas Emissions for Two Hydropower Projects in China. J. Infrastruct. Syst. 13, 271-279. doi:10.1061/(ASCE)1076-0342(2007)13:4(271)

Real Instituto Elcano, European Parliament, European Commission, 2006. 20 Years of Spain in the European Union (1986-2006).

Reutter, B., Lant, P., Reynolds, C., Lane, J., 2017. Food waste consequences: Environmentally extended input-output as a framework for analysis. J. Clean. Prod. 
153, 506-514. doi:10.1016/j.jclepro.2016.09.104

Rockström, J., Steffen, W., Noone, K., Persson, Å., Chapin, F.S., Lambin, E.F., Lenton, T.M., Scheffer, M., Folke, C., Schellnhuber, H.J., Nykvist, B., de Wit, C.A., Hughes, T., van der Leeuw, S., Rodhe, H., Sörlin, S., Snyder, P.K., Costanza, R., Svedin, U., Falkenmark, M., Karlberg, L., Corell, R.W., Fabry, V.J., Hansen, J., Walker, B., Liverman, D., Richardson, K., Crutzen, P., Foley, J.A., 2009. Planetary Boundaries: Exploring the Safe Operating Space for Humanity. Nature 461, 472-475. doi: $10.1038 / 461472 \mathrm{a}$

Rosenbaum, R., Bachmann, T., Swirsky Gold, L., Huijbregts, M., Jolliet, O., Juraske, R., Koehler, A., Larsen, H., MacLeod, M., Margni, M., E McKone, T., Payet, J., Schuhmacher, M., Van de meent, D., Hauschild, M., 2008. USEtox - The UNEPSETAC toxicity model: recommended characterisation factors for human toxicity and freshwater ecotoxicity in Life Cycle Impact Assessment. Int. J. Life Cycle Assess. 13, 532-546. doi:10.1007/s11367-008-0038-4

Saidi, K., Hammami, S., 2015. The impact of CO2 emissions and economic growth on energy consumption in 58 countries. Energy Reports 1, 62-70. doi:https://doi.org/10.1016/j.egyr.2015.01.003

Sala, S., Benini, L., Castellani, V., Vidal-Legaz, B., Pant, R., 2016. Environmental Footprint - Update of Life Cycle Impact Assessment methods 1-114.

Sala, S., Vasta, A., Mancini, L., Dewulf, J., Rosenbaum, E., 2015. Social Life Cycle Assessment. doi:10.1007/978-981-287-296-8

Schneider, L., 2014. A comprehensive approach to model abiotic resource provision capbility in the context of sustainable development. Fak. III Prozesswissenschaften Dr.-Ing.

Selin, H., VanDeveer, S.D., 2015. EU Environmental Policy Making and Implementation: Changing Processes and Mixed Outcomes. 14th Bienn. Conf. Eur. Union Stud. Assoc. 1-28.

Seppälä, J., Posch, M., J., M., Hettelingh, J.P., 2006. Country-Dependent Characterisation Factors for Acidification and Terrestrial Eutrophication Based on Accumulated Exceedance as an Impact Category Indicator. Int. J. Life Cycle Assess. 11, 403-416.

SETAC, 2018. SETAC [WWW Document]. URL https://www.setac.org/page/AboutSETAC (accessed 3.5.18).

Sgrosso, R., 2018. Proyecto de reconstrucción de la presa de Robledo de Chavela (Reconstruction project of Robledo de Chavela dam). Universidad Politécnica de Madrid.

Song, C., Gardner, K.H., Klein, S.J.W., Pereira, S., Mo, W., 2018. Cradle-to-grave greenhouse gas emissions from dams in the United States of America. Renew. Sustain. Energy Rev. 90, 945-956. doi:10.1016/j.rser.2018.04.014

Sonnemann, G., Gemechu, E.D., Remmen, A., Frydendal, J., Jensen, A.A., 2015. Life Cycle Management: Implementing Sustainability in Business Practice 7-22. doi:10.1007/978-94-017-7221-1

Soode-Schimonsky, E., Richter, K., Weber-Blaschke, G., 2017. Product environmental footprint of strawberries: Case studies in Estonia and Germany. J. Environ. Manage. 
Input-Output Analysis for the quantification of the Environmental Footprint. Case studies in Spain

203, 564-577. doi:10.1016/j.jenvman.2017.03.090

Spadaro, J. V., Rabl, A., 2004. The RiskPoll software, version 1.051 [WWW Document]. URL www.arirabl.com (accessed 6.11.18).

Stadler, K., Wood, R., Bulavskaya, T., Södersten, C.-J., Simas, M., Schmidt, S., Usubiaga, A., Acosta-Fernández, J., Kuenen, J., Bruckner, M., Giljum, S., Lutter, S., Merciai, S., Schmidt, J.H., Theurl, M.C., Plutzar, C., Kastner, T., Eisenmenger, N., Erb, K.-H., de Koning, A., Tukker, A., 2018. EXIOBASE 3: Developing a Time Series of Detailed Environmentally Extended Multi-Regional Input-Output Tables. J. Ind. Ecol. 00. doi:10.1111/jiec.12715

Steen-Olsen, K., Wood, R., Hertwich, E.G., 2016. The Carbon Footprint of Norwegian Household Consumption 1999-2012. J. Ind. Ecol. 20, 582-592. doi:10.1111/jiec.12405

Steffen, W., Rockström, J., Richardson, K., Lenton, T.M., Folke, C., Liverman, D., 2018. Trajectories of the Earth System in the Anthropocene 1-8. doi:10.1073/pnas.1810141115

Steinmann, Z.J.N., Schipper, A.M., Stadler, K., Wood, R., de Koning, A., Tukker, A., Huijbregts, M.A.J., 2018. Headline Environmental Indicators Revisited with the Global Multi-Regional Input-Output Database EXIOBASE. J. Ind. Ecol. 22, 565573. doi:10.1111/jiec. 12694

Struijs, J., Beusen, A., van Jaarsveld, H., Huijbregts, M.A.J., 2009. Aquatic Eutrophication., in: Chapter 6 Goedkoop, M., Heijungs, R., Huijbregts, M.A.J., De Schryver, A., Struijs, J., Van Zelm, R. (2009) ReCiPe 2008 A Life Cycle Impact Assessment Method Which Comprises Harmonised Category Indicators at the Midpoint and the Endpoint Level. First Edit.

Suh, S., 2004. Functions, commodities and environmental impacts in an ecologicaleconomic model. Ecol. Econ. 48, 451-467. doi:10.1016/j.ecolecon.2005.08.008

Suh, S., Huppes, G., 2005. Methods for Life Cycle Inventory of a product 13. doi:10.1016/j.jclepro.2003.04.001

Suwanit, W., Gheewala, S.H., 2011. Life cycle assessment of mini-hydropower plants in Thailand. Int. J. Life Cycle Assess. 16, 849-858. doi:10.1007/s11367-011-0311-9

Tarne, P., Lehmann, A., Finkbeiner, M., 2018. A comparison of Multi-Regional InputOutput databases regarding transaction structure and supply chain analysis. J. Clean. Prod. 196, 1486-1500. doi:10.1016/j.jclepro.2018.06.082

Teixeira, R.F.M., De Souza, D.M., Curran, M.P., Antón, A., Michelsen, O., Milá I Canals, L., 2016. Towards consensus on land use impacts on biodiversity in LCA: UNEP/SETAC Life Cycle Initiative preliminary recommendations based on expert contributions. J. Clean. Prod. 112, 4283-4287. doi:10.1016/j.jclepro.2015.07.118

The Blue Angel, 2018. The Blue Angel protects the climate [WWW Document]. URL https://www.blauer-engel.de/en (accessed 1.3.17).

The Nordic Council, 2014. Goals and Principles for the Nordic Ecolabel ( the Swan ) 15.

Tian, X., Geng, Y., Dong, H., Dong, L., Fujita, T., Wang, Y., Zhao, H., Wu, R., Liu, Z., 
Sun, L., 2016. Regional household carbon footprint in China: A case of Liaoning province. J. Clean. Prod. 114, 401-411. doi:10.1016/j.jclepro.2015.05.097

Tian, X., Sarkis, J., Geng, Y., Qian, Y., Gao, C., Bleischwitz, R., Xu, Y., 2018. Evolution of China's water footprint and virtual water trade: A global trade assessment. Environ. Int. 121, 178-188. doi:https://doi.org/10.1016/j.envint.2018.09.011

Trujillo, C.M., Long, T.M., 2018. Document co-citation analysis to enhance transdisciplinary research. Sci. Adv. 4, e1701130. doi:10.1126/sciadv.1701130

Tsalis, T., Avramidou, A., Nikolaou, I.E., 2017. A social LCA framework to assess the corporate social profile of companies: Insights from a case study. J. Clean. Prod. 164, 1665-1676. doi:10.1016/j.jclepro.2017.07.003

Tukker, A., Bulavskaya, T., Giljum, S., de Koning, A., Lutter, S., Simas, M., Stadler, K., Wood, R., 2014. The Global Resource Footprint of Nations: Carbon, water, land and materials embodied in trade and final consumption calculated with EXIOBASE 2.1, Carbon, water, land and materials embodied in trade and final consumption calculated with EXIOBASE.

United Nations, 2017. EGM on Strategies for Eradicating Poverty to achieve Sustainable Development for All [WWW Document]. URL https://www.un.org/development/desa/dspd/2017egms/poverty.html (accessed 6.6.18).

United Nations, 2015. Convention on Climate Change: Climate Agreement of Paris. 127. doi:10.1017/s0020782900004253

United Nations, 2012. United Nations Conference on Sustainable Development, Rio + 20 [WWW Document]. URL https://rio20.un.org/resolutions-more (accessed 4.3.18).

United Nations (UN), 2018. Millennium Development Goals [WWW Document]. URL http://www.un.org/millenniumgoals/ (accessed 6.6.18).

United Nations Development Programme (UNDP), 2018. Millennium Development Goals [WWW Document]. URL http://www.undp.org/content/undp/en/home/sdgoverview/mdg_goals.html (accessed 9.10.18).

United Nations Environment Programme, 2014. Managing and Conserving the Natural Resource Base for Sustained Economic and Social Development.

United Nations Framework Convention on Climate Change, 2008. Kyoto Protocol Reference Manual. United Nations Framew. Conv. Clim. Chang. 1-130. doi:10.5213/jkcs.1998.2.2.62

van Eck, N.J., Waltman, L., 2010. Software survey: VOSviewer, a computer program for bibliometric mapping. Scientometrics 84, 523-538. doi:10.1007/s11192-009-01463

Van Oers, L., Huijbregts, M.A.J., Huppes, G., de Koning, A., Suh, S., 2001. LCA normalisation factors for the Netherlands, Western Europe and the World. Int. J. Life Cycle Assess. 6, 256. doi:10.1007/BF02978785

van Zelm, R., Huijbregts, M.A.J., den Hollander, H.A., van Jaarsveld, H.A., Sauter, F.J., Struijs, J., van Wijnen, H.J., van de Meent, D., 2008. European characterization 
Input-Output Analysis for the quantification of the Environmental Footprint. Case studies in Spain

factors for human health damage of PM10 and ozone in life cycle impact assessment. Atmos. Environ. 42, 441-453. doi:10.1016/j.atmosenv.2007.09.072

Vanham, D., Hoekstra, A.Y., Bidoglio, G., 2013. Potential water saving through changes in European diets. Environ. Int. 61, 45-56. doi:10.1016/j.envint.2013.09.011

Vieira, M., 2018a. The basics of the LCA methodology [WWW Document]. URL https://www.pre-sustainability.com/sustainability-consulting/lca-methodologybasics (accessed 6.4.18).

Vieira, M., 2018b. Impact assessment in the PEF initiative [WWW Document]. URL https://www.pre-sustainability.com/news/pef-series-impact-assessment-in-the-pefapproach (accessed 4.2.18).

Vieira, M., 2018c. Product environmental footprinting - the new European standard [WWW Document]. URL https://www.pre-sustainability.com/sustainabilityconsulting/sustainable-innovation/product-environmental-footprinting (accessed 10.10.18).

Vieira, M., 2018d. Hotspot analysis in the PEF approach [WWW Document].

Wackernagel, M., Lewan, L., Hansson, C.B., 1999a. Evaluating the Use of Natural Capital with the Ecological Footprint: Applications in Sweden and Subregions. Ambio 28, 604-612.

Wackernagel, M., Onisto, L., Bello, P., Linares, a C., Falfan, I.S.L., Garcia, J.M., Guerrero, a I.S., Guerrero, M.G.S., 1999. National natural capital accounting with the ecological footrpint concept. Ecol. Econ. 29, 375-390.

Wackernagel, M., Onisto, L., Bello, P., Linares, A.C., Lo, I.S., Sua, A.I., 1999b. National natural capital accounting with the ecological footprint concept 29, 375-390.

Wackernagel, M., Rees, W.E., 1996. Our Ecological Footprint. New Society Publishers, Philadelphia.

Wahba, S.M., Scott, K., Steinberger, J.K., 2018. Analyzing Egypt's water footprint based on trade balance and expenditure inequality. J. Clean. Prod. 198, 1526-1535. doi:https://doi.org/10.1016/j.jclepro.2018.06.266

Wahba, S.M., Scott, K., Steinberger, J.K., 2018. Analyzing Egypt's water footprint based on trade balance and expenditure inequality. J. Clean. Prod. 198, 1526-1535. doi:10.1016/j.jclepro.2018.06.266

Walras, L., 1874. Éléments d'économie politique pure, ou, Théorie de la richesse sociale.

Water footprint Network, 2018. Water footprint [WWW Document]. URL https://waterfootprint.org/en/water-footprint/ (accessed 10.12.18).

Weber, C.L., Matthews, H.S., 2008. Quantifying the global and distributional aspects of American household carbon footprint. Ecol. Econ. 66, 379-391. doi:10.1016/j.ecolecon.2007.09.021

Weidema, B.P., Thrane, M., Christensen, P., Schmidt, J., Løkke, S., 2008. Carbon footprint: A catalyst for life cycle assessment? J. Ind. Ecol. 12, 3-6. doi:10.1111/j.1530-9290.2008.00005.x

Wiedmann, T., Minx, J., 2008. A Definition of "Carbon Footprint." Science (80-. ). 1, 1- 


\section{1. doi:10.1088/978-0-750-31040-6}

Wiedmann, T., Wilting, H.C., Lenzen, M., Lutter, S., Palm, V., 2011. Quo Vadis MRIO? Methodological, data and institutional requirements for multi-region input-output analysis. Ecol. Econ. 70, 1937-1945. doi:10.1016/j.ecolecon.2011.06.014

WMO, 1999. Scientific Assessment of Ozone Depletion: 1998. Global Ozone Research and Monitoring Project - Report No. 44. Geneva.

Wolf, M.-A., Pant, R., Chomkhamsri, K., Sala, S., Pennington, D., 2012. The International Reference Life Cycle Data System (ILCD) Handbook, European Commission. JRC references reports. doi:10.2788/85727

Wood, R., Dey, C.J., 2009. Australia's carbon footprint. Econ. Syst. Res. 21, 243-266. doi:10.1080/09535310903541397

Wood, R., Stadler, K., Bulavskaya, T., Lutter, S., Giljum, S., de Koning, A., Kuenen, J., Schütz, H., Acosta-Fernández, J., Usubiaga, A., Simas, M., Ivanova, O., Weinzettel, J., Schmidt, J.H., Merciai, S., Tukker, A., 2015. Global sustainability accountingdeveloping EXIOBASE for multi-regional footprint analysis. Sustain. 7, 138-163. doi:10.3390/su7010138

$\mathrm{Wu}, \mathrm{Y}$. yu, Ma, H. wen, 2018. Analysis of strategic environmental assessment in Taiwan energy policy and potential for integration with life cycle assessment. Environ. Impact Assess. Rev. 71, 1-11. doi:10.1016/j.eiar.2018.03.005

Xing, Y.-F., Xu, Y.-H., Shi, M.-H., Lian, Y.-X., 2016. The impact of PM2.5 on the human respiratory system. J. Thorac. Dis. 8, E69-E74. doi:10.3978/j.issn.20721439.2016.01.19

Yang, S., Chen, B., Wakeel, M., Hayat, T., Alsaedi, A., Ahmad, B., 2018. PM2.5 footprint of household energy consumption. Appl. Energy 227, 375-383. doi:https://doi.org/10.1016/j.apenergy.2017.11.048

Zafrilla, J.E., Cadarso, M.-A., Monsalve, F., de la Rua, C., 2014. How carbon-friendly is nuclear energy? A hybrid MRIO-LCA model of a Spanish facility. Environ. Sci. Technol. 48, 14103-14111. doi:10.1021/es503352s

Zalasiewicz, J., Waters, C., Wolfe, A., Barnosky, A., Cearreta, A., Edgeworth, M., Ellis, E., Fairchild, I., Gradstein, F., Grinevald, J., Haff, P., Head, M., Ivar do Sul, J., Jeandel, C., Leinfelder, R., McNeill, J., Oreskes, N., Poirier, C., Revkin, A., Richter, D. deB., Steffen, W., Summerhayes, C., Syvitski, J.M., Vidas, D., Wagreich, M., Wing, S., Williams, M., 2017. Making the case for a formal Anthropocene Epoch: an analysis of ongoing critiques. Newsletters Stratigr. 50, 205-226. doi:10.1127/nos/2017/0385

Zeng, Z., Liu, J., Koeneman, P.H., Zarate, E., Hoekstra, A.Y., 2012. Assessing water footprint at river basin level : a case study for the Heihe River Basin in northwest China 2771-2781. doi:10.5194/hess-16-2771-2012

Zhang, S., Pang, B., Zhang, Z., 2015. Carbon footprint analysis of two different types of hydropower schemes: Comparing earth-rockfill dams and concrete gravity dams using hybrid life cycle assessment. J. Clean. Prod. 103, 854-862. doi:10.1016/j.jclepro.2014.06.053

Zhang, Y., Huang, K., Yu, Y., Yang, B., 2017. Mapping of water footprint research: A 
bibliometric analysis during 2006-2015. J. Clean. Prod. 149, 70-79. doi:10.1016/j.jclepro.2017.02.067

Zhang, Y.J., Bian, X.J., Tan, W., Song, J., 2017. The indirect energy consumption and CO2emission caused by household consumption in China: an analysis based on the input-output method. J. Clean. Prod. 163, 69-83. doi:10.1016/j.jclepro.2015.08.044

Zhao, G., Gao, C., Xie, R., Lai, M., Yang, L., 2018. Provincial water footprint in China and its critical path. Ecol. Indic. doi:https://doi.org/10.1016/j.ecolind.2018.06.058 